\title{
FOLKEVALGT OG \\ POLITISK LEDER
}

ASB $\ \varnothing R N$ RøISELAND OG SIGNY IRENE VABO (RED.)

NOASP 

Asbjørn Røiseland og Signy Irene Vabo (red.)

\section{Folkevalgt og politisk leder}


(C) 2020 Asbjørn Røiseland, Signy Irene Vabo, Tina Øllgaard Bentzen, Espen Leirset, Christian Lo, Eva Sørensen, Jacob Torfing og Marte Winsvold.

Dette verket omfattes av bestemmelsene i Lov om opphavsretten til åndsverk m.v. av 1961. Verket utgis Open Access under betingelsene i Creative Commons-lisensen CC BY-ND 4.0 (https://creativecommons.org/licenses/by-nd/4.0/). Denne tillater tredjepart å kopiere, distribuere og spre verket i hvilket som helst medium eller format under betingelse av korrekt kreditering og at en lenke til lisensen er oppgitt. Lisensen tillater ingen bearbeidelser.

Boka er utgitt med støtte fra Nord universitet. Forskningsprosjektet «Political leadership in local councils» er finansiert av Norges forskningsråd (prosjekt nr. 254781).

ISBN trykt bok: 978-82-02-67918-7

ISBN PDF: 978-82-02-65231-9

ISBN EPUB: 978-82-02-67915-6

ISBN HTML: 978-82-02-67916-3

ISBN XML: 978-82-02-67917-0

DOI: https://doi.org/10.23865/noasp. 80

Dette er en fagfellevurdert antologi. I tillegg til seks vitenskapelige artikler inneholder boken noen kortere tekster, intervjuer og eksempler. Disse er markert med grå marg og er ikke fagfellevurderte.

Omslagsdesign: Cappelen Damm AS

Cappelen Damm Akademisk/NOASP

noasp@cappelendamm.no 


\section{Forord}

Vi som har skrevet denne boken, har arbeidet sammen om forskningsprosjektet «Politisk lederskap i kommunestyret. En komparativ studie av Norge og Danmark», finansiert av Norges forskningsråd (prosjekt nr. 254781). Prosjektet ble avsluttet i desember 2019, og prosjektperioden sammenfalt i tid med både gjennomføringen av kommunereformen og revisjonen av kommuneloven. Disse endringene har satt politisk organisering og de folkevalgtes rolle på dagsordenen. Mange kommuner har nylig vært gjennom grundige og omfattende diskusjoner, både om det politisk-administrative systemet og om innbyggerdeltakelse. Vi ønsker og håper at denne boken kan inspirere til en vedvarende diskusjon om politisk lederskap og demokrati.

Boken er skrevet med tanke på flere målgrupper. Det er en fagbok som vi håper vil bli lest av forskerkollegaer og studenter som er opptatt av politisk organisering og politisk lederskap. Men i tillegg har vi en ambisjon om å nå ut til norske kommunepolitikere, og vi har derfor lagt stor vekt på praktiske eksempler og illustrasjoner.

Hvem norske kommunepolitikere er, og hvordan de fungerer, handler ikke bare om hvilke personer som rekrutteres inn i politikken, og hvilke saker de står for. Det handler også om det politiske og administrative systemet som politikerne skal fungere innenfor. Vi mener at det er et kontinuerlig behov for å diskutere rammebetingelsene for politisk lederskap i norske kommuner. På nasjonalt nivå handler dette om blant annet lovgivning og forskrifter som regulerer kommunesektoren. Men slike diskusjoner hører ikke minst hjemme i de enkelte kommuner og deres kommunestyrer. Et viktig budskap i denne boken er at det finnes et lokalt handlingsrom der lokale folkevalgte kan gjøre endringer for å styrke demokratiet og det politiske lederskapet. Boken er organisert rundt fire sentrale paradokser som vi mener kan være nyttige innganger for å diskutere slike endringer.

Boken bygger på data hentet inn i norske og danske kommuner, blant annet gjennom det omtalte forskningsprosjektet. Vi vil benytte 
anledningen til å takke alle som har bidratt som informanter i prosjektet, både i timelange intervjuer og i samtaler med forskerne samt ved å svare på spørreskjemaer. Uten denne innsatsen ville det aldri ha blitt noen bok. Som redaktører vil vi også takke våre gode kollegaer som har bidratt i boken og sørget for å gjøre den best mulig gjennom interessante og konstruktive faglige diskusjoner. Vi vil også takke vår redaktør i Cappelen Damm Akademisk, Simon Aase, samt Marte Ericsson Ryste, for en ryddig og effektiv utgivelsesprosess.

Dette er en Open Access-bok, noe som innebærer at den ikke selges, men gis bort til leseren. Men det å produsere en slik bok er selvfølgelig ikke gratis. Det er Open Access-fondet ved Nord universitet som har gjort utgivelsen mulig, og vi retter derfor stor takk til Nord universitet for bidraget til å gjøre forskningen vår tilgjengelig på denne måten.

Oslo, 12. februar 2020 


\section{Innhold}

KAPITEL 1

Folkevalgt og politisk leder

Som to dråper vann? Norske og danske kommuner

KAPITTEL 2

Konfliktparadokset. Samarbeid og konflikt i kommunepolitikken

Kompromiss er ofte den beste løsningen

KAPITTEL 3

Administrasjonsparadokset. Farvel til timeglassmodellen?

Om timeglassmodellen - og sanden som renner utenfor

KAPITTEL 4

Åpenhetsparadokset. Åpne eller lukkede møter i lokalpolitikken?

95

Strengere enn på Stortinget

KAPITTEL 5

Demokratiparadokset. Hvordan styre et folk som skal styre seg selv? 120

Gikk imot folkeavstemning

KAPITTEL 6

Refleksjoner rundt paradokser, lederskap og læring 146

Alle politikere er ledere!

Eksempel på folkevalgtprogram rettet mot politisk lederskap 



\title{
KAPITTEL 1
}

\section{Folkevalgt og politisk leder}

\author{
Asbjørn Røiseland
}

Nord universitet, OsloMet

Signy Irene Vabo

Universitetet i Oslo

\section{Eva Sørensen}

Roskilde universitet

\section{Jacob Torfing}

Roskilde universitet

\begin{abstract}
This chapter introduces the book. In the first part, we discuss different meanings of "political leadership", arguing that political leadership should be understood as three interrelated functions: Identifying problems, give direction and mobilizing support. After discussing important theoretical trends in political leadership research, the chapter sums up relevant former Norwegian research in the field. In the latter part, the chapter introduces four paradoxes that will structure the book. The four paradoxes are related to "conflict", "administration", "openness" and "democracy". The latter part also explains the empirical strategy, and why we have chosen to compare Norwegian and Danish local governments. In a brief and subsequent chapter, we point to some interesting similarities and differences between Norway and Denmark.
\end{abstract}

Keywords: political leadership, local government, paradox 


\section{Introduksjon}

Et demokrati har behov for politiske ledere som kan finne løsninger på viktige utfordringer, og som evner å skissere og skape entusiasme for optimistiske fremtidsbilder. Politisk lederskap etterspørres aller tydeligst ved akutte kriser, men vil også være viktig i mer normale situasjoner, for eksempel når nye problemer trenger en løsning, eller når det oppstår behov for større omprioriteringer.

Selv om vi kan være enige om at politisk lederskap er viktig, er det likevel ikke gitt hva dette skal bety i praksis i alle mulige situasjoner. Kommunereformen kan illustrere poenget. I oppstarten av reformen uttalte kommunal- og moderniseringsministeren følgende: «Jeg har tillit til at dere nå viser lokalt lederskap og finner de beste løsningene for innbyggerne. Erfaringer tilsier at de beste løsningene oppnås gjennom gode lokale prosesser» (Jan Tore Sanner [2014] i brev til de folkevalgte i kommunestyrene). Men selv om regjeringen la til grunn at kommunestyrerepresentantene skulle ta beslutningen om kommunesammenslåing, så hadde mange andre et alternativt syn, nemlig at innbyggerne selv skulle bestemme dette. Derfor ble det avholdt folkeavstemninger i over 200 kommuner. I de aller fleste tilfellene fulgte kommunestyret det rådet folkeavstemningen ga, også i de tilfellene der kommunestyret $\mathrm{i}$ utgangspunktet hadde et annet syn.

Argumentet om at innbyggerne selv skal bestemme, som i eksemplet over, illustrerer godt det paradoksale ved politisk lederskap i et representativt demokrati. På den ene siden bygger styreformen demokrati på ideen om det suverene folk, der alle innbyggerne i prinsippet skal ha like mye å si. Men i et representativt demokrati velger folket sine representanter i frie valg. Paradokset oppstår fordi den grunnleggende likhetstanken, som ligger i den demokratiske forestillingen om det suverene folk, strider mot tanken om et tydelig og sterkt politisk lederskap.

Det er et grunnleggende spørsmål hvordan vi i det hele tatt kan forsvare at de folkevalgte som politiske ledere inntar en overordnet styringsrolle overfor innbyggerne. Logikken i det representative demokratiet er jo 
at innbyggerne, gjennom muligheten for å stemme, overlater til et flertall av de valgte representantene å fatte bindende beslutninger på vegne av kollektivet. Normativt sett vil noen argumentere for at politisk representasjon er en nest best løsning, siden den beste løsningen, nemlig direkte deltakelse, vil være vanskelig å gjennomføre fullt ut i et moderne demokrati. Andre vil argumentere for at representativt demokrati er det beste. Utvelgelsen av representanter sikrer at de som nyter mest tillit blant velgerne, blir gitt ansvaret for å fatte kollektive beslutninger (Esaiasson, 2010; Hartley \& Benington, 2011; Hendriks \& Karsten, 2014).

Forholdet mellom politisk lederskap og ideen om det suverene folk kan utlegges som et paradoks, som vi senere i boken skal omtale og analysere som «demokratiparadokset». I tillegg til dette paradokset er boken organisert rundt diskusjonen av tre andre paradokser knyttet til forholdet mellom politisk lederskap og henholdsvis politiske konflikter, administrasjon og åpenhet. De fire paradoksene og bokens innhold for øvrig vil bli nærmere presentert mot slutten av dette innledningskapitlet.

Bokens utgangspunkt og overordnede perspektiv er at alle folkevalgte er politiske ledere. Det å være valgt er i seg selv en lederfunksjon, selv om det selvfølgelig er stor forskjell på utøvelsen av dette lederskapet hos en ordfører kontra hos en menig representant i kommunestyret.

Blant de mange oppfatninger om hva politisk lederskap innebærer, som vi kommer tilbake til, tar vi i denne boken utgangspunkt i betraktningen hos Charles Tucker (1995). Han er opptatt av lederskapets tre ulike funksjoner: å «forstå problemer», å «foreslå løsninger» og å «mobilisere støtte og handlekraft» (se figur 1.1). Når de politiske lederne skal tilby en problemdiagnose, så innebærer dette at de skal omtale hendelser, utviklingstrekk og omstendigheter som utfordrer det politiske fellesskapet, og vise hvordan disse kaller på politisk handling. Politisk lederskap innebærer blant annet å sette dagsorden og derigjennom bestemme hvilket sett av politiske spørsmål eller saker som fortjener politisk oppmerksomhet. Problemdiagnosen skapes gjennom at politiske ledere tillegger bestemte forhold mening og gjør dem til gjenstand for politisk debatt. Den politiske ledelsen er med andre ord ansvarlig for å definere situasjonen. 


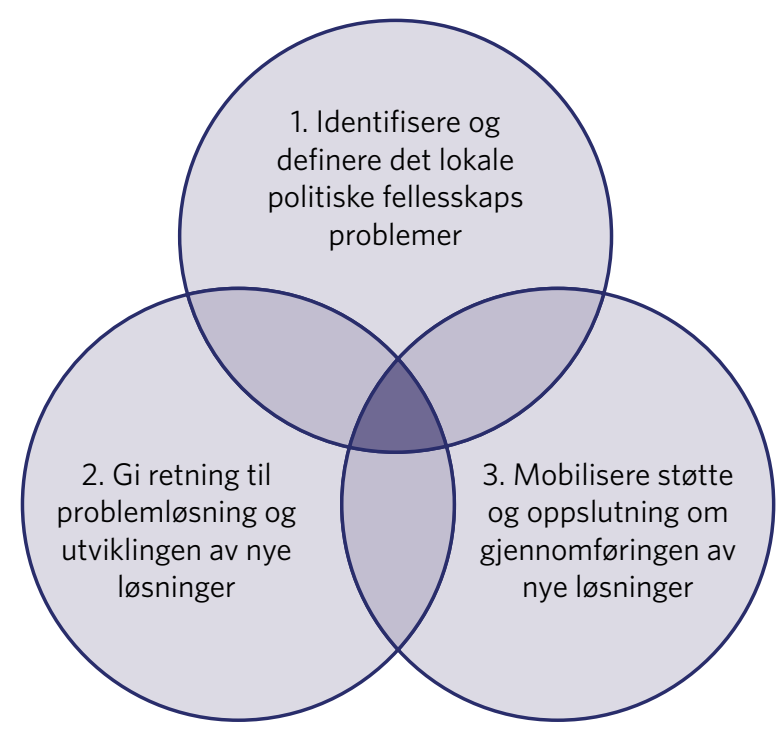

Figur 1.1 Tre funksjoner i lokalpolitisk lederskap (etter Tucker, 1995)

Den andre funksjonen politiske ledere bør ivareta, går ut på å arbeide frem handlingsmuligheter. De skal tilby politiske strategier og programmer som angir hva som kan og bør gjøres for at problemene skal løses, og for at samfunnet skal utvikle seg i den retningen problemdefinisjonen tilsier. Den politiske ledelsen skal presentere mulige handlingsalternativer, peke ut de som foretrekkes, og vise konsekvensene av disse. Lederskap innebærer med andre ord å utforme den konkrete politikken.

Politisk lederskap innebærer også å mobilisere det politiske fellesskapet i betydningen folket, borgerne eller velgerne. Politiske ledere har behov for at folket følger dem. Vellykket gjennomføring av valgprogrammer, tiltak eller liknende forutsetter oppslutning om både problemdefinisjonen og den valgte løsningen. Mobilisering og aktiv støtte er spesielt viktig dersom politikernes løsningsforslag forutsetter at borgerne skal bidra til at disse løsningene blir realisert.

Denne teoretiske forståelsen av politisk lederskap går langt ut over det å fatte politiske beslutninger. Tar vi utgangspunkt i stegene i politikkutformingsprosessen, slik denne er illustrert i figur 1.2, ser vi at de funksjonene som inngår i politisk lederskap, omfatter så vel det å ta initiativ til saker som å sette den politiske agendaen og utforme politikk. 

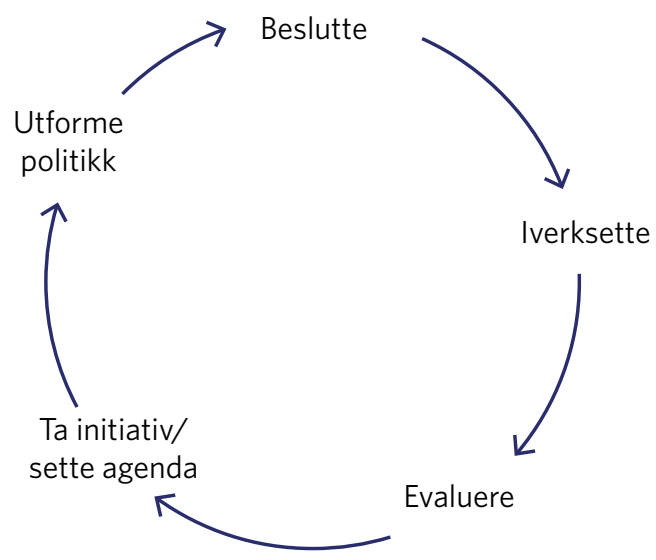

Evaluere

Figur 1.2 Stegene i politikkutformingsprosessen

Denne måten å beskrive politikkutformingsprosessen på er hentet fra litteraturen om offentlig politikk (se f.eks. Birkland, 2016, s. 28; Dye, 2017, s. 11). Stegene i prosessen blir beskrevet på litt ulike måter, men poenget vi ønsker å legge vekt på, er de folkevalgtes sentrale rolle i de innledende fasene av politikkutformingen. Til tross for at folkevalgte har en viktig rolle i å fortolke lokale problemer og definere handlingsalternativer, så har denne funksjonen i liten grad vært på den offisielle dagsordenen. Dette var eksempelvis ikke del av diskusjonen da kommuneloven ble endret i 1992. Som vi skal se i kapittel 3, var det viktigste for det lovforberedende utvalget å rydde opp i forholdet mellom politikk og administrasjon gjennom å skille beslutningsfasen fra iverksettingsfasen (NOU 1990: 13). Som kjent ble også kontrollutvalgene innført, med vekt på politikernes mulighet for å kontrollere kommunedirektørens ${ }^{1}$ (rådmannens) og administrasjonens iverksetting av politiske vedtak. Heller ikke i den nye kommunelovens forarbeider finner vi noen diskusjon rundt eller problematisering av hvordan lokal politikk blir til. Det vises til forskning som trekker i retning av at norske lokalpolitikere opplever manglende innflytelse (NOU 2016: 4, s. 78). Dette forklares dels som et resultat av hvor mye makt og myndighet som ligger i statlige lover og regler, og dels

1 I denne boken benyttes gjennomgående den kjønnsnøytrale betegnelsen «kommunedirektør», som ble introdusert med kommuneloven av 2018, om rådmann eller administrasjonssjef uavhengig av hvilken betegnelse som er benyttet i den opprinnelige teksten. 
av hvor mye makt og myndighet kommunestyret har delegert til kommunedirektøren. Men når forholdet mellom politikk og administrasjon diskuteres, er det også her politikernes beslutningsmyndighet som er utvalgets omdreiningspunkt (NOU 2016: 4, kapittel 8.6).

\section{Politisk lederskap, makt og institusjoner}

Styrken i det politiske lederskapet er tett forbundet med evnen til å utøve makt. Hva det innebærer, er imidlertid ikke gitt. I den politiske lederskapsteorien diskuteres hva det vil si å utøve makt, og hvilken form for maktutøvelse politiske ledere utøver (Tucker, 1995; Keohane, 2014). I den daglige samfunnsdebatten er det en tendens til å knytte politiske lederes maktutøvelse til det vi kan kalle beslutningsmakt. Det antas at politisk lederskap er tett forbundet med politikernes formelle posisjon $\mathrm{i}$ de politiske beslutningsprosessene, og med politikernes evne til å anvende denne formelle ressursen når konkrete politiske beslutninger skal fattes. Denne reaktive forståelsen av politiske lederskap overser at lederskap til sjuende og sist handler om å vise vei og få noe til å skje (Burns, 1998; Nye, 2008). I lys av et slikt «produktivt maktperspektiv» avgjøres det politiske lederskapets styrke av ledernes evne til å mobilisere det politiske fellesskapets ressurser og energi for å forme konkrete resultater.

Synet på makt i utøvelsen av politisk lederskap har direkte konsekvenser for hvordan vi tenker om institusjoner som betingelse for politikernes utøvelse av lederskap. Med institusjoner forstår vi både formelle strukturer og uformelle normer som setter rammer for hvordan politiske og administrative aktører kan opptre i det politiske systemet. I land med presidentstyre, for eksempel, er det konstitusjonen, lovvedtak eller sedvane som setter rammene for presidentens makt og posisjon. Tilsvarende gjelder for ordførere i ulike land, der en eller annen form for kommunelov presiserer slike rammer, men hvor også mer uformelle normer og tradisjoner kan spille en rolle. Politiske institusjoner spiller en avgjørende rolle for det politiske lederskapets styrke, i og med at det både muliggjør og begrenser politisk lederskap (Elgie, 2014; Helms, 2014). Institusjoner muliggjør politisk lederskap i den forstand at de skaper posisjoner der politiske aktører effektivt og legitimt kan utøve lederskap. Politiske 
institusjoner legger samtidig begrensninger for lederskapet. Institusjoner setter rammer for politikernes maktutøvelse gjennom å regulere, problematisere og vanskeliggjøre visse typer ledelsesatferd. At kommunedirektøren for eksempel har ansvar for at saker som legges frem for behandling i folkevalgte organer i norske kommuner, er forsvarlig utredet, kan sette grenser for de folkevalgtes mulighet for å fatte vedtak. Dette kan være positivt ved at det settes grenser for ledelsens makt, slik at risikoen for vilkårlighet og maktmisbruk blir mindre, men samtidig kan slike institusjonelle forhold gjøre det vanskelig å treffe beslutninger på tross av bred oppslutning blant politikere, administrasjon og innbyggere.

Politiske institusjoner har altså en avgjørende betydning for politikernes beslutningsmakt. De definerer den formelle politiske maktfordelingen i samfunnet og de prosedyrene som regulerer samspillet mellom politikere, mellom politikere og administrasjon, mellom politikere og innbyggere og mellom politikere på ulike nivåer. Politiske institusjoner spiller imidlertid også en betydelig rolle for politikernes handlekraft i den forstand at de på forskjellige måter understøtter politikernes bestrebelser på å sette politiske problemer på dagsordenen, utvikle robuste og bredt aksepterte løsninger på disse problemene og mobilisere det politiske fellesskapet til handling.

Samlet sett må en studie av kommunepolitikeres lederskap ta utgangspunkt i både deres beslutningsmakt og deres handlingskapasitet, og ut fra i hvilken grad institusjonelle forhold støtter opp under forskjellige former for ledelse gjennom maktutøvelse. Det er også relevant å belyse i hvilken grad politiske ledere, herunder kommunepolitikere, har mulighet for å endre eller påvirke de institusjonelle rammene slik at de i størst mulig grad støtter opp under politisk handlekraft (Helms, 2016; Sørensen, 2017).

\section{Trender i teorien om politisk lederskap}

Etter Berlinmurens fall og etableringen av en rekke nye demokratier i øst ble diskusjonen om demokratiets tilstand i de gamle og etablerte demokratiene aktualisert, og interessen for det politiske lederskapets tilstand ble fornyet. Selv om det i liten grad har vært tilfellet i Norge, har denne interessen internasjonalt noe av sin bakgrunn i en fallende tillit til 
politikere. Det er en oppfatning at politikerne har problemer med å finne gode løsninger på nåtidens store problemer, som klimaendringer, fattigdom, flyktningstrømmer og livsstilssykdommer. Men interessen skyldes også at en ny type politiske ledere vokser frem. Disse nye lederne tyr ofte til en populistisk ledelsesretorikk der etablerte politiske eliter beskrives som fiender av folket (Mudde, 2016).

Interessen for politisk lederskap er ikke bare voksende blant samfunnsdebattanter, beslutningstakere og i befolkningen, men også i høyeste grad blant forskerne (Keohane, 2014). Mange ulike aspekter knyttet til politisk lederskap diskuteres, men med tanke på temaet i denne boken er det særlig relevant å se på to utviklingstrekk: 1) En økt oppmerksomhet på den rollen som nye styringsformer spiller i utøvelsen av politisk lederskap, og 2) en tiltakende interesse for den rollen borgerne spiller for det politiske lederskapets form og innhold. Nyere politiske ledelsesteorier peker i økende grad på at politisk lederskap først og fremst handler om å skaffe seg støttespillere og velgere gjennom å forme deres politiske identitet, verdenssyn og vilje. Burns (1998) kaller denne formen for politisk lederskap for transformativ, i og med at den retter seg mot å hjelpe innbyggerne med å gjøre det klart for dem hva de trenger. For å oppnå dette benyttes gjerne myke ledelsesverktøy, som historiefortelling, relasjonsbygging og utvikling av potensielle velgeres politiske selvtillit (Nye, 2008; Helms, 2016). Harde ledelsesformer som lov- og regelstyring og styring gjennom insitamenter er også høyst relevante i moderne politisk lederskap. Men det legges vekt på at dersom disse brukes for mye, vil det lett resultere i motstand og dermed svekke det politiske lederskapet.

Forskningen på politisk lederskap er opptatt av hvordan effekten av politiske ledelsesstrategier og -redskaper avhenger av konteksten (Masciulli, Molchanov \& Knight, 2009). Det hevdes i internasjonal litteratur at et av de kontekstuelle forholdene som for alvor utfordrer forståelsen av politisk lederskap, er fremveksten av en ny politisk kultur i de gamle og veletablerte demokratiene. Innbyggerne ser ikke lenger ut til å være tilfreds med kun å spille rollen som velgere, hevdes det, og de er blitt stadig mer antiautoritære, kritiske og politisk kompetente. Når de er misfornøyd med politikernes politiske lederskap, sier de tydelig ifra (Dalton \& Welzel, 2014). Med dette som utgangspunkt har interessen for potensielle 
støttespilleres og velgernes roller i det politiske lederskapet økt. Forskere som er opptatt av hvordan politisk lederskap kan utøves i et samfunn med antiautoritære, kritiske og kompetente innbyggere, har begynt å snakke om et relasjonelt perspektiv på politisk lederskap. Denne typen lederskap må forstås som en bestemt type samspill mellom en leder og dennes støttespillere. Innenfor politisk lederskapsteori er et slikt relasjonelt perspektiv i ferd med å fortrenge oppmerksomheten omkring den enkelte lederen. De politiske ledelsesteoriene er dermed blitt mer åpne for innbyggernes og potensielle støttespilleres rolle for utøvelsen av politisk lederskap (Blondel, 1987; Sørensen, 2019; Uhl-Bien, Riggio, Lowe \& Carsten, 2014).

Selv om den nye bølgen av politiske lederskapsteorier gir mange forskjellige svar, så peker de alle på at tradisjonelle former for hierarkisk basert politisk lederskap er i utakt med en moderne demokratisk politisk kultur. I en slik kultur må «følgerne» tildeles en aktiv rolle i samfunnsstyringen. Teorier om lederskap som er inspirert av New Public Management, peker på at politiske ledere skal konsentrere seg om å tilrettelegge den overordnede samfunnsutviklingen gjennom tett dialog med administrative toppledere, og at de ellers skal gi stort rom for at individuelle innbyggere kan velge fritt mellom forskjellige tilbud (Osborne \& Gaebler, 1991). Teorier om politisk metastyring understreker på sin side behovet for at politiske ledere gir innbyggerne rom for selvbestemmelse i lokale fellesskap og nettverk (Fung \& Wright, 2003; Sørensen \& Torfing, 2016). Endelig understreker teorier om interaktivt politisk lederskap betydningen av at politiske ledere utøver sitt lederskap i tett og løpende dialog med sine støttespillere (Burns, 1998; Torfing \& Ansell, 2017; Sørensen, 2019).

\section{Forskning på politisk lederskap i norske kommuner}

Politisk lederskap er ikke noe stort og etablert forskningsfelt i Norge. Når det gjelder kommunalt nivå, skrev Larsen og Offerdal (1990) i sin tid om politisk lederskap, men da som ivaretakelse av ulike roller en lokalpolitiker kunne og burde ivareta. Så vidt vi kjenner til, finnes det kun én nyere bok (redigert av Aarsæther og Mikalsen [2015]) som tar for seg lokalpolitisk lederskap, men denne handler hovedsakelig om ordførerens 
lederskapsrolle (se også Willumsen, 2014). Det har dermed ikke tidligere vært rettet søkelys mot kommunestyrerepresentantenes lederskapsfunksjoner, slik vi gjør i denne boken.

Det betyr likevel ikke at rollen som folkevalgt i norske kommuner er ustudert i nyere tid. I det følgende skal vi gå igjennom noen av de aktuelle bidragene, som handler om temaer som ligger nær dem vi tar opp i boken, det vil si representasjon og relasjonen til innbyggerne, relasjonen til kommunedirektøren og de folkevalgtes trivsel. Som vi vil se, handler imidlertid den foreliggende litteraturen kun indirekte om å ivareta lederskapsfunksjoner slik vi har beskrevet dem over.

\section{Kommunelovprogrammet}

De endringene i politisk og administrativ organisering som fulgte av kommuneloven av 1992, ble undersøkt i et eget program i Norges forskningsråd, gjennomført i perioden 1997-2002. Når det gjaldt kommunestyrerepresentantene - som er dem vi retter mest oppmerksomhet mot i denne boken - handlet diskusjonen den gangen i hovedsak om effekter av de endringene i politisk organisering som hadde funnet sted. Spørsmålet som ble stilt, var om organisasjonsendringene styrket kommunepolitikernes stilling og dermed fikk det representative lokale demokratiet til å fungere bedre og lede til økt tillit blant folk.

De viktigste funnene fra de gjennomførte studiene oppsummeres i fire punkter av Aarsæther og Vabo (2002, s. 106-113). For det første viste det seg at ideen om en strategiorientert og overordnet styringsrolle ikke alltid var formålstjenlig. I praksis viste evalueringen av den parlamentariske modellen i Oslo og av strategiorienterte styringsmodeller i formannskapskommuner at politikerne også grep fatt i småsaker - ikke minst i kontakten med innbyggerne i kommunen. For det andre ble det pekt på at helhetsperspektivet, som ble en del av det strategiske og overordnede styringskonseptet, lett kunne føre til at behovet for spesialisering ble oversett. Spesialisering - i utvalg eller komiteer - gir politikerne informasjon og kunnskap om kommunens tjenester og oppgaver som kan være viktig i styringen av administrasjonen. Dette gjaldt ikke minst der delegasjonen til administrasjonen var omfattende. Det tredje punktet som trekkes 
frem, er partienes viktige og undervurderte rolle i kommuner med formannskapsmodell. Studiene antydet at den politiske konstitueringen av kommunestyret var minst like viktig som politisk organisasjonsmodell - parlamentarisme eller formannskapsmodell - for konfliktnivået i politikken. Det fjerde og siste punktet som ble trukket frem, var at ensidig oppmerksomhet på den strategiske politikerrollen kan ha underkommunisert de andre rollene som lokalpolitikerne spiller. Det ble blant annet argumentert med at lokalpolitikken også fungerer som arena for å forme lokale ønsker og lokale prioriteringer, og at lokale utfordringer har fått mindre plass.

\section{KS' lokaldemokratiundersøkelser}

Den mest systematiske kartleggingen av de folkevalgte og relasjonen mellom politikk og administrasjon over tid finner vi i lokaldemokratiundersøkelsene i regi av KS. Disse undersøkelsene tilbys og gjennomføres i de kommunene som ønsker det, og de er så langt gjennomført i tre runder, 2009-2010, 2014 og 2017-2018. Data samles inn fra både innbyggere og folkevalgte.

Inntrykket fra de delene av den første undersøkelsen som omhandlet politikernes rolle og relasjon til innbyggerne, gjennomført av 82 kommuner i 2009/2010, er at det store flertall av de folkevalgte opplever at de gjør nytte for seg i rollen som kommunestyrerepresentant, og at rollen er rimelig klar. Dermed er det ikke overraskende at 90 prosent sier de trives med arbeidet som folkevalgt. Også samspillet med administrasjonen fungerer i det store og hele tilfredsstillende, slik de folkevalgte ser det (Baldersheim \& Rose 2011, s. 18,21). I en sammenfattende analyse av data fra denne undersøkelsen konkluderer Baldersheim (2011) med at de folkevalgte opplever seg myndige i rollen sin, og at det langt fra er noen systemkrise som preger dagliglivet i lokalpolitikken. Men samtidig understrekes det at idyllen ikke er entydig, spesielt ikke når det gjelder hvordan de folkevalgte representerer innbyggerne. Blant annet beskrives innbyggernes tillit til de folkevalgte som positiv, men reservert (se også Winsvold (red.), 2013).

I en sammenlikning av resultatene, også fra den andre og tredje runden av lokaldemokratiundersøkelsen, gjelder det generelt at de folkevalgte er 
mer tilfreds enn innbyggerne med så å si alle sider ved lokaldemokratiet. Både innbyggerne og de folkevalgte er mest fornøyd med effektiviteten, som sier noe om kommunens evne til å levere tjenester som er i samsvar med innbyggernes behov, og om hvorvidt de folkevalgte oppfattes å ha god styring. Begge grupper er imidlertid minst fornøyd med pålitelighet, som handler om innbyggernes tillit til at de folkevalgte er redelige, og om den politiske styringen preges av likebehandling og respekt for politiske spilleregler. Spesielt er det mange som mener at de med gode personlige forbindelser i kommunen får ivaretatt sine interesser på en bedre måte. Det er altså en relativt utstrakt oppfatning at det foregår forskjellsbehandling i kommunene (Winsvold, 2019).

\section{Andre studier}

Det er enkelte studier som beskriver den norske lokalpolitikeren i forhold til andre land og noen studier går i dybden på relasjonen mellom politikerne og administrasjonen. Disse studiene tar opp ulike temaer og gir et noe blandet inntrykk av sitasjonen for lokalpolitikerne. Det er imidlertid to inntrykk fra disse forskningsresultatene som er relevante for innholdet i denne boken. Det første er den utfordringen som ligger i at kommunedirektøren og kommunens administrasjon oppfattes å ha stor innflytelse på de folkevalgte i kommunene - mange vil si for stor innflytelse. Det andre inntrykket henger nært sammen med dette, og det handler om at representantene i kommunestyret i liten grad synes å være engasjert i de første stegene i politikkutformingsprosessen, altså når det gjelder å ta initiativ til saker og sette den politiske agendaen samt å utforme de politiske valgalternativene. Inntrykket er at dette for en stor del ligger i kommunedirektørens hender og ivaretas i samråd med ordfører.

En av disse studiene (Aarsæther, Jenssen \& Røiseland, 2008; Jenssen, 2010) spør hvordan lokalpolitikere utøver de nye strategiske rollene som kom med kommuneloven av 1992, som var tenkt å styrke lokalpolitikernes innflytelse i kommunene. Her undersøkes arbeidsmåtene i forbindelse med formannskaps- og kommunestyrebehandlingen av kommunebudsjettet i to nabokommuner, i to perioder med 20 års mellomrom. Den 
viktigste konklusjonen er at arbeidsmåtene rundt budsjettbehandlingen i de to kommunene ikke skaper rom for strategiske eller visjonære debatter. Ingen av arbeidsmåtene «bidrar til at det lokalpolitiske rommet fylles med interessante debatter av noe slag», skriver Jenssen (2010, s. 230). Til tross for store variasjoner i hvordan kommunene arbeidet med budsjettet, var observerte innslag av overordnede og helhetlige diskusjoner fraværende. De folkevalgte hadde en ensidig oppmerksomhet på de pragmatiske spørsmålene omkring budsjettbalanse.

En sammenliknende studie blant kommunestyrerepresentanter i en rekke europeiske land viser til målstyring som den dominerende styringsfilosofien, der det skilles tydeligere mellom politikk og administrasjon, der politikerne forventes å opptre som strateger, og der administrasjonen skal holde seg til politisk vedtatte mål (Aars \& Offerdal, 2012). I mange land har det dessuten vært arbeidet med tiltak for å styrke det folkevalgte nivået, gjerne ved å styrke ordførerens rolle gjennom direkte valg og økt myndighet (se også Lidström et al., 2016). De folkevalgtes syn på hvordan makt og påvirkning er fordelt i kommunene varierer ikke mye mellom landene, og den reelle makten blir knyttet til dem som innehar de formelle posisjonene, som ordfører, utøvende organ (formannskap i de fleste norske kommuner) og den administrative lederen. I de aller fleste landene er det ordføreren som blir tillagt mest innflytelse. Selv om forskjellene er små, er Norge ett av de få landene som avviker her, med folkevalgte som mener at kommunedirektøren har mest å si for den kommunale aktiviteten.

Denne observasjonen underbygges av en undersøkelse av maktforholdene i kommuner i Nord-Trøndelag (Haga, Leirset \& Lillestøl, 2014). Her fremkom det at mange lokalpolitikere mener at kommunestyret har for lite makt, og at kommunedirektøren har for mye makt. Det pekes på at dette dels kan skyldes en oppfatning av at det er delegert for mye ansvar til kommunedirektørene, men også at kommunedirektørene oppfattes å gå på tvers av kommunestyrets vilje. Undersøkelsen viser at kommunedirektøren eller kommunedirektøren og ordføreren i tospann oppfattes som de sentrale aktørene ved utforming av kommunens overordnede mål. Formannskapet er også viktig, mens øvrige politiske utvalg spiller en mer marginal rolle. 


\section{Fire paradokser i diskusjonen av lokalt politisk lederskap i Norge}

Den tidligere forskningen omtalt over, bærer bud om at det finnes utfordringer knyttet til lokalpolitisk lederskap i Norge. Hvordan politisk lederskap utspiller seg i praksis, vil være påvirket av en lang rekke faktorer, for eksempel egenskaper ved aktørene selv. Det sier seg selv at folkevalgte som har mange og tunge verv, for eksempel som ordfører eller komitéeller utvalgsleder, utøver en annen type politisk lederskap enn en menig representant i et kommunestyre. Også trekk ved enkeltpersoner spiller inn på det politiske lederskapet. Men i tillegg til slike individuelle variasjoner vil også politiske kulturer og tradisjoner samt lokale og nasjonale formelle institusjonelle rammer i form av politiske reglementer, forskrifter og lovverk spille en viktig rolle. Med en så variert kommunestruktur som Norge har, kan vi trygt gå ut fra at politisk lederskap er noe som varierer, ikke bare fra person til person, men også fra kommune til kommune og fra region til region. Det er for eksempel lett å forestille seg at kommunestørrelse er noe som påvirker hvordan politisk lederskap kommer til uttrykk. I tillegg kan vi tenke oss at eksempelvis lokale saker og lokale tradisjoner og politiske kulturer gjør at ellers ganske like kommuner kan være svært forskjellige når det kommer til politisk lederskap. En del av disse lokale variasjonene innenfor Norges grenser vil komme til uttrykk i de påfølgende kapitlene. Men først og fremst er dette en bok som omhandler lokalpolitikere generelt, og som forsøker å tegne et bilde av det norske lokalpolitiske lederskapet i lys av de teoretiske betraktningene ovenfor.

Som utgangspunkt for den videre presentasjonen og diskusjonene i boken har vi stilt opp fire sentrale paradokser. Ordet «paradoks» kommer fra latin og gresk, og de to leddene i ordet kan oversettes med «mot» og «fornuft». Et paradoks er dermed noe som strider mot fornuften, men som ved nærmere ettertanke likevel viser seg å inneholde en viss sannhet. Et eksempel på et klassisk paradoks kan være uttrykket «evig eies kun det tapte» i Henrik Ibsens teaterstykke Brand. I denne boken bruker vi ordet paradoks i en mer hverdagslig betydning. Et paradoks er noe uventet eller merkelig, for eksempel at noen på den ene siden har en 
målsetting, samtidig som de på den andre siden handler på måter som virker motsatt vei. Paradokser ber om nærmere forklaring, og det er nettopp slike forklaringer vi skal gi i de enkelte kapitlene som omhandler de fire paradoksene.

Konfliktparadokset handler om manglende overenstemmelse mellom den formelle modellen som ligger til grunn for det politiske arbeidet i et kommunestyre, og den måten politiske prosesser og politisk lederskap faktisk blir utøvet på (Martinussen, 2002). Dette er omtalt av andre som «parlamentarisme light» eller «kvasiparlamentarisme». Bakgrunnen er at omtrent alle norske kommuner styres etter formannskapsmodellen, som ble innført allerede med formannskapslovene i 1837. Formannskapsmodellen er en kollegial politisk modell som legger til grunn at alle de valgte representantene bidrar i utformingen av politikk, og at representantene når frem til felles beslutninger gjennom diskusjon og forhandlinger. I sin spede start fungerte formannskapsmodellen som en formell ramme for at byens og bygdas «fremste menn» skulle kunne drøfte seg frem til løsninger til beste for lokalsamfunnet. Mens formannskapsmodellen bygger på en idé om konsensus som bærende verdi, er den i økende grad blitt fylt med konflikt. Dette har først skjedd gjennom en gradvis institusjonalisering av de politiske partiene på lokalt nivå (Kjellberg \& Hansen, 1979), og i senere år gjennom at mange kommunestyrer har fått en blokkdeling tilsvarende den vi finner på Stortinget, med en klart definert posisjon og opposisjon. Det kan være mange og sammensatte forklaringer på hvorfor en i utgangspunktet kollegial og konsensusorientert politisk styringsmodell over tid har fått dette innholdet. I denne boken har vi ikke ambisjoner om å gi en fullgod forklaring på utviklingen. I stedet er vi opptatt av hvilke konsekvenser dreiningen mot konflikt har for politisk lederskap. Hva betyr konfliktorienteringen med tanke på den interne fordelingen av politisk lederskap, og hvilke konsekvenser har dette for rekruttering til politikken, innholdet i den politiske debatten og lokalpolitikernes evne til å fatte beslutninger?

Administrasjonsparadokset handler om en manglende overenstemmelse mellom teorien om politisk lederskap referert over, og hvilke prosesser politikerne faktisk er involvert i. Paradokset er nært knyttet til regler i kommuneloven og til den såkalte timeglassmodellen, som mange 
kommuner legger til grunn for organiseringen av forholdet mellom politikk og administrasjon. Bakgrunnen for paradokset er understrekningen av politikernes rolle som overordnede strategiske ledere med et vidt ansvar for egne kommuner og lokalsamfunn. Dette var et viktig prinsipp da kommuneloven gjennomgikk en omfattende revisjon rundt 1990. I lys av den forståelsen av politisk lederskap som ligger til grunn for denne boken, fremstår det som paradoksalt at kommunestyrerepresentantene i liten grad er direkte involvert i de fasene av politikkutviklingen der problemer identifiseres, forstås, utredes og blir utgangspunkt for alternative løsninger. Dette er i stor grad blitt overlatt til administrasjonen, som over tid har utviklet utredningskapasitet og tilført fagkunnskap. Men det har samtidig medført at politikernes oppgave i stor grad handler om å ta stilling til forslag fra administrasjonen. For folkevalgte kan dette innebære at deres første møte med et gitt problem blir et konkret løsningsforslag fra administrasjonen. Dette er i så fall en begrenset form for politisk lederskap. De fleste politiske systemer, inkludert det norske, forutsetter at politikk og administrasjon kan skilles fra hverandre. Spørsmålet er om det kan skje på andre måter enn ved å redusere kommunestyrets rolle til i så stor grad å dreie seg om å fatte beslutninger på grunnlag av administrative innstillinger.

Åpenhetsparadokset handler om en motsetning mellom regler om åpenhet og demokrati på den ene siden, og om de faktiske konsekvensene av disse reglene på den andre siden. Bakgrunnen er at vi i Norge har et formelt krav om møteoffentlighet i alle kommunale politiske organer. Andre sammenliknbare land har krav om generell møteoffentlighet i kun det øverste organet (tilsvarende kommunestyret), mens dette kravet for Norges vedkommende også gjelder for formannskapet, kommunestyrekomiteer og kommunale utvalg. De norske prinsippene for møteoffentlighet ble nedfelt i kommuneloven av 1992, der hensikten var å sikre allmenhetens innsyn og på den måten styrke åpenhet og demokrati. Selv om det er unntak for saker som berører taushetsbelagte opplysninger eller bedriftsinterne forhold, innebærer dette at norske kommunepolitikere i praksis ikke har arenaer der de kan diskutere politiske saker uten medias tilstedeværelse. Slike regler for åpenhet kan lett bli paradoksale dersom de i realiteten leder til at de reelle politiske diskusjonene flyttes ut av det 
formelle systemet og inn i fora som ikke reguleres gjennom kommuneloven. Vi skal se at reglene om generell møteoffentlighet kan ha ført til at de reelle politiske diskusjonene heller tas i partienes gruppemøter og andre uformelle og lukkede arenaer på utsiden av det formelle styringssystemet. I så fall har dette konsekvenser for politisk lederskap.

Til sist diskuterer vi demokratiparadokset, som handler om konflikten mellom det suverene politiske lederskap versus det suverene folk, som vi introduserte innledningsvis. Demokrati bygger på en forestilling om det suverene folk, der borgerne selv skal bestemme over sine liv. Forestillingen om det suverene folk er egalitær; alle skal ha samme mulighet for å delta, bli hørt og gjøre sin innflytelse gjeldende. Prinsippet om «én person - én stemme» står sentralt i demokratitenkningen. Den samme logikken finnes i ideen om deliberativt demokrati. Her er det ikke folks autoritet eller ekspertise som er avgjørende i en politisk diskusjon, men kvaliteten i argumentet. Alle kan fremme sine argumenter i en politisk debatt, og det beste argumentet vinner. Demokratiparadokset oppstår fordi den grunnleggende likhetstanken i den demokratiske forestillingen om det suverene folk strider mot selve grunntanken i det suverene politiske lederskap. Kjernen i forestillingen om politisk lederskap er at vi har bruk for noen som setter dagsorden gjennom å definere problemer og utfordringer som krever handling. Dessuten forventer vi at politiske ledere peker ut en retning, bidrar med løsningsforslag og sikrer gjennomføringen. Det er typisk personer som «stikker seg ut», og som skiller seg ut fra mengden i kraft av ressurser, karisma og veltalenhet, som blir rekruttert inn i politikken. Slik sett er politisk lederskap elitepreget og står i motsetning til egalitære prinsipper og verdier som kommer til uttrykk i forestillingen om det suverene folk. Problemet er at vi har bruk for både et suverent politisk lederskap, som kan løse samtidens presserende samfunnsproblemer, og et suverent folk, som er garantien for vårt demokrati. Det er vanskelig å sikre borgerne like muligheter for demokratisk innflytelse i et system hvor vi samtidig ønsker et klart og tydelig og på mange måter elitepreget politisk lederskap. Rent teoretisk kan det dermed hevdes at vi står overfor et paradoks i form av en konstant og uløselig spenning mellom demokrati og politisk lederskap (Kane \& Patapan, 2012). Hvordan dette paradokset løses i praksis, er et sentralt tema i kapitlet om demokratiparadokset. 


\section{Bokens innhold}

Denne boken handler først og fremst om politisk lederskap i norske kommuner, men i flere av kapitlene sammenlikner vi Norge og Danmark. Av alle land vi kan sammenlikne oss med, er våre skandinaviske naboer oss selv likest. Det skyldes blant annet en felles overordnet samfunnsmodell, med en ambisiøs velferdsstat som lar kommuner stå for store deler av velferdsstatens tjenesteproduksjon. Av dette følger ikke bare at oppbygningen av de politiske systemene i skandinaviske land er svært lik, men også at utfordringene er omtrent de samme. I lys av dette er det ikke uventet at det skjer en omfattende utveksling av reformideer og innovasjoner over de skandinaviske landegrensene. Vi har systematisert likheter og forskjeller mellom Norge og Danmark i teksten som følger dette kapittelet, og vi gir også en beskrivelse av datagrunnlaget for boken i et eget vedlegg.

Å sammenlikne oss med Danmark er spesielt relevant når det gjelder politisk lederskap. Det finnes åpenbare forskjeller mellom Norge og Danmark. Danske kommuner er for eksempel gjennomgående mye større enn norske kommuner, avstandene er kortere i Danmark enn i Norge, og topografien i Danmark er enklere enn i Norge. Samtidig er det mange likheter, for eksempel i administrativ og politisk organisering og i de oppgavene som kommunene har ansvar for. Det mest interessante i vår sammenheng er imidlertid noen viktige forskjeller som knytter direkte an mot de fire paradoksene, og som tillater oss å analysere paradoksene på en systematisk måte. Når det gjelder «konfliktparadokset», er Danmark interessant fordi forskere har argumentert for at den deliberative tradisjonen står sterkere i Danmark enn i Norge (Aarts, Thomassen \& van Ham, 2014). Når det gjelder «administrasjonsparadokset», er Danmark interessant ettersom det ikke finnes noe dansk motstykke til den norske kommunedirektøren. I stedet er danske ordførere (borgmestere) formelle ledere for administrasjon. I Danmark er altså forholdet mellom politikk og administrasjon organisert på en helt annen måte enn i Norge. Når det gjelder «åpenhetsparadokset», er Danmark relevant for sammenlikning i og med at danske kommuner kun har krav om generell møteoffentlighet $\mathrm{i}$ kommunestyret, mens utvalgsmøter alltid er lukket, noe som står i skarp motsetning til norske regler. Og når det gjelder «demokratiparadokset», 
er den allmenne oppmerksomheten rundt innbygger- eller borgerdeltakelse ansett som større i Danmark enn i Norge.

Med overordnet utgangspunkt i de fire paradoksene beskrevet over, vil vi på ulike måter drøfte hva disse forskjellene mellom Norge og Danmark betyr i praksis, og på hvilken måte de nasjonale rammene i Norge og Danmark åpner for lokale tilpasninger og institusjonelle endringer som kan styrke politisk lederskap, bredt forstått. I de påfølgende kapitlene diskuterer vi paradoksene hver for seg. I intervjuer med erfarne ordførere og kommunedirektører fra ulike norske kommuner, som følger etter den faglige teksten i hvert av kapitlene, presenteres også innspill til diskusjonen fra noen som kjenner praksis svært godt. Et overordnet budskap i denne boken er at nasjonale tradisjoner og institusjonelle rammebetingelser påvirker måten politisk lederskap utøves på i norske kommuner. Samtidig viser vi at det er mange muligheter for lokale tilpasninger, og at kommuner som ønsker å styrke det politiske lederskapet, har betydelig handlingsrom. Derfor er politisk lederskap noe som bør stå på dagsordenen når nasjonale rammebetingelser for norske kommuner utformes. Det bør også være et tema for diskusjon i norske kommunestyrer. Bokens siste kapittel summerer opp de enkelte kapitlene og drøfter hvordan nasjonale rammebetingelser eventuelt kan forbedres. I tillegg drøfter kapitlet hvordan politisk lederskap kan utvikles lokalt innenfor de eksisterende nasjonale rammebetingelsene.

\section{Referanser}

Baldersheim, H. (2011). Folkevald i kommunen: representantrolla under press? I H. Baldersheim \& E. Smith (Red.), Lokalt demokrati uten kommunalt selvstyre? Oslo: Abstrakt forlag.

Baldersheim, H. \& Rose L. E. (2011). Hvordan fungerer lokaldemokratiet? Kartlegging av innbyggernes og folkevalgtes erfaringer og oppfatninger. En sammenfattende rapport basert på 82 kommuner. Oslo: Institutt for statsvitenskap, Universitetet i Oslo.

Birkland, T. A. (2016). An introduction to the policy process. Theories, concepts, and models of public policy making (4. utg.). New York: Routledge.

Blondel, J. (1987). Political leadership. London: SAGE.

Burns, J. M. (1998). Transactional and transforming leadership. I G. R. Hickman (Red.), Leading organizations. London: SAGE. 
Dalton, R. J. \& Welzel, C. (Red.). (2014). The civic culture transformed: From allegiant to assertive citizens. Cambridge, England: Cambridge University Press.

Dye, T. R. (2017). Understanding public policy (15. utg.). Englewood Cliffs, NJ: Prentice-Hall.

Elgie, R. (2014). The institutional approach to political leadership. I J. Kane \& H. Patapan (Red.), Good democratic leadership. Oxford, England: Oxford University Press.

Esaiasson, P. (2010). Is citizen political involvement always a plus? I E. Amnå (Red.), New forms of citizen participation. Normative implications. Baden-Baden: Nomos.

Fung, A. \& Wright, E. O. (2003). Deepening democracy: Institutional innovations in empowered participatory governance. London: Verso.

Haga, G., Leirset, E. \& Lillestøl, Ø. (2014). Kommunestyre og lokaldemokrati. En empirisk undersøkelse av makt tillagt kommunestyret. Rapport nr 94. Steinkjer: Høgskolen i Nord-Trøndelag.

Hartley, J. \& Benington, J. (2011). Political leadership. I A. Bryman, D. Collinson, K. Grint, B. Jacksom \& May Uhl-Bien (Red.), The SAGE handbook of leadership. Los Angeles: SAGE.

Helms, L. (2014). Institutional analysis. I R.A.W. Rhodes \& P. 't Hart (Red.), The Oxford handbook of political leadership (s. 195-209). Oxford, England: Oxford University Press.

Helms, L. (Red.). (2016). Comparative political leadership. London: Palgrave MacMillan.

Hendriks, F. \& Karsten, N. (2014). Theory of democratic leadership. I R.A.W. Rhodes \& P. 't Hart (Red.), The Oxford handbook of political leadership. Oxford, England: Oxford University Press.

Jenssen, S. (2010). Lokaldemokrati på tomgang? Norsk statsvitenskapelig tidsskrift, 26(3), 204-234.

Kane, J. \& Patapan, H. (2012). The democratic leader. How democracy defines, empowers, and limits its leaders. Oxford, England: Oxford University Press.

Keohane A. O. (2014). Western political thought. I R.A.W. Rhodes \& P. 't Hart (Red.), The Oxford handbook of political leadership (s. 25-40). Oxford, England: Oxford University Press.

Kjellberg, F. \& Hansen, T. (1979). Det kommunale hamskifte. Oslo: Gyldendal.

Larsen, H. O. \& Offerdal, A. (1990). Demokrati uten deltakere? Arbeidsvilkår og lederroller i kommunepolitikken. Oslo: Kommuneforlaget.

Lidström, A., Baldersheim, H., Copus, C., Hlynsdottir, E. M., Kettunen P. \& Klimovsky, D. (2016). Reforming local councils and the role of councillors: A comparative analysis of fifteen European countries. I S. Kuhlmann \& G. Bouckaert (Red.), Local public sector reforms in times of crisis. National trajectories and international comparisons. London: Palgrave Macmillan. 
Martinussen, P. E. (2002). In search of the government in local government: Coalition agreements and office payoffs in Norway. Scandinavian Political Studies, 25(2), 139-171.

Masciulli, J., Molchanov, M.A. \& Knight, W. A. (2009). The Ashgate research companion to political leadership. London: Ashgate.

Mudde, C. (2016). On extremism and democracy in Europe. London: Routledge.

NOU 1990:13. (1990). Forslag til ny lov om kommuner og fylkeskommuner. Hentet fra https://www.regjeringen.no

NOU 2016: 4. (2016). Ny kommunelov. Hentet fra https://www.regjeringen.no

Nye, J. (2008). The powers to lead. Oxford, England: Oxford University Press.

Osborne, D. \& Gaebler, E. (1991). Reinventing government. Reading, MA: Addison-Wesley.

Sørensen, E. (2017). Political innovations: innovations in political institutions, processes and outputs. Public Management Review, 19(1), 1-19.

Sørensen, E. (2019). Interactive political leadership. Oxford, England: Oxford University Press.

Sørensen, E. \& Torfing, J. (2016). Political leadership in the age of interactive governance: reflections on the political aspects of meta-governance.

I J. Edelenbos \& I. van Meerkerk (Red.), Critical reflections on interactive governance. Cheltenham, England, Edward Elgar.

Torfing, J. \& Ansell, C. (2017). Strengthening political leadership and policy innovation through the expansion of collaborative forms of governance. Public Management Review, 19(1), 37-54.

Tucker, R. C. (1995). Politics as leadership. Revised Edition. Columbia, MO: University of Missouri Press.

Uhl-Bien, M., Riggio, R. E., Lowe, K. B. \& Carsten, M. K. (2014). Followership theory: A review and research agenda. The Leadership Quarterly, 25(1), 83-104.

Willumsen, T. (2014). Lokalt politisk lederskap. I H. Baldersheim \& L.E. Rose (Red.), Det kommunale laboratorium. Teoretiske perspektiver på lokal politikk og organisering. Oslo: Fagbokforlaget.

Winsvold, M. (2019). KS' Lokaldemokratiundersøkelse. Notat 7. Februar 2019. Oslo: UiO/ISF.

Winsvold, M. (Red.). (2013). Veier til god lokaldemokratisk styring. NIBR-rapport 2013: 24. Oslo: NIBR.

Winsvold, M. Sandkjær Hanssen, G., Houlberg, K., Klausen, J. E., Saglie, J., Bock Segaard, S. \& Vabo, S. I. (2015). Lokalpolitisk lederskap og medvirkning ved kommunesammenslåinger. Rapport 2015: 09. Oslo: Institutt for samfunnsforskning.

Aars, J. \& Offerdal, A. (2012). Norske kommunestyrerepresentantar i europeisk lys. Rapport frå ei undersøking av representantar i 14 ulike land. Bergen: Uni Research AS. 
Aarsæther, N. \& Vabo, S. I. (2002). Fristilt og velstyrt? Fokus på kommune-Norge. Oslo: Samlaget.

Aarsæther, N., Jenssen, S. \& Røiseland, A. (Red.). (2008). Practicing local governance: Northern perspectives. New York: Nova Science Publishers.

Aarsæther, N. \& Mikalsen, K. H. (Red.). (2015). Lokalpolitisk lederskap i Norden. Oslo: Gyldendal Akademisk.

Aarts, K., Thomassen, J. \& van Ham, C. (2014). Globalization, representation, and attitudes towards democracy. I J. Thomassen (Red.), Elections and democracy: representation and accountability. Oxford, England: Oxford University Press. 


\title{
Som to dråper vann? Norske og danske kommuner
}

\author{
Av: Signy Irene Vabo og Asbjørn Røiseland
}

I mange sammenhenger regner vi Norge og Danmark som svært like. Når forskere sammenlikner de to landene, gjør de gjerne et poeng av at begge er relativt små enhetsstater med omtrent samme nasjonale parlamentariske system. Begge land har et partisystem med både nasjonale og lokale partiorganisasjoner, og begge har et kommunesystem med både regioner og kommuner. I begge landene har kommunene dessuten ansvar for et omfattende tjenesteapparat, og i nasjonale velferdsstater som både Norge og Danmark er kommunene avgjørende.

Men selv om likhetene er store, så er det likevel viktige forskjeller mellom Norge og Danmark. Én slik forskjell er størrelse. Etter den danske kommunereformen i 2007, som reduserte antall kommuner til 98, ble gjennomsnittlig kommunestørrelse i Danmark 55 ooo innbyggere. Det tilsvarende tallet i Norge er betydelig lavere, og gjennomsnittet var 15000 innbyggere etter kommunereformen - altså ved inngangen til 2020. I forbindelse med den danske kommunereformen fikk danske kommuner dessuten betydelig mer myndighet, for eksempel på arbeidsmarkedsområdet. Dette gjør de danske kommunene enda mer sentrale i velferdspolitikken enn de norske. Og i tillegg ble Danmark hardere rammet av finanskrisen i 2008 enn Norge, noe som har medført betydelig mer omfattende omprioriteringer i danske kommuner sammenliknet med norske kommuner.

I denne boken er vi spesielt opptatt av hvordan forskjeller i rammebetingelser for kommuner i de to landene påvirker politisk lederskap. Slike rammebetingelser kan handle om kommunelovgivning, andre typer formelle regler samt tradisjoner og praksiser som har vokst frem over tid. Gitt dette utgangspunktet er det gunstig at landene er relativt like på overordnet nivå. Samtidig er det noen viktige forskjeller i norske og danske kommuners rammebetingelser som gjør dem spesielt interessante 
å sammenlikne i et forskningsprosjekt. Nedenfor lister vi opp noen slike forskjeller som vi oppfatter som relevante for utøvelsen av lokalpolitisk lederskap, og som vi vil komme inn på i de ulike kapitlene i boken.

Antall representanter: Mens norske kommunestyrer og tilhørende utvalg og komiteer besittes av relativt mange representanter, så er det betydelig færre folkevalgte i danske kommuner. I Norge skal et kommunestyre bestå av ikke færre enn elleve representanter (selv om kommunen har under 5000 innbyggere). Har kommunen mellom 5000 og 10 ooo innbyggere, skal antallet være minst 19. Det er ikke angitt noen øvre grense for antallet representanter i norske kommunestyrer - dette avgjør kommunestyret selv. I Danmark sier reglene at antallet kommunestyrerepresentanter i kommuner med færre enn 20000 innbyggere, ikke skal være færre enn ni, men heller ikke flere enn 31. I kommuner med flere enn 20 ooo innbyggere skal antallet være minst 19 og maksimalt 31, mens det høyeste antallet representanter i København er 55. Til sammenlikning sier de norske reglene at antallet representanter i norske kommuner med flere enn 100 ooo innbyggere skal være minst 43. Denne forskjellen i reguleringene fører til at det gjennomgående er større kommunestyrer i norske kommuner enn i danske. Eksempelvis har Oslo bystyre 59 medlemmer, Trondheim kommunestyre har 67, og Kristiansand kommunestyre har 71, mens i de minste kommunene, for eksempel Røst med sine litt færre enn 500 innbyggere og Utsira med omkring 200 innbyggere, velges det altså inn elleve representanter i kommunestyret.

Denne forskjellen i politisk-administrativt system medfører at innbyggerne vil være representert $\mathrm{i}$ kommunestyret i betydelig større grad i Norge enn hva tilfellet er i Danmark. Dette forsterkes av den store forskjellen i kommunestørrelse. Mens vi har mange små kommuner i Norge (omkring 170 kommuner med færre enn 5000 innbyggere etter kommunereformen), så finner vi kun en håndfull kommuner med færre enn 20 ooo innbyggere i Danmark. Dette representerer en viktig forskjell i relasjonen mellom innbyggerne og de folkevalgte i de to landene. 
Ordførerens rolle: Ordførerne utpekes av kommunestyret både i norske og danske kommuner - og velges altså ikke direkte av innbyggerne. Men mens en norsk ordfører formelt sett er møteleder og rettslig representant for kommunen, er en dansk ordfører - som jo kalles borgmestere - i tillegg øverste leder for administrasjonen. Med andre ord er deler av den funksjonen som norske kommunedirektører (rådmenn) ivaretar, i Danmark tillagt rollen som borgermester. Dette innebærer blant annet at skillet mellom den administrative og politiske delen av kommuneorganisasjonen er tydeligere og sterkere i Norge enn i Danmark.

Organiseringen av utvalg og komiteer: I Norge står kommunestyret fritt til å opprette faste eller midlertidige utvalg eller komiteer - ut over formannskapet, som er lovpålagt. Det er ikke noe krav om at de organene som etableres, kun skal bemannes av representanter fra kommunestyret. I Danmark står kommunestyret på samme måte fritt til å etablere faste eller midlertidige utvalg ut over økonomiutvalget, som er pålagt ved lov. Men ved etablering av faste utvalg er det et kravi Danmark at medlemmene skal rekrutteres fra kommunestyret. Grunnen til dette er at utvalgene kan ha delegert myndighet, og i praksis har de ofte også det for den delen av forvaltningen som utvalget dekker. Selv om norske utvalg og komiteer kan delegeres ansvar, så vil de ikke kunne gis ansvar for forvaltningen på samme måte som i danske kommuner. Dette følger av norsk lovgivning og av det samlede ansvaret som er tillagt rollen som kommunedirektør. Det sterke og formelle skillet mellom politikk og administrasjon i norske kommuner gjenspeiler seg dermed også i utvalgenes og komiteenes arbeid.

Møteoffentlighet: Alle politiske møter i norske kommuner er som hovedregel åpne for publikum og media, og dette følger av den norske kommuneloven. I Danmark gjelder åpenhetskravet kun møtene i kommunestyrene, og danske utvalgs- og komitémøter er lovpålagt å være lukket. Denne forskjellen i møteoffentlighet kan ha betydning for politiske diskusjoner, politikkutforming og politisk lederskap. 


\title{
Konfliktparadokset \\ Samarbeid og konflikt i kommunepolitikken
}

\author{
Marte Winsvold \\ Universitetet i Oslo, Institutt for samfunnsforskning \\ Tina Øllgaard Bentzen \\ Roskilde universitet
}

\begin{abstract}
This chapter focuses on a paradox related to cooperation and conflict in local politics. Most Norwegian local governments are organized according to a model where political parties are proportionally represented in all political committees. While this model encourages consensus building, it has increasingly been filled with party-political conflicts. This chapter discusses the difficult balance between "cooperation" and "conflict" in local politics. We show how local councilors in Norway and Denmark perceive and relate to conflict, and we provide examples of destructive as well as constructive conflicts in local governments. In a brief and subsequent chapter, a Norwegian Mayor reflects on how to balance party-political conflicts and cooperation.
\end{abstract}

Keywords: party politics, consensus, conflict

\section{Introduksjon}

Formannskapsmodellen, som de fleste norske kommunestyrer er organisert etter, tilstreber at representanter fra partiene i kommunestyret skal være proporsjonalt representert i politiske komiteer og utvalg. På den måten legger modellen til rette for at de folkevalgte vil måtte samarbeide og diskutere seg frem til enighet på tvers av partiskillelinjer. Modellen bygger med andre ord på en idé om samarbeid og konsensus.

Sitering av denne artikkelen: Winsvold, M. \& Bentzen, T. Ø. (2020). Konfliktparadokset. Samarbeid og konflikt i kommunepolitikken. I A. Røiseland \& S. I. Vabo (Red.), Folkevalgt og politisk leder (Kap. 2, s. 34-61). Oslo: Cappelen Damm Akademisk. https://doi.org/10.23865/noasp.80.ch2

Lisens: CC BY-ND 4.0 
Hvorfor er da arbeidet i mange norske kommunestyrer likevel preget av konflikt? Målet med dette kapitlet er å forklare hvorfor det oppstår et tilsynelatende motsetningsforhold mellom samarbeid og konflikt i norske kommunestyrer, og hvordan spenningen mellom konflikt og samarbeid spiller seg ut i praksis. Hvordan klarer politikere fra ulike partier og med ulike syn på hva som er god politikk, å fatte felles beslutninger og se til at disse beslutningene blir gjennomført? Hvilke måter å organisere det politiske arbeidet på bidrar til å skape og tydeliggjøre konflikt, og hvilke bidrar til samarbeid? Og hva gjør graden av konflikt og samarbeid med politikernes evne til å utøve politisk lederskap - sette dagsorden, fatte beslutninger og mobilisere støtte?

For å svare på disse spørsmålene vil vi først diskutere hvordan de institusjonelle rammebetingelsene som kommunestyret er underlagt, kan bidra til henholdsvis konflikt og samarbeid. Dernest vil vi si noe om ulike typer konflikt og om konflikt og konsensus som ulike politiske handlingslogikker. Videre viser vi hvordan balansen mellom konflikt og konsensus utspiller seg, og hvilke konsekvenser denne balansen oppleves å ha i norske kommuner. Der det er relevant, bringer vi også inn eksempler fra danske kommuner.

Kapitlet bygger i hovedsak på KS sin demokratiundersøkelse som ble gjennomført i 75 norske kommuner i 2017 og 2018. Kapitlet trekker også på kvalitative intervjudata samlet inn i samme periode i åtte kommuner i Norge og Danmark.

\section{Konflikt og konsensus innbakt i institusjonene}

Konflikter eksisterer ikke løsrevet, men må alltid forstås relativt til konteksten de utspiller seg i. Derfor vil vi nå se nærmere på den særlige institusjonelle konteksten som vi retter søkelyset mot i denne boken: den norske formannskapsmodellen.

Omtrent alle norske kommuner styres etter formannskapsmodellen, som ble innført allerede i 1837 da norske kommuner for første gang ble etablert gjennom «formannskapslovene» (Næss, 1987; Hovland, 1987). I sin spede start fungerte modellen som en formell ramme for at byens 
og bygdas «fremste menn» skulle kunne drøfte seg frem til løsninger til beste for lokalsamfunnet. Formannskapsmodellen er en kollegial politisk modell som legger til rette for at alle de valgte representantene skal kunne bidra i utformingen av politikk, og for at de folkevalgte skal kunne komme frem til felles beslutninger gjennom diskusjon og forhandlinger i politiske organer. Formannskapet er sammensatt etter forholdstallprinsippet, og det saksforberedende arbeidet i både formannskap og komiteer og utvalg er organisert på tvers av partiskillelinjene. Dette fremmer en konsensusbasert beslutningsform; politikerne er forventet å skulle komme til enighet, og formannskapsmodellen gir lite organisatorisk støtte for synliggjøring av konflikt og begreper som «posisjon» og «opposisjon». Modellen kan dermed bidra til å dempe, men også skjule de konfliktene som eventuelt måtte finnes i kommunepolitikken (Skare, 2000; Aarsæther \& Bjørnå, 2016). Historisk kan fremveksten av en konsensusorientert organisasjonsform forklares med blant annet størrelsen på lokalsamfunnene. De fleste kommuner er og har vært svært små, og politikere fra forskjellige partier er gjerne naboer og bekjente (Sørhaug, 1984). Konfliktnivået må derfor være til å leve med, også utenfor kommunestyresalen. Normativt trekker formannskapsmodellen på ideen om at det gjennom diskusjon og samtale er mulig å nå frem til enighet, både om hvilke problemer som skal løses, og om hvordan problemene best kan løses (Habermas, 1984).

Formannskapsmodellen er imidlertid i økende grad blitt fylt med konflikt. Det skjedde først gjennom en gradvis institusjonalisering av de politiske partiene på lokalt nivå, og gjennom at mange kommunestyrer har fått en blokkdeling tilsvarende den vi finner på Stortinget, med en klart definert posisjon og opposisjon (Martinussen, 2004). Når politikerne rekrutteres inn i kommunestyret, er det dermed gjennom et system som er tuftet på ulike verdisyn og forskjellighet. Ved valg fokuserer partiene på sine prioriteringer og fremhever gjerne hva som skiller dem fra andre partier. På den måten blir oppmerksomheten rettet mot hvilke politiske løsninger det er uenighet om, og inn i kommunestyrearbeidet bringer politikerne med seg en forpliktelse overfor sine velgere til å jobbe for de løsningene som de har gått til valg på. Lokale folkevalgte lever dermed i en spenning mellom to tilsynelatende uforenelige idealer: De må 
markere forskjeller og konkurrere samtidig som det forventes at de kommer til enighet, og de må arbeide for å få igjennom sin egen dagorden og sine egne løsninger samtidig som de må samarbeide om å lage en felles politikk for kommunen. I utøvelsen av vervet som folkevalgt balanserer dermed politikerne mellom konflikt og samarbeid. På den ene siden skal kommunestyrerepresentantene slåss for de løsningene som deres eget parti har gått til valg på - som å innføre eller fjerne eiendomsskatt, å legge ned eller bevare en skole, å verne friområder eller å omregulere dem til næringsformål. På den andre siden må de folkevalgte jobbe sammen for å finne løsninger på de utfordringene kommunen står overfor - som å sikre inntektskilder som kan dekke kommunens utgifter, å utforme et godt skoletilbud for alle kommunens barn og sikre at både friluftsliv og næringsutvikling har gode vilkår. Lokale folkevalgte har dermed et dobbelt sett forventinger rettet mot seg. De skal på samme tid være orientert mot forskjeller og konflikt, og de skal være orientert mot felles løsninger og samarbeid.

I litteraturen skilles det mellom «konsensusdemokrati», som kjennetegnes av at valgte politikere forsøker å komme til enighet på tvers av partipolitiske skillelinjer, og «majoritetsdemokrati», som kjennetegnes av at det partiet eller den koalisjonen som har flertall, styrer. Majoritetsdemokratier er typisk mer konfliktorientert (Lijphart, 1984, 1999). Formannskapsmodellen passer godt inn i beskrivelsen av et konsensusdemokrati. Kommuner organisert etter denne modellen, styres gjerne av inkluderende, brede koalisjoner. De har et proporsjonalt valgsystem og faste strukturer for inklusjon av gruppeinteresser utenfor den formelle valgkanalen. Slike institusjonelle systemer er i stand til å produsere konsensus også i samfunn preget av interessemotsetninger, blant annet fordi de innebærer at bare en svært stor majoritet kan kontrollere politikken, og i praksis har denne majoriteten en tendens til å ta hensyn til minoritetens ønsker og behov. I et majoritetsdemokrati, derimot, styrer den majoriteten som får flertall, alene, uten nødvendigvis å ta hensyn til minoritetens ønsker og behov.

Uenighet eksisterer innenfor både konsensus- og majoritetsdemokratier. Det som skiller de to demokratitypene, er hvordan uenighet håndteres. Mens majoritetsmodellen omfavner uenighet og viser konflikter 
åpenlyst, legger konsensusmodellen vekt på å bygge bro mellom motstridende interesser gjennom kompromisser (Skoog, 2018). Både norske og danske kommunestyrer fungerer i stor grad som typiske konsensusdemokratier, jamfør Lijpharts typologi, og konsensusorienteringen underbygges av måten de politiske organene er organisert på. I Norge styres kommunene etter en formannskapsmodell, og i danske kommuner er det såkalt borgmesterstyre, som i all hovedsak likner formannskapsmodellen, men med det unntak at «borgmesteren» har mer formell makt fordi hun også fungerer som leder av administrasjonen. De overordnede institusjonelle rammebetingelsene gir likevel ingen åpenbar grunn til å forvente ulik grad av konflikt i norske og danske kommuner.

Selv om organiseringsmodellen for norske og danske kommuner gjør at de kan klassifiseres som konsensusdemokratier, så kan kommunene i praksis være mer eller mindre konsensusorientert og mer eller mindre konfliktorientert. For eksempel er det forskjell mellom kommuner når det gjelder hvor bred den styrende koalisjonen er. I noen kommuner velger det største partiet å inkludere mange andre partier i styringskoalisjonen, i andre kommuner velger de å benytte seg av muligheten til å styre alene eller med en liten koalisjon. Grad av konfliktorientering kan også avleses av måten ordfører utøver rollen sin på. I konsensusorienterte kommuner vil rollen typisk utøves på en fasiliterende måte (Svara, 2003, Berg \& Kjær, 2007), som innebærer at ordfører navigerer gjennom den politiske prosessen ved å inkludere andre aktuelle aktører. I konfliktorienterte majoritetskommuner, derimot, vil ordfører først og fremst lede og være talsperson for den koalisjonen av partier som har majoritet i kommunestyret, og hun vil ha som mål å sørge for at majoritetens politikk blir vedtatt og effektivt gjennomført, uten å skjele så mye til opposisjonens meninger og synspunkter.

\section{Hva er konflikt, og hva er konsensus?}

Enkelt kan man si at politisk konflikt oppstår når to eller flere motstridende ønsker, behov eller motiver er til stede samtidig, eller når det er uenighet om målsettinger (Skoog \& Karlsson, 2018). Politisk konflikt 
oppstår fordi de politiske partiene representerer innbyggere med motstridende syn på hvordan samfunnet skal organiseres, og hvordan felles ressurser skal forvaltes. Politikk er et redskap til å håndtere og fatte beslutninger $i$ et landskap preget av interessemotsetninger, og i politikken er ulike og motstridende syn representert gjennom politiske partier.

Begrepene «samarbeid» og «konsensus» brukes gjerne om hverandre i dagligtalen. Det er imidlertid en analytisk forskjell mellom dem. Konsensus refererer til en situasjon der de som skal fatte beslutninger, faktisk har samme mening om hva som er den beste beslutningen. Samarbeid refererer til atferd som muliggjør en beslutning, men uten å forutsette at beslutningstakerne er helt enige om den beste løsningen (Lantto, 2005; Skoog, 2018). I et godt samarbeidsklima vil det være mulig å få til et kompromiss til tross for at partene står langt fra hverandre med hensyn til hva de tenker er den beste beslutningen. I en situasjon med konsensus er et kompromiss ikke nødvendig fordi partene faktisk er enige.

Konflikt kan komme til uttrykk på forskjellige måter, og i dette kapitlet vil vi skille mellom politisk uenighet og konfliktklima (på engelsk kalt «political dissent» og «antagonistic behaviour») (Skoog \& Karlsson, 2015, 2018).

Politisk uenighet beskriver en situasjon der politiske partier har ulike og motstridende synspunkter på hvilke saker som er viktige, på hvordan et godt lokalsamfunn skal se ut, eller på hvordan man skal nå de målene som er satt. Politisk uenighet kan man ha på en skala fra konsensus, som betyr at alle er enige om saker, mål eller metoder, til dissens, som betyr at man er uenige og har gitt opp å komme til enighet. I situasjoner der det ikke er konsensus, må politiske aktører inngå kompromisser for å få til en løsning, eller flertallet kan bestemme.

Konfliktklima beskriver hvordan politikere opptrer overfor hverandre. Et klima preget av høy konfliktorientering betyr for eksempel at politikerne kritiserer hverandre åpent, at de legger vekt på forskjeller, og at de forsøker å hindre hverandre i å få innflytelse. Politisk klima kan plasseres på en skala fra harmoni, som innebærer at politikere snakker pent og respektfullt til hverandre, at alle blir inkludert i politiske diskusjoner, og at man forsøker å få til et samarbeid, til disharmoni, som innebærer at 
politikerne krangler, ikke er på talefot og ekskluderer hverandre fra arenaer der politikk utformes.

Filosofen Chantal Mouffe (2000) kaller et politisk klima preget av disharmoni for antagonistisk. I et antagonistisk klima ser politikerne på hverandre som fiender, og de prøver å hindre hverandre i å få innflytelse eller å komme til orde overhodet. Dette står i motsetning til et såkalt agonistisk klima der politikerne ser på de som har andre meninger, som «legitime motstandere» som har samme rett til å ytre seg og delta $\mathrm{i}$ beslutninger som de selv har. Mouffe mener at agonisme - forstått som respektfull, regulert konflikt - er mer i tråd med politikkens natur enn konsensus, som hun mener ofte vil være et uttrykk for at noen har klart å få igjennom sin mening, og at andres meninger undertrykkes. I et agonistisk politisk klima vil politikerne anerkjenne at vedvarende uenighet finnes, og de vil bruke energien sin på å klare å fatte gode beslutninger og opprettholde en god og respektfull stemning, men uten noen ambisjon om at den politiske uenigheten skal opphøre.

Selv om politisk uenighet og konfliktklima beskriver ulike fenomener, så henger de i praksis slik sammen at det ofte er lettere å få til et samarbeid når den politiske uenigheten er liten (Adams \& Merrill, 2009; Skoog \& Karlsson, 2018). Det finnes likevel mange eksempler på at politikere eller partier som er svært uenige om politiske saker, likevel klarer å samarbeide, og det finnes eksempler på at partier som egentlig er ganske enige, ikke klarer det.

Grunnen til at vi skiller mellom politisk uenighet og politisk konfliktklima, er at de to typene konflikt har ulike konsekvenser for politikernes mulighet til å utøve politisk lederskap i alle faser av politikksyklusen. Politisk uenighet er et kjerneelement i demokratisk politikk og ligger til grunn for måten folket velger representanter på, og for muligheten folk har til å holde representantene til ansvar ved valg. Dersom det skal være meningsfullt å stemme, må det finnes politiske forskjeller mellom partiene med hensyn til hvilke saker de mener er viktige, og hva de mener er gode løsninger, og disse forskjellene bør gjenspeile menings- og prioriteringsforskjeller som finnes i befolkningen. Politisk uenighet er med andre ord en definerende del av det politiske, demokratiske systemet. 
Annerledes er det med politisk konfliktklima. På en akse fra harmonisk samarbeid til konfliktpreget ikke-samarbeid (antagonisme) vil samarbeid i de fleste tilfeller være å foretrekke. Strategisk vil politiske partier kunne velge en disharmonisk ikke-samarbeidslinje, i hvert fall i perioder, men som overordnet handlingsprinsipp er politikken helt avhengig av at de politiske partiene klarer å komme til enighet om løsninger. En viss grad av antagonistisk, konfliktorientert atferd kan bidra til å klargjøre forskjellene mellom partier, men en høy grad av slik atferd vil innebære at partier aktivt forsøker å stoppe hverandre fra å utøve politisk innflytelse. I så fall fungerer ikke lenger demokratiet slik det skal, fordi ikke alle stemmer blir hørt og ikke alle interesser blir representert.

Politisk konflikt kan altså handle både om interessemotsetninger (det vi har kalt politisk uenighet) og om vilje til å samarbeide (det vi har kalt konfliktklima). Overordnet vil man i samarbeidsorienterte kommuner legge vekt på hva man har felles, være opptatt av å gi noe til alle (rettferdighet er at alle får) og være innstilt på å inngå kompromisser. I konfliktorienterte kommuner vil man legge vekt på hva man er uenig om, være opptatt av at de løsningene som samler flest bak seg, skal velges (rettferdighet er at flertallet bestemmer), og se kompromisser som unødvendig dersom man får flertall for egen løsning.

\section{Balansen mellom konflikt og samarbeid}

Både graden av politisk uenighet og konfliktklima varierer mellom kommuner, og selv om store politiske forskjeller kan ha en tendens til å gjøre konfliktklimaet hardere, så trenger det som nevnt ikke å være noen sammenheng mellom politisk uenighet og konfliktklima. I figuren nedenfor har vi illustrert hvordan kombinasjoner av politisk uenighet og konfliktklima kan se ut, og vi har gitt ulike navn til kommuner med forskjellige kombinasjoner. Vi bruker betegnelsene «konfliktklima» og «samarbeidsklima» om hverandre. Et dårlig samarbeidsklima er det samme som et hardt konfliktklima. 


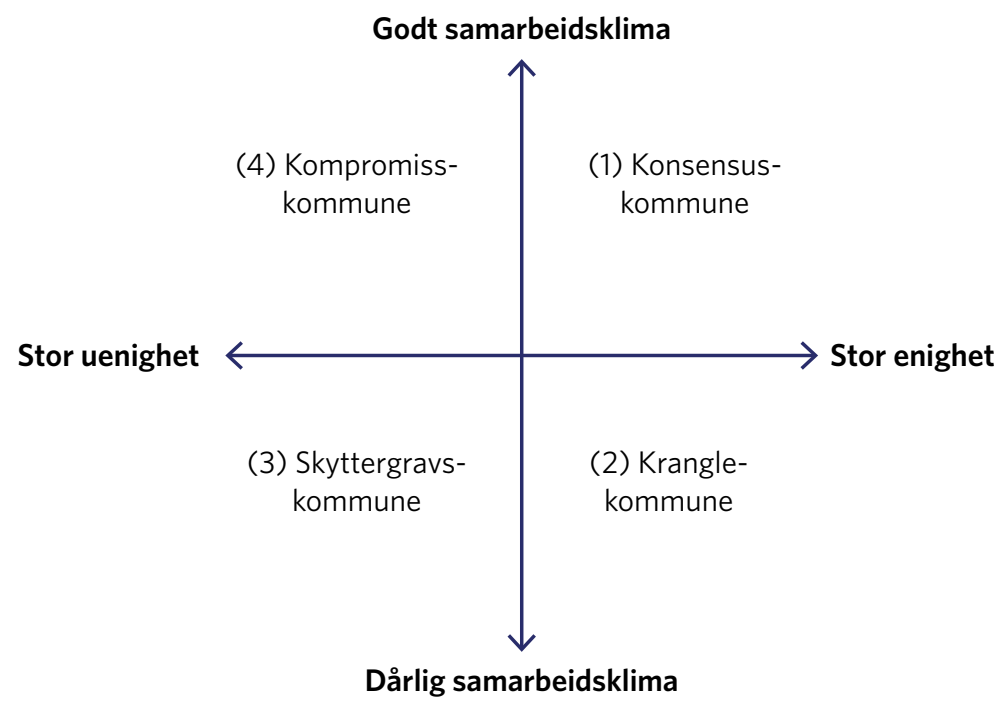

Figur 2.1 Politisk uenighet og konfliktklima/samarbeidsklima

Lettest har politikerne det $\mathrm{i}$ kommuner der det er stor politisk enighet og godt samarbeidsklima, i aksediagrammet kalt «konsensuskommuner». Her trenger ikke politikere å finne kompromisser, for det er faktisk enighet om de viktigste politiske spørsmålene. I slike kommuner har man gode forutsetninger for å få ting gjort fordi man slipper å bruke tid på å komme til enighet, men kan bruke all sin politiske energi på å utvikle gode løsninger på felles erkjente problemer. Konsensuskommuner vil typisk være kjennetegnet av at det er liten avstand mellom de politiske partiene, og det vil kunne være vanskelig for velgerne å finne ut hvem de skal stemme på. Opposisjon vil kunne være vanskelig når det store flertallet er enige, og i typiske konsensuskommuner oppgir ofte et lite mindretall at de føler seg ekskludert.

I noen kommuner kan det være slik at samarbeidsklimaet er dårlig til tross for at det egentlig er liten politisk uenighet og mulighetene for å finne felles løsninger egentlig burde være gode. Disse har vi kalt «kranglekommuner». Et dårlig samarbeidsklima kan skyldes personkonflikter eller at enkelte kranglete politikere lager dårlig stemning. Det kan også være maktpolitiske, strategiske årsaker til at partiene ikke vil samarbeide. 
Videre finnes det kommuner der den politiske uenigheten er stor, og der det er dårlig samarbeidsklima, her kalt «skyttergravskommuner». I slike kommuner vil det være vanskeligere å komme frem til kompromisser, og det vil være vanskelig å få gjort noe. Et dårlig samarbeidsklima kan sitte i veggene, men kan også utløses av en situasjon der politikerne opplever at mye står på spill, og der en løsning med nødvendighet vil føre til at noen taper og andre vinner. Skolenedleggelse er et vanlig eksempel på en sak som bidrar til et opphetet klima og skaper vonde konflikter, krangling og personangrep, og der sårene er vanskelige å lege.

Til sist finner vi kommuner som klarer å samarbeide til tross for stor uenighet - kalt «kompromisskommuner». Kompromissene som inngås, kan være både klassiske kompromisser, som innebærer at alle parter må gi noe, og løsninger som nærmer seg en form for konsensus, hvor politikere som i utgangspunktet er uenige, klarer å diskutere seg frem til løsninger som imøtekommer alle parters behov. Hva som skal til for å få til et godt samarbeidsklima i en kommune der de politiske forskjellene er store, finnes det ikke et godt svar på. Mange politikere trekker likevel frem ordførerens rolle som viktig. Der hvor politikerne oppfatter at ordføreren ønsker å få hele kommunestyret til å fungere som ett samlet organ, og at ordføreren er en ordfører for alle og ikke gir spesiell prioritet til eget parti eller koalisjon, oppgir politikerne ofte at de klarer å samarbeide til tross for store forskjeller.

De fire kommunetypene skissert over, gir et veldig forenklet bilde av hvordan virkeligheten ser ut. I mange kommuner er det forskjeller mellom politikkområder og fraksjoner i én og samme kommune. For eksempel kan det være konsensus på skolefeltet, men stor avstand og skyttergravskrig i næringspolitikken. Kommuner kan også bevege seg over tid - og kanskje over ganske kort tid - fra én type konfliktmodus til en annen. I intervjuer har politikere for eksempel fortalt om hvordan fastlåste situasjoner der den politiske uenigheten var stor og klimaet dårlig, har løst seg ved at den ene siden strakte ut en hånd som den andre siden så tok, eller ved at ordfører klarte å samle stridende parter og få dem til å samarbeide. Graden av politisk uenighet og graden av konflikt oppleves også naturlig nok ulikt for ulike politikere. 
I det videre skal vi se hvordan politikere i norske kommuner opplever graden av politisk uenighet og konfliktklima, og hvordan de to formene for konflikt håndteres i praksis. Deretter skal vi si noe om konsekvensene av politisk uenighet og dårlig samarbeidsklima, og til sist skal vi si noe om hva som er blitt gjort i ulike kommuner for å klare å fatte gode politiske beslutninger i situasjoner med henholdsvis stor politisk uenighet og dårlig samarbeidsklima.

\section{Opplevelsen av politisk uenighet og samarbeidsklima i norske kommuner}

Graden av politisk uenighet varierer mellom kommuner. En enkel måte å få et inntrykk av de politiske avstandene på er å se på hvilke partier som stiller til valg. I noen kommuner stiller først og fremst sentrumspartier til valg, i andre kommuner stiller også fløypartier, og disse kan ha ulik størrelse. På lokalt nivå er likevel ikke partitilhørighet nødvendigvis en god indikator på politisk avstand, fordi spesifikke lokale saker som ikke er skrevet inn i det nasjonale partikartet, er viktige. Politiske konflikter kan handle om hvorvidt eller hvordan man ønsker å utvikle et bestemt boområde, om man ønsker å slå seg sammen med nabokommunen eller ikke, eller om hvilken del av kommunen som skal ha status som sentrum.

Om det er godt eller dårlig samarbeidsklima, kan leses verken ut av partifordelingen eller av sakskartet. I kommuner der politikerne samarbeider godt, så finner de frem til løsninger som alle kan akseptere, posisjon og opposisjon snakker sammen, og politikere fra alle partier opplever seg inkludert i politikkutviklingen. Tonen er god, og politikerne behandler hverandre med respekt. I kommuner med dårlig samarbeidsklima er det motsatt.

Vi vet litt om utbredelsen av de to typene konflikt fordi KS i 2018 gjennomførte en spørreundersøkelse blant lokale folkevalgte der det blant annet ble stilt spørsmål om konflikt- og samarbeidsklima. Svarene som ble gitt, viste at det var stor variasjon mellom kommunene. I tabell 2.1 er gjennomsnittsverdiene for fire påstander om politisk uenighet og konfliktklima gjengitt. I de to første kolonnene har vi gjengitt 
gjennomsnittsskårene blant representantene i den kommunen med henholdsvis lavet og høyest skår. I den siste kolonnen er gjennomsnittsskåren for alle kommunestyrene i undersøkelsen gjengitt.

Tabell 2.1 Gjennomsnittsskår for påstander om politisk uenighet og samarbeidsklima. Skala 1 (passer svært dårlig) til 4 (passer svært godt). N = 1892-1905. Hentet fra KS' lokaldemokratiundersøkelse 2017/2018, gjennomført blant samtlige lokalpolitikere i 75 kommuner.

\begin{tabular}{|l|r|r|r|}
\hline & $\begin{array}{r}\text { Laveste } \\
\text { gjennomsnitt }\end{array}$ & $\begin{array}{r}\text { Høyeste } \\
\text { gjennomsnitt }\end{array}$ & $\begin{array}{r}\text { Gjennomsnitt } \\
\text { - alle }\end{array}$ \\
\hline $\begin{array}{l}\text { Det er klare partipolitiske skillelinjer i } \\
\text { kommunepolitikken }\end{array}$ & 2,1 & 3,5 & 3,0 \\
\hline $\begin{array}{l}\text { Her i kommunen er det gode relasjoner } \\
\text { mellom posisjon og opposisjon }\end{array}$ & 1,7 & 3,6 & 2,8 \\
\hline $\begin{array}{l}\text { I denne kommunen behandler } \\
\text { politikerne hverandre med respekt }\end{array}$ & 1,8 & 3,8 & 3,3 \\
\hline $\begin{array}{l}\text { Ordføreren er en ordfører for hele } \\
\text { kommunestyret }\end{array}$ & 2,2 & 3,8 & 3,2 \\
\hline
\end{tabular}

Den første påstanden - om skillelinjer i kommunepolitikken - sier noe om graden av politisk uenighet, og som vi ser, varierer gjennomsnittsskåren i kommunene fra 2,1, hvilket vil si at de fleste folkevalgte i kommunen mener at det er små partipolitiske forskjeller, til 3,5, som betyr at de folkevalgte opplever at det er store partipolitiske forskjeller. De tre neste påstandene sier noe om det politiske konfliktklimaet, og her er forskjellene enda større. I noen kommuner mener de fleste folkevalgte at det er svært dårlige relasjoner mellom posisjon og opposisjon, mens de i andre kommuner mener at relasjonene er gode. Tilsvarende forskjeller er det når det gjelder hvorvidt politikerne behandler hverandre med respekt, og om ordføreren er en ordfører for hele kommunestyret.

Det er altså stor variasjon langs begge konfliktaksene når det gjelder både politisk uenighet og konfliktklima. For å kunne illustrere hvordan kommunene plasserer seg langs de to aksene, har vi laget en indeks av de tre påstandene som måler konfliktklima. Hver kommune er representert med en verdi som er et uttrykk for gjennomsnittet av representantene i kommunen sitt syn på konfliktklimaet. En høy skåre på indeksen indikerer at klimaet oppfattes å være preget av samarbeid. I aksediagrammet 
nedenfor har vi plottet inn gjennomsnittsverdien for kommunene langs begge aksene, altså aksen for politisk uenighet (målt som partiforskjeller) og aksen for konfliktklima eller samarbeidsklima (målt som et gjennomsnitt av de tre påstandene som sier noe om klimaet).

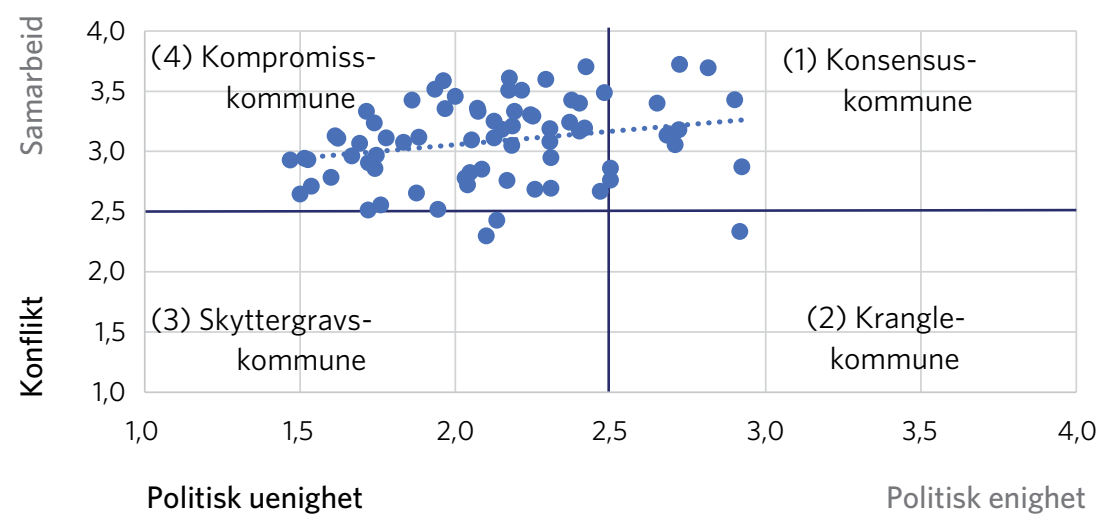

Figur 2.2 Politisk uenighet og konfliktklima. Hentet fra KS' lokaldemokratiundersøkelse 2017/2018, gjennomført blant samtlige lokalpolitikere i 75 kommuner.

Plottet angir gjennomsnittet av de folkevalgtes oppfatning i hver enkelt kommune. Den tydeligste trenden er at de folkevalgte i det store flertallet av kommuner opplever samarbeidsklimaet som mer godt enn dårlig (over den horisontale midtstreken). Videre ser vi at de fleste norske kommuner plasserer seg innenfor det vi kaller «kompromisskommuner» - med relativt stor politisk uenighet, men godt samarbeidsklima. En del, men likevel betydelig færre kommuner kan sies å være «konsensuskommuner», altså kommuner der det er både stor politisk enighet og godt samarbeidsklima. En liten håndfull kommuner rapporterer om dårlig samarbeidsklima og befinner seg i kategoriene for skyttergravs- eller kranglekommuner.

Figuren gir et gjennomsnittsbilde av hver av kommunene som er med i undersøkelsen, og den skjuler at det er variasjon mellom politikerne også innenfor en og samme kommune. Intervjuer vi har gjennomført, viser for eksempel at det i typiske konsensuskommuner ofte er enkeltpolitikere som opplever seg ekskludert og holdt utenfor det gode selskap, mens det i skyttergravskommuner er enkelte politikere som liker en god krangel, og som synes konfliktklimaet er akkurat som det bør være. Videre vil 
ofte opplevelsen av hvordan både politisk avstand og konfliktklimaet er, variere over tid. Blant annet er konfliktnivået nesten alltid høyere under valgkamp når det gjelder både politisk uenighet og samarbeidsklima.

Konfliktene fra valgkampen lever i større eller mindre grad videre i kommunestyret etter valget. De politiske standpunktene beveger seg vanligvis lite, så den egentlige politiske avstanden forblir ofte den samme. Hvilke løsninger politikerne er villige til å gå med på, vil imidlertid endre seg fordi man er avhengig av å kunne fatte vedtak i en forsamling der folk har forskjellige meninger om hvilken løsning som er riktig. Og det er her samarbeidsklimaet kommer inn. I noen kommuner får politikerne dette til på en god måte, i andre holder de fast ved sine opprinnelige løsninger, det blir vanskelig å komme til enighet, og vedtak blir fattet gjennom flertallsavgjørelser der noen opplever seg som vinnere og andre som tapere. Et kjennetegn ved et godt samarbeidsklima er, ifølge politikere vi har intervjuet, at det er en kultur for å lytte til, diskutere og vurdere forslag fra opposisjonen. I noen kommuner rapporterer politikerne fra både posisjon og opposisjon at det er vanlig å vurdere alle forslag som kommer opp, uansett hvilket parti de kommer fra, slik denne politikeren beskriver:

Her er det ikke sånn som på Stortinget, at hvis noe kommer fra opposisjonen, så stemmer vi «nei» uansett, og så etterpå fremmer samme forslag, bare med litt annen ordlyd. Vi lytter til hverandre og tar gjerne hverandres ideer. (Kommunestyremedlem i norsk kommune)

I andre kommuner er det vanntette skott mellom posisjon og opposisjon, og politikken er i praksis utformet enten i et flertallsparti alene eller i lukkede møter mellom koalisjonspartiene som sitter i posisjon. I slike kommuner vil ikke opposisjonen komme til orde.

Viljen til å inkludere kommer også til syne i måten makt og verv fordeles internt i kommunestyret på - og spesielt i hvorvidt opposisjonen inkluderes i politikkutviklingen. I noen kommuner vil man legge vekt på å etablere brede koalisjoner og gi små partier eller opposisjonspartier viktige roller som for eksempel utvalgsledere i sentrale utvalg. I andre kommuner vil majoriteten benytte anledningen til å få igjennom sin politikk, slik vi i større grad ser at det gjøres på Stortinget og i parlamentarisk styrte kommuner. 


\section{Hvilke konsekvenser har politisk uenighet og konfliktklima for politisk lederskap?}

Politikere vi har intervjuet, beskriver hvordan det er å være politiker i disse ulike typene kommunene. Klart mest fornøyd er de som er folkevalgt i kommuner der samarbeidsklimaet er godt. Det spiller ikke så stor rolle om det er små eller store politiske forskjeller. Mange synes det gir politisk driv, og at det er spennende at det finnes tydelige alternative meninger om hvilke saker som er viktige, og om hvilke løsninger som er gode. Et hardt konfliktklima, derimot, skaper mistrivsel og tapper politikerne for energi.

Statistikk fra KS’ lokaldemokratiundersøkelse bekrefter at politikere trives best i kommuner der samarbeidsklimaet er godt - og den politiske uenigheten kan gjerne være stor. Trivselen stiger jevnt når samarbeidsklimaet blir bedre, mens politisk uenighet ikke ser ut til å ha noen effekt på trivsel. Grafen nedenfor viser hvordan trivselen stiger med bedring $\mathrm{i}$ samarbeidsklima, mens endring i politisk enighet ikke ser ut til å ha noen effekt på trivsel.

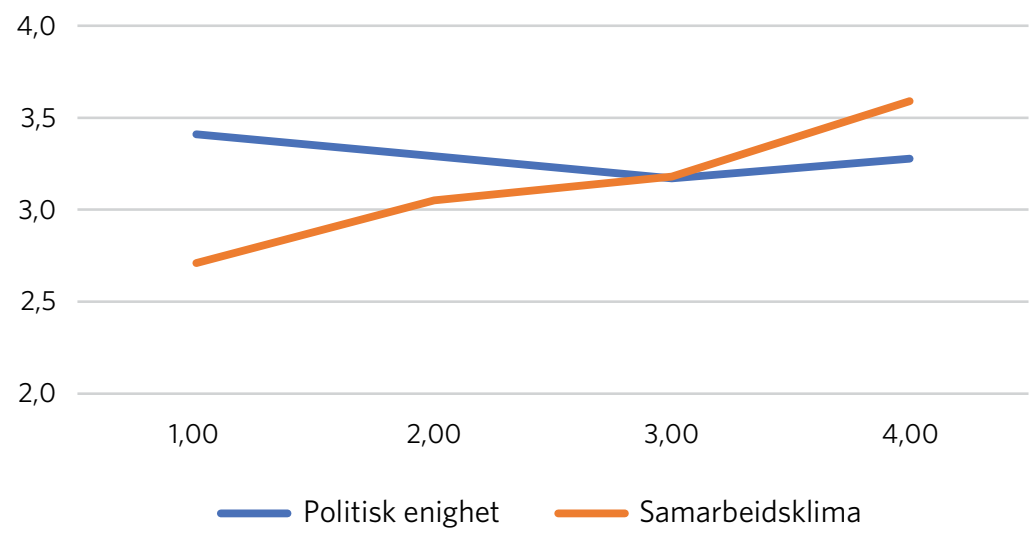

Figur 2.3 Trivsel blant politikere med ulik oppfatning av politisk enighet og samarbeidsklima. Enighet i påstanden «Alt i alt trives jeg godt med arbeidet som folkevalgt» på en skala fra 1 (helt uenig) til 4 (helt enig). $N=1892$. Tall hentet fra KS' lokaldemokratiundersøkelse 2017/2018. 
Den generelle tendensen er altså at politisk uenighet ikke har noe å si for hvorvidt politikerne trives eller ikke, men at samarbeidsklimaet betyr mye for trivselen.

I det videre undersøker vi hvilke konsekvenser politikerne opplever at henholdsvis politisk uenighet og samarbeidsklima har for de tre kjernefunksjonene i politisk lederskap - dagsordensetting, løsningsutpeking og mobilisering.

\section{Konflikt om dagsorden}

Politisk konflikt handler ofte om uenighet om hvilke saker som er viktige og skal stå på den politiske dagsordenen, og om hva man skal prioritere: Hva er viktigst? Er det eldreomsorg, næringsutvikling eller klima? Politiske partier har ulik politisk dagsorden, og innbyggere stemmer gjerne på partier som er opptatt av de samme sakene som dem selv. Politisk uenighet om dagsorden er viktig for å skille de ulike partiene fra hverandre, og politikerne selv ser på kamp om dagsorden som en politisk kjerneaktivitet som de liker.

Data fra KS’ lokaldemokratiundersøkelse viser at politikere i kommuner med tydelige politiske skillelinjer mellom partiene i større grad opplever at det er politikerne som setter dagsordenen, og at det er lettere å sette dagsorden her enn i kommuner der skillelinjene ikke er så tydelige. Det kan ha å gjøre med at de politiske prioriteringene blir tydeligere visà-vis administrasjonens prioriteringer i kommuner der dagsordenen tas opp til politisk diskusjon.

Et hardt konfliktklima ser ut til å ha motsatt effekt på opplevelsen av å kunne sette dagsorden. Politikerne synes det er lettere å sette dagsorden i kommuner med godt samarbeidsklima. Grad av politisk enighet betyr, slik figuren under viser, ikke noe for politikernes opplevelse av å kunne sette dagsorden. 


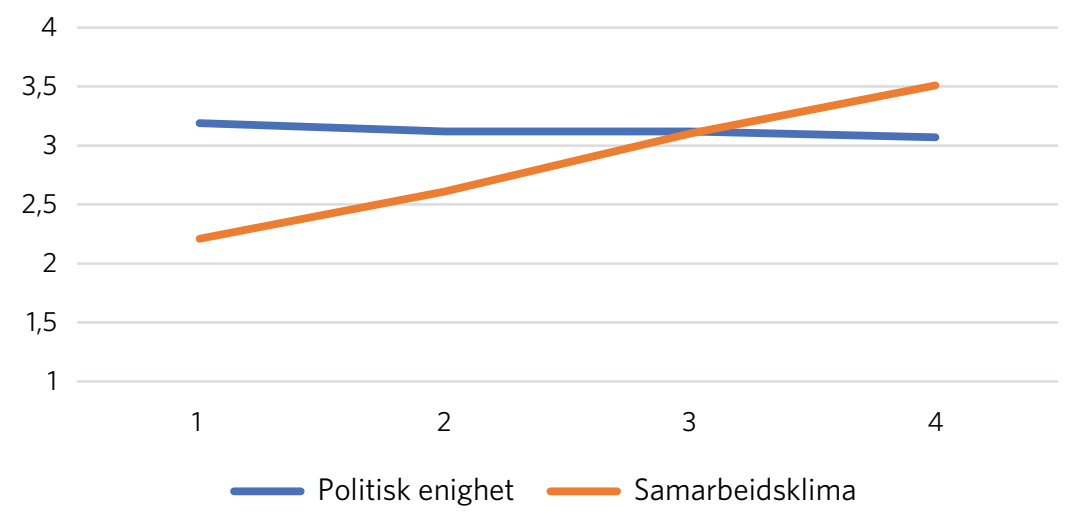

Figur 2.4 Opplevelse av mulighet for å sette dagsorden blant folkevalgte med ulik oppfatning av politisk enighet og samarbeidsklima. Enighet i påstanden «Her i kommunen er det lett for de folkevalgte å få satt en sak på dagsorden» på en skala fra 1 (helt uenig) til 4 (helt enig). $N=1892$. Tall hentet fra KS' lokaldemokratiundersøkelse 2017/2018.

Disse funnene underbygger det politikere ofte rapporterer når de blir intervjuet, altså at forskjeller og uenighet er en viktig del av politikken, men at de ønsker og trives med et politisk miljø der forskjeller og uenighet diskuteres og håndteres på en ordentlig måte, og der det ikke er fiendskap.

\section{Konflikt om løsninger}

Politisk konflikt om løsninger er også en definitorisk del av politikken og er institusjonalisert i partisystemet, særlig gjennom høyre-venstreaksen. Alle politiske partier ønsker gode velferdstjenester, men mens høyresiden ønsker at en større andel av velferdstjenestene skal produseres av private aktører, ønsker venstresiden at tjenestene skal produseres av det offentlige. Ut over dette grove og forenklede skillet er det lokalt stor politisk uenighet om hvilke løsninger som ivaretar et lokalsamfunn best, som hvorvidt bompenger er en god måte å finansiere veiutbygging, hvilken skolestruktur som gir det beste skoletilbudet, og så videre. Politikere er vant til å være uenige om løsninger, de er trent i å argumentere for egen løsning, og de fleste politikere gir uttrykk for at de opplever diskusjon av løsninger som en meningsfull del av politikergjerningen. Et dårlig 
samarbeidsklima, derimot, kan politikerne ofte oppleve som en hindring for å komme frem til gode løsninger.

I den ovenfor nevnte undersøkelsen fra KS er det også spurt om hvorvidt lokalpolitikerne føler at de får gjort nytte for seg. Dette er en indikasjon på om de opplever at de bidrar til å finne løsninger. Vurderingen av hvorvidt man får gjort nytte for seg som folkevalgt, positivt korrelert med politisk uenighet og negativt korrelert med konfliktklima.

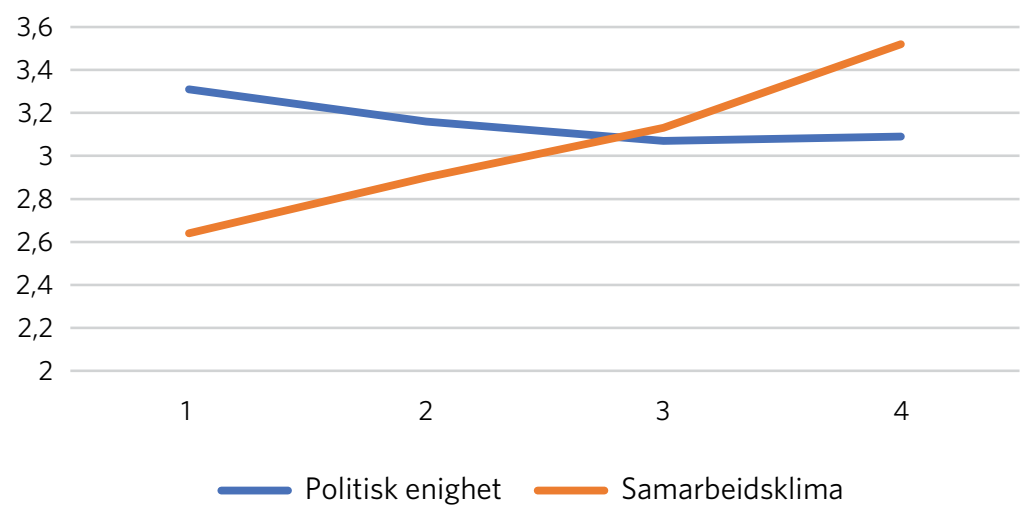

Figur 2.5 Opplevelse av å få gjort nytte for seg - blant folkevalgte med ulik oppfatning av politisk enighet og samarbeidsklima. Enighet i påstanden «Jeg føler at jeg får gjort nytte for meg som folkevalgt» på en skala fra 1 (helt uenig) til 4 (helt enig). $\mathrm{N}=1892$. Tall hentet fra KS' lokaldemokratiundersøkelse 2017/2018.

Som vi ser av figur 2.5, later det til at konflikt i betydningen uenighet og forskjeller gir politikerne mer makt og større handlingskapasitet, mens et dårlig samarbeidsklima kan føre til at politikerne roter bort gode løsninger, og til at administrasjonen må overta.

\section{Konflikt og mobilisering}

Både politisk uenighet og konfliktklima oppleves å påvirke politikernes evne til å mobilisere administrative ressurser for å gjennomføre ønskede løsninger. Der politikerne står samlet, oppleves det som lettere å få administrasjonen med på laget. Videre vil beslutninger som har bred støtte bak seg, vare lenger, og de blir ikke omgjort dersom 
partisammensetningen i kommunestyret endres, slik denne danske politikeren sier (vår oversettelse):

Dette årets budsjett ble vedtatt helt enstemmig i byrådet ... Sånn overveiende er vi enige og snakker oss frem til enighet, men det er også fordi det er kommet en forståelse av at det er bedre å få en meget bred løsning, enn det er å få en smal løsning. Fordi en smal løsning holder kun til de andre overtar makten. (Kommunestyremedlem i dansk kommune)

Vi vet ikke om politisk uenighet påvirker evnen til å mobilisere ressurser utenfor kommuneorganisasjonen, for eksempel i lokalsamfunnet, men det er grunn til å tro at åpenlys krangling skaper mistillit til politikere og ikke virker motiverende på folks ønske om å bidra.

\section{Hvordan klare å samarbeide til tross for stor politisk uenighet?}

Oppsummert ser det ut til at de fleste politikere trives godt med - og ønsker - politisk uenighet, men at et hardt konfliktklima hindrer dem i å utøve politisk lederskap. Som nevnt kan imidlertid politikere oppleve ett og samme politiske klima veldig ulikt. I de kommunene der mange rapporterer om stor politisk enighet, og om at man er «enige om de store linjene», er det gjerne også enkeltpolitikere som opplever enigheten som en begrensende forventning; det er vanskelig å ta til motmæle når alle andre snakker høyt om hvor enige de er. Tilsynelatende konsensus kan skjule at noen er uenige, men ikke opplever at det er rom for å heve stemmen. Bred politisk enighet kan altså være reell, eller den kan være et resultat av at én dominerende aktør eller konstellasjon som oppleves vanskelig å si imot, har fått sin mening igjennom. Ofte vil noen oppfatte politisk enighet som omforent og harmonisk, mens andre brenner inne med innvendinger de ikke har fått uttrykt, eller som de føler ikke er blitt lyttet ordentlig til. På samme måte vil noen kunne oppleve måten man snakker med og til hverandre på - konfliktklimaet - som negativt, mens andre opplever det som positivt. Det noen beskriver som frisk debatt, 
beskriver andre som krangling. Videre vil konfliktklima og uenighet ofte variere i løpet av en politisk prosess og også i løpet av en periode. For eksempel vil man kunne bevege seg fra uenighet til enighet etter diskusjon, eller et klima kan hardne til i løpet av en prosess.

Overordnet ser det likevel ut til at politikere trives best og opplever at de får gjort mest når det er tydelige forskjeller og uenighet, men når samarbeidsklimaet likevel er godt. Samarbeid til tross for meningsforskjeller ser ut til å være den foretrukne politiske handlingsmåten. Så hvordan får man det til? Hvordan unngår man at uenigheter utarter og fører til fiendskap og handlingslammelse? Og hvordan unngår man at noen sterke aktører får dominere politikkutviklingen, slik at eventuelle kritiske stemmer stilner eller resignerer?

Ordførerrollen ser ut til å være et sted å begynne. I de mange intervjuene vi har gjort med politikere i ulike kommuner, er det ingen som ytrer ønske om at ordfører skal ta spesielt hensyn til sin egen politiske fraksjon, og mange ytrer ønske om at ordfører også skal inkludere opposisjonen i politikkutviklingen. Når mange likevel opplever at det ikke skjer, kan det ha ulike årsaker. Det kan selvfølgelig handle om personkjemi, men det kan også skyldes politiske vurderinger og forpliktelse overfor velgerne. Ordførers parti har som regel stor oppslutning i befolkningen og er dermed forpliktet til å forsøke å gjennomføre sitt partis politikk. Det å skulle gjennomføre politikken man er gått til valg på, samtidig som man har ansvar for at alle inkluderes, og for at vedtak skal ha bred politisk støtte og samtidig får rådmannens velsignelse, krever gode lederskapsevner. Skal man få til samarbeid i et landskap av uenighet, er det viktig å inkludere alle, og inkludering tar tid. Samtidig er det den politisk ledelsen sitt ansvar å få ting til å skje. Hvordan man skal balansere inklusjon og effektivitet, prosess og evnen til å fatte beslutninger på rett tidspunkt, går det ikke an å gi noen oppskrift på, men gode ordførere behersker denne balansegangen. Ordførerrollen må utøves i et landskap fylt av spenninger, der praktiske løsninger og prinsipielle avveininger som ikke er forenlige, må forenes, og oppi det hele må det fattes beslutninger.

I kommuner med bred politisk enighet og godt samarbeidsklima har ordfører et lettere utgangspunkt enn i kommuner der konfliktene kanskje er tilspisset eller er blitt personlige. Et tiltak flere kommuner har hatt hell 
med, er at man jobber med måten man snakker til hverandre på - at den er respektfull. Flere politikere trekker frem som positivt at ordfører tar ansvar for at folk snakker ordentlig til hverandre, som denne kommunestyrerepresentanten uttrykker:

[Ordføreren] er veldig ryddig når det gjelder hva som blir tolerert fra kommunestyrets talerstol. Han slår ned på ting tvert - karakteristikker eller at man sier ting om enkeltpersoner. Der ordførere tillater mer, blir det mye mer ufin språkbruk og personkarakteristikker, som gjør at det liksom blir litt utrivelig stemning. Du blir litt lei deg, og så blir du sint, og det kan bidra til at folk ikke tør å ta ordet. (Kommunestyremedlem i norsk kommune)

Videre går det an å designe den politiske prosessen på måter som gjør at forskjeller og uenighet blir tydelig og artikulert, samtidig som de ikke får dominere i alle faser. En måte å gjøre dette på er å dele den politiske prosessen i avgrensede sekvenser. Hvis man klarer å avgrense konflikten til selve valgsituasjonen eller til bestemte temaer, så kan man samarbeide om resten. I noen kommuner får de til dette. For eksempel finnes det i noen kommuner en forventing om at konflikter bare kan få spille seg ut i kommunestyresalen (der debattene kan være harde og til tider ufine), men når kommunestyremøtet er over, er alle privatpersoner igjen og opptrer vennlig og respektfullt overfor hverandre.

En vanlig modell, særlig i mange danske kommuner, men også i en del norske, er at politikerne samarbeider godt på tvers av partier i komiteene de sitter i, mens de i kommunestyresalen tar på seg partipolitikerhatten og er uenige langs forutsigbare, ideologiske skillelinjer. På den måten får man en slags «frontstage» preget av forskjeller og uenighet, mens kompromissene smis på bakrommet og sikrer at politikk faktisk blir utviklet. En forutsetning for at politikerne skal «våge» å fravike partipolitiske skillelinjer, ser ut til å være at pressen ikke er til stede (se kapittel 4). I danske kommuner, hvor kravene til åpenhet er mindre, har man høstet gode erfaringer med å skille mellom diskusjoner i åpne og lukkede fora. Intervjuer vi har gjort med danske lokalpolitikere, gir eksempler på hvordan slike tiltak kan se ut. I Rebild kommune har man for eksempel vedtatt spilleregler for hvordan man som folkevalgt skal kommunisere i 
kommunestyret (på hjemmebane) og ute i offentligheten (på bortebane). Partiforskjeller og konfliktlinjer kan gjerne dominere forhandlingene i kommunestyret, hvor også pressen er til stede, men når de folkevalgte er på utebane på vegne av kommunestyret, forventes lojalitet overfor de beslutningene som kommunestyret har truffet. Videre har de etablert spilleregler for lukkede møter hvor felles idéutvikling står i sentrum (øvingsbanen). Her skal partiforskjeller settes i parentes, og man skal i fellesskap utforske nye løsninger. Tilsvarende er man i kommuner med utstrakt innbyggerinvolvering ofte opptatt av at partipolitiske konflikter skal legges igjen utenfor de arenaene der innbyggerne inviteres inn, for ikke å skremme innbyggerne bort. Mange politikere ser på dette som en mulighet til å diskutere «partifritt» også med andre politikere, og de mener at god politikkutvikling skjer når innbyggerne er til stede, blant annet fordi politikerne «slipper å krangle».

Disse eksemplene viser at det er mulig å påvirke samarbeidsklimaet gjennom institusjonelle virkemidler. Når en konflikt står i fare for å komme ut av kontroll, og debatten blir ufin eller personorientert, kan man demme opp ved å regulere eller lage regler for det politiske spillet. Det kan imidlertid også være behov for å puste liv i lunkne konfliktlinjer. Når forskjellene mellom ulike partier undertrykkes eller blir utydelige, kan det være nødvendig å «puste på» konflikten for å skape mer dynamikk og innovasjon. Dette kan være en nyttig strategi særlig der kommunestyret er blitt for konsensusorientert, konfliktsky eller for lukket i sine posisjoner.

Diskusjonen av konfliktparadokset viser at for mye konflikt og konflikt på gale måter ikke er bra, men bra er heller ikke for mye enighet og enighet på gale måter. Passe mye konflikt kan skape den nødvendige politiske dynamikken som må til for å utforske ulike dagsordener og politiske løsninger. Politiske forskjeller speiler jo mangfoldet i samfunnet, og politikken har redskaper for å handle og prioritere i et landskap preget av ulike behov og ønsker. I norske og danske kommuner har man mange forskjellige institusjonelle ordninger for å kunne diskutere seg frem til enighet, og for å være kreative med hvordan man skal bruke de begrensede ressursene man har til rådighet, på en mest mulig hensiktsmessig måte. Partidemokratiet med sin konfliktorientering, ofte utspilt 
i kommunestyresalen, og konsensusorienteringen i formannskap og komiteer åpner et spenningsfylt rom der nettopp dette er mulig. En forutsetning er imidlertid at politikerne er fleksible og pragmatiske og ikke knytter seg for sterkt til ett handlingsprinsipp. Man kan ikke alltid være partipolitiker - noen ganger må man strekke ut en hånd. Men man kan heller ikke alltid søke enighet. Noen ganger er ikke enighet mulig eller ønskelig av hensyn til velgerne, som faktisk har ulike ønsker og behov.

\section{Referanser}

Aarsæther, N. \& Bjørnå, H. (2016). «Enstemmig vedtatt» - et kritisk blikk på hva som ligger bak kommunenes enighet. Fagbladet samfunn og økonomi, (1), 30-43.

Adams, J. \& Merrill, S. (2009). Policy-seeking parties in a parliamentary democracy with proportional representation: A valence uncertainty model. British Journal of Political Science, 39(03), 539-558.

Berg, R. \& Kjær, U. (2007). Lokalt politisk lederskab. Odense: Syddansk Universitetsforlag.

Habermas, J. (1984). Borgerlig offentlighet. Oslo: Gyldendal.

Hovland, E. (1987). Grotid og glanstid. 1937-1920. I H. E. Næss, E. Hovland, T. Grønlie, H. Baldersheim \& R. Danielsen (Red.), Folkestyre i by og bygd. Norske kommuner gjennom 150 år. Oslo: Universitetsforlaget.

Lantto, J. (2005). Konflikt eller samförstånd? Stockholm: Akademitryck AB.

Lijphart, A. (1984). Democracies: Patterns of majoritarian and consensus government in twenty-one countries. New Haven, CT: Yale University Press.

Lijphart, A. (1999). Patterns of democracy: Government forms and performance in thirty-six countries. New Haven, CT: Yale University Press.

Martinussen, P. (2004). Majority rule in consensual democracies: Explaining political influence in Norwegian local councils, Local Government Studies, 30(3), 303-330. https://doi.org/10.1080/0300393042000310417

Mouffe, C. (2000). The democratic paradox. London: Verso.

Næss, E. H. (1987). Det lokale selvstyrets røtter. Tiden fram til 1837. I H. E. Næss, E. Hovland, T. Grønlie, H. Baldersheim \& R. Danielsen (Red.), Folkestyre i by og bygd. Norske kommuner gjennom 150 år. Oslo: Universitetsforlaget.

Skare, A. (200o). Jo mer lokalpolitikk, dess mindre partipolitikk - Om partienes rolle i lokalpolitikken. I A. Offerdal \& J. Aars (Red.), Lokaldemokratiet. Status og utfordringer. Oslo: Kommuneforlaget. 
Skoog, L. (2018). Political conflict. Dissent and antagonism among political parties in local government. Doktoravhandling. Göteborg: Förvaltningshögskolan, Göteborgs universitet.

Skoog, L. \& Karlsson, D. (2015). Politiska konflikter och marknadisering utmaningar för politiska ledare? I N. Aarsæther og K. Mikalsen (Red.), Lokalpolitisk lederskap i Norden (s. 112-147). Oslo: Gyldendal Akademisk.

Skoog, L. \& Karlsson, D. (2018). Causes of party conflicts in local politics. Politics, $38(2), 182-196$.

Svara, J. H. (2003). Effective mayoral leadership in council-manager cities: Reassessing the facilitative model. National Civic Review, 92(2), 157-172.

Sørhaug, H. C. (1984). Totemisme på norsk - Betraktninger om den norske sosialdemokratismes vesen. I A. M. Klausen (Red.), Den norske voremåten. (s. 61-87). Trondheim: J. W. Cappelens Forlag. 


\section{Kompromiss er ofte den beste løsningen}

Tekst: Marte Winsvold. Intervju foretatt 16. oktober 2019.

Selv om det skal vere konflikter i politikk, er den beste losningen ofte et kompromiss. Ordforerens rolle er å hjelpe til med å finne losninger som alle kan stille seg bak.

Jonni Solsvik, tidligere ordfører i Andøy kommune

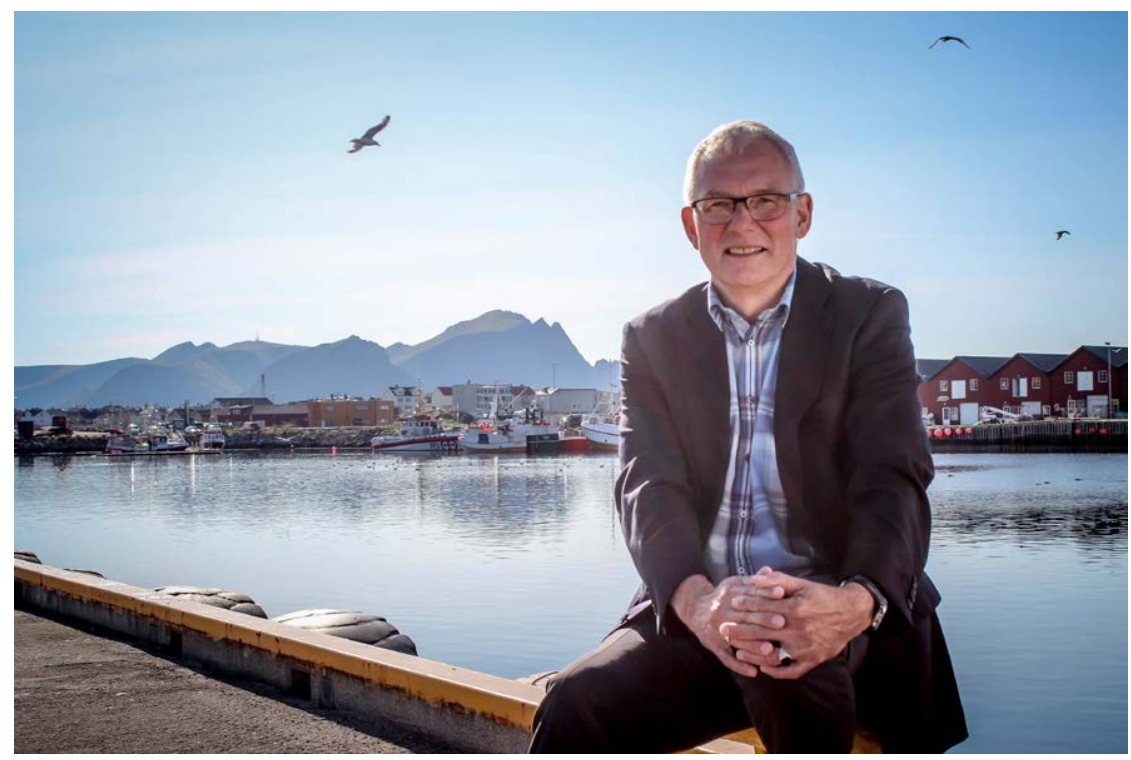

KOMPROMISSER: «Skal man få et levende lokaldemokrati, så mener jeg oppriktig at ethvert kompromiss i vanskelige saker er mye bedre for lokaldemokratiet og for samfunnet enn at man har en part som får alt sitt igjennom», sier tidligere ordfører i Andøy kommune, Jonni Solsvik. (Foto: Svein Terje K. Eliassen, God Strek. Bildet er gjengitt med tillatelse og omfattes ikke av bokens lisens.) 
I kommunepolitikken må folkevalgte som kanskje er veldig uenige, samarbeide om å finne felles politiske løsninger. Solsvik, som var ordfører for Andøy kommune i fem perioder, mener likevel at konflikt er en viktig del av politikken.

«Du får ikke dynamikk i politikken hvis det ikke er konflikter. Det skal være konflikt, det er det som er hensikten. Både i kommuner med formannskapsmodell og parlamentarisme, så er det konflikten som er utgangspunktet. Men skal man få et levende lokaldemokrati, så mener jeg oppriktig at ethvert kompromiss i vanskelige saker er mye bedre for lokaldemokratiet og for samfunnet enn at man har en part som får alt sitt igjennom. Jeg vil påstå at i langt over nitti prosent av sakene så er det faktisk kompromisset som er den beste løsningen», sier den tidligere ordføreren.

Solsvik mener at det særlig i de vanskelige sakene med stor uenighet er viktig å finne et kompromiss. «Ta for eksempel budsjettet, som alltid er vanskelig. Der etterstrebes mest mulig enighet om de store linjene, selv om utgangspunktet er uenighet. Og så har man jo selvfølgelig uenighet, og hvis den blir veldig sterk, så må man bruke demokratiet - flertallets rett til å bestemme - til å avgjøre hvordan dette skal være. Men at man hele tiden er på jakt etter å finne en felles løsning på vanskelige saker, det tror jeg gir det beste resultatet», sier han.

\section{Ordførerens rolle}

Solsvik har sittet som ordfører med rent flertall bak seg, og han mener at det i en slik situasjon er spesielt viktig å involvere flest mulig. «Du skal ikke bruke makta på en måte som gjør at resten av det politiske miljøet, de som ønsker å stille opp for å være med å utvikle lokalsamfunnet, føler at deres oppfatning egentlig ikke har betydning», sier han. «I en konfliktsituasjon hvor det er forskjellige meninger om en viktig sak, må man som ordfører åpne for å drøfte om det finnes en felles grunn, et kompromiss som gjør at alle føler at de har vært med å påvirke resultatet.» Her har ifølge Solsvik ordføreren en helt sentral rolle i å skape kompromisser i konfliktsaker, og han understreker at slike kompromisser gjerne kan utfordre ordførerens eget partisyn. 


\section{Kompromiss er ikke alltid mulig}

Solsvik erkjenner at det i enkelte saker kan være umulig å finne et kompromiss. Han mener likevel at det ligger stor verdi i å forsøke. «Hvis man etter et hederlig forsøk til slutt må konkludere med at det ikke går, og at man dermed får en votering som gjør at resultatet ikke blir påvirket av alle, da blir det akseptert på en helt annen måte enn når man som ordfører er opptatt av å få gjennom bare sitt parti sitt syn», sier han.

Særlig er dette viktig i saker som oppleves negativt, ifølge Solsvik. Han bruker skolenedleggelser som eksempel:

«Skolenedleggelser er fryktelig vanskelig å håndtere. I de sakene er det spesielt viktig å se om man kan finne kompromisser som gjør at folk kan si at 'egentlig så har jeg mitt standpunkt, men jeg finner det likevel best for mitt lokalsamfunn at vi er med på å skape en god løsning'. Dette er etter min mening helt fundamentalt», sier Solsvik, «det er her lokaldemokratiet har sin store styrke».

Han vet at ikke alle politikere er like innstilt på å finne kompromisser. «Vi har selvfølgelig noen tilfeller hvor ordførere og andre er skrudd sammen slik at de ikke ønsker å ha det på den måten, de ønsker å kjøre en tøff linje opp mot de som har andre meninger enn dem selv. Det tror jeg lokalsamfunnet ikke er tjent med», sier han og fortsetter: «Jeg pleier å si det at en av de viktigste funksjoner en ordfører har, det er faktisk å skape et godt samspill og et godt politisk arbeidsmiljø. Ordførerens rolle er å være ordfører for alle, og da må han også involvere alle. Det betyr ikke at man er enig med alle, det betyr at det å være ordfører handler om å etablere en forståelse, en samhandling hvor alle opplever at deres oppfatning har betydning.»

\section{Bjellesau}

Solsvik er opptatt av at de som ønsker å være med i politikken, skal føle seg inkludert. Som ordfører er det særlig viktig å sørge for at de politikerne som tilhører opposisjonen, opplever at de kan være med å bidra.

«Det er en stor utfordring når mennesker som egentlig har lyst til å være med å bidra i samfunnsutviklinga, opplever at de møter et politisk 
system hvor de for eksempel er i opposisjon og opplever å ikke ha noen innvirkning, sier Solsvik. «Med tanke på rekruttering til politisk arbeid, så vil jo det ikke være så motiverende. Politikk er ingen popularitetskonkurranse, det er faktisk folk som blir valgt for å ta beslutninger på vegne av befolkningen. Da er det viktig at man sørger for å få en best mulig samhandling, og det er ordføreren som her er bjellesauen. Hvis han ikke går foran, så blir det heller ikke gjort, og da får du lett konflikter.»

\section{Synliggjøre uenighet}

Solsvik mener det er viktig at der det er uenighet, må den uenigheten som finnes, bli gjort synlig. Han er opptatt av at man må få frem de politiske konfliktene, og at også ordførere må ha en mening og kunne gi uttrykk for denne. Samtidig ser han det som ordførerens rolle å få folk til å samarbeide på tross av uenighet, og å dempe konfliktnivået etter at beslutningen er tatt. Det tror han er nødvendig for at lokaldemokratiet skal fungere.

«Jeg mener oppriktig at ordførerrollen, den handler om å være samlende. Da er det klart at møter man saker hvor det ikke er mulig, så skal man selvfølgelig markere det og stå for det synet man primært har. Men at det er en enighetskultur, jeg tror det er styrken til lokaldemokratiet. Samarbeid er kanskje det som er mest effektivt som politisk virkemiddel for å unngå populisme, også i lokalpolitikken», sier Solsvik.

Solsvik mener altså at både konflikt og samarbeid har en plass i politikken, og at man må ta den tiden som trengs for å klare å balansere godt mellom de to:

«Ordføreren som satt før meg, sa at det viktigste du gjør, er å være på jakt etter konflikter, vise frem konflikter, men samtidig skal du være på jakt etter de felles løsningene. Det er en og samme sak. For å finne felles løsninger så må konfliktene på bordet, og det må være stor grad av involvering. Lokaldemokratiet tar tid. Det er også en styrke. Det er demokratiet. Noen ganger tar det lang tid, men den tiden må vi verne om.» 


\title{
Administrasjonsparadokset Farvel til timeglassmodellen?
}

\author{
Christian Lo
}

Nord universitet

Signy Irene Vabo

Universitetet i Oslo

\begin{abstract}
In this chapter, we discuss the consequences of what we have coined as the "administrative paradox". The administrative paradox denotes the tensions that occurs when the normative expectation that political leaders should have a leading role in policy processes meets the practical reality that administrative actors are often the ones to set the political agenda. In the chapter, we discuss the modern-day relevance of classical ideas about the relation between politics and administration and, also, explore some recent attempts made by Norwegian municipalities to innovate political leadership in ways that affect this relation. A central theme in our discussion is the consequences of the so-called "hour-glass model" that describes a separation of politics and administration where the two spheres are joined through the roles of the mayor and the chief municipal executive. While the hour-glass model has had a profound impact on the organization of political and administrative leadership in Norwegian municipalities for close to three decades, we argue that the model is now due for a replacement. In its place, we suggest an alternative model that provides a more accurate description of how political leaders maintain a wider set of interfaces and that admits politicians a role also in the early phases of policy development. We have called this alternative model the "cogwheel-model". In a brief and subsequent chapter, a Norwegian Chief Executive reflects on the interplay between politics and administration.
\end{abstract}

Keywords: elected representatives, local government, political leadership, politicians and administrators, democratic innovations

Sitering av denne artikkelen: Lo, C. \& Vabo, S. I. (2020). Administrasjonsparadokset. Farvel til timeglassmodellen?. I A. Røiseland \& S. I. Vabo (Red.), Folkevalgt og politisk leder (Kap. 3, s. 62-94). Oslo: Cappelen Damm Akademisk. https://doi.org/10.23865/noasp.80.ch3

Lisens: CC BY-ND 4.0. 


\section{Introduksjon}

Ja, du kan jo ta det i forhold til en sak. En sak sine bevegelser. Fra den unnfanges til den utredes, innstilles og behandles. Så er det jo et klart skille i tid.... I det oyeblikket en rådmann har avgitt sin innstilling, så er det politikk. Og da må jo på en måte rådmannen og administrasjonen forholde seg til de beslutningene som blir tatt. Selv på tvers av det administrasjonen har anbefalt. I et ytterliggående tilfelle.

Rådmann i norsk kommune

Dette sitatet kommer fra et intervju med en erfaren rådmann som ble spurt om å redegjøre for skillet mellom politikk og administrasjon. Rådmannen skisserte en ryddig og kronologisk oppgavefordeling: Administrasjonen tilrettelegger for politiske beslutninger, de folkevalgte politikerne tar beslutningene, og administrasjonen utfører det politikerne har besluttet. Selve beslutningen er den sentrale politiske handlingen, mens administrasjonen eksplisitt skal avstå fra å ta del i selve beslutningen. Og gjennom den hierarkiske ordenen som beskrives her, er det de folkevalgte som utøver politisk lederskap, mens administrasjonens rolle er å tilrettelegge for de politiske prosessene og lojalt utføre det de folkevalgte beslutter. Det sistnevnte skal gjennomføres selv om de skulle være aldri så uenige «i et ytterliggående tilfelle».

Fremstillingen er på mange måter riktig og rimelig, og svært typisk for hvordan forholdet mellom politikk og administrasjon vanligvis oppfattes - både i og utenfor rådhuset. Politikkutvikling forutsetter ofte en innsikt og fagkunnskap som de folkevalgte ikke har forutsetninger for å tilegne seg i den bredden av saker de forventes å engasjere seg i. De er derfor avhengig av administrativ tilrettelegging for å kunne fatte gode beslutninger. Samtidig hviler den demokratiske legitimiteten på at det er de folkevalgtes vurderinger og beslutninger som er førende. Det er derfor avgjørende at administrasjonen forholder seg mest mulig nøytral til de politiske beslutningsprosessene. 
I Norge er forholdet mellom politikk og administrasjon gjerne blitt illustrert med den såkalte timeglassmodellen, som har fått normativt fotfeste i mange norske kommuner. Modellen oppsto i kjølvannet av endringene i kommuneloven av 1992, og den ble definert gjennom at administrasjonen ble samlet under én sjef. I den nye loven fikk dermed administrasjonen kun én stemme overfor politikerne. Ideen var i sin tid at rådhuset burde organiseres slik at all kontakt mellom politikere eller politiske organer og kommunens administrativt ansatte eller etater og enheter ble konsentrert om rådmannen. I den rendyrkede varianten av modellen, som er illustrert med innsnevringen i timeglasset, skulle all kommunikasjon mellom politisk og administrativ del av organisasjonen skje mellom ordfører og kommunedirektør ${ }^{2}$ (Kleven, 1997:65).

Det vi har valgt å kalle et «administrasjonsparadoks» i norsk lokal politikk, er nært knyttet til hvordan timeglassmodellen regulerer forholdet mellom politikk og administrasjon i norske kommuner. Paradokset består i at forestillingen om et strengt hierarkisk og dikotomisk skille mellom den politiske og den administrative sfæren er et direkte misvisende utgangspunkt for å beskrive de forventninger vi har til lokalpolitikerne. De fleste vil for eksempel være enige $i$ at vesentlige og førende deler av politikkutformingen foregår $i$ de tidlige fasene - før beslutningene $i$ de politiske behandlingsorganene finner sted (se kapittel 1). Et konkret uttrykk for disse forventingene finner vi blant annet i det arbeidsheftet KS tilbyr som del av «folkevalgtprogrammet», der det slås fast at «[1]ederrollen innebærer å tenke strategisk, være visjonær, finne nye løsninger og få aksept for løsningene» (Kommunenes Sentralforbund, 2018, s. 23).

En kronologisk oppgavefordeling hvor administrasjonen forbereder saker, politikerne fatter beslutninger og administrasjonen iverksetter disse, gir ikke nødvendigvis rom for at de folkevalgte skal kunne involvere seg i de fasene av politikkutformingsprosessen der situasjonen tolkes og problemer identifiseres, og der disse blir utgangspunkt for tiltak i form av ny eller endret politikk. Ettersom det å sette saker på dagsordenen gjerne oppfattes som en politisk handling, kan også administrasjonens

2 Kleven brukte selvsagt betegnelsen «rådmann». Jf. note 1 i kapittel 1 benytter vi imidlertid den kjønnsnøytrale betegnelsen «kommunedirektør» i denne boken, uavhengig av hva som fremkommer i den originale konteksten. 
nøytralitetsnorm utfordres - spesielt dersom kontroversielle politiske saker drives frem uten de folkevalgtes innflytelse. Samtidig kan fravær av politisk ledelse virke handlingslammende på administrasjonen, som gjerne søker å unngå å bli oppfattet som aktiv part i typisk politiske saker.

Dessuten foregår politiske prosesser i praksis sjelden i slike ryddige, lineære og tidsinndelte prosesser som rådmannen sitert i starten av dette kapitlet, skisserer. Særlig vil saksforberedelsen i omfattende og kontroversielle saker ofte bestå av en serie ulike utredninger og beslutninger, også underveis i iverksettingen. Fasene blandes altså sammen, og beslutninger av betydning for politikkutfallet skjer i alle faser. Utviklingen av politikken blir på den måten en langt mer «rotete» prosess enn en forenklet modell gir inntrykk av (se f.eks. Lindblom,1965; March \& Olsen, 1979; Svara, 1998; Shore \& Wright, 2011).

Realitetene taler derfor for et kontinuerlig samspill mellom politikk og administrasjon, hvor det samhandles i alle faser av politikkutviklingen. Dette gjelder særlig i prosesser hvor kommunen er avhengig av samarbeid og koordinasjon med aktører og ressurser som befinner seg utenfor de politiske organenes formelle beslutningsmyndighet. Slike situasjoner krever et større repertoar av styring og ledelsestilnærminger - ut over rollen som beslutningstakere i kommunestyret (Torfing, Peters, Pierre \& Sørensen, 2012, Røiseland \& Vabo, 2016). Derfor vil det ikke alltid være mulig eller ønskelig å opprettholde et skille mellom politikk og administrasjon gjennom å avstå fra samhandling. Snarere må en atskillelse baseres på konkrete regler for samhandling, som definerer rollenes oppgaver og funksjoner.

«Administrasjonsparadokset» består altså i at vi på den ene siden, normativt sett, ønsker at det er lokalpolitikerne som skal sette saker på agendaen, formulere problemer og diskutere seg frem løsninger. Alternativet er at dagsordenen i stor grad settes av kommunens administrasjon. Samtidig fordrer et slikt engasjement at politikerne samhandler - i mange omganger - med administrasjonen. Men det vil på den andre siden gjøre det vanskeligere å opprettholde det helt nødvendige skillet mellom politikk og administrasjon. Dette skillet er grunnleggende i vårt demokratiske styresett, som er basert på representativitet. De folkevalgte står til ansvar overfor innbyggerne. For at de skal kunne gjøre det med troverdighet, må de styre og kontrollere så vel egen administrasjon som 
etablerte selskaper og ulike typer samarbeid. Det er jo resultatene disse utøvende organisasjonene produserer, som innbyggerne bedømmer de folkevalgte ut fra ved neste valg. Normativt sett bør derfor politikerne sitte i førersetet, og det bør være et klart skille mellom den rollen politikerne spiller, og den rollen administrative ledere og ansatte i kommunen spiller.

I det videre skal vi først diskutere det normative tankegodset som ligger bak skillet mellom politikk og administrasjon. Vi diskuterer så hva som er særegent ved den norske modellen for å organisere forholdet mellom politikk og administrasjon, og vi argumenterer for at timeglassmodellen bør byttes ut, for eksempel med det vi har valgt å kalle «tannhjulmodellen», som bedre beskriver dagens praksis. Deretter gir vi noen eksempler på hvordan norske og danske kommuner har forsøkt å styrke politikernes rolle i tidligere faser av politikkutviklingsprosessen gjennom å endre oppgavefordelingen mellom politikk og administrasjon. Med bakgrunn i dette understreker vi avslutningsvis betydningen av det lokalpolitiske mulighetsrommet når oppgavefordelingen, og dermed skillet mellom politikk og administrasjon, skal institusjonaliseres i egen kommune.

\section{Det normative utgangspunktet}

For å gi en forståelse av hvorfor det er nødvendig å opprettholde et skille mellom politikk og administrasjon, skal vi ta utgangspunkt i hvordan dette skillet begrunnes i klassisk byråkratiteori. Til tross for at det dikotomiske skillet mellom politikk og administrasjon går lenger tilbake, både som idé og som praksis, forbindes det i dag først og fremst med Woodrow Wilsons (1856-1924) normative byråkratiteori (Wilson, 1887) og Max Webers (1864-1920) idealtypiske fremstilling av byråkratiet (Weber, 1919/1971). Det er påfallende mange likheter mellom de to samtidige teoretikerne, noe som har sammenheng med at de begge skrev med utgangspunkt i den samme europeiske byråkratitradisjonen (Sager \& Rosser, 2009). Som det er blitt påpekt når det gjelder Weber, er kanskje hans beskrivelser av byråkratiets kjennetegn blant de minst originale av hans bidrag, ettersom mye av essensen var hentet fra samtidig tysk forvaltningslære (Byrkjeflot, 2018). Samtidig er det også noen interessante 
forskjeller i Wilsons og Webers beskrivelser som delvis avspeiler de ulike kontekstene de skrev i, og ulike vektlegginger i begrunnelsene for en atskillelse mellom politikk og administrasjon.

For den amerikanske statsviteren (og etter hvert statsmannen) Wilson hadde interessen for den europeiske byråkratitradisjonen bakgrunn i et ønske om å reformere en lite utviklet amerikansk offentlig administrasjon (Cuff, 1978). Selv om han anerkjente behovet for å tilpasse ideene til amerikanske forhold, var inspirasjonen hentet fra Europa. I Wilsons tid var amerikansk administrasjon preget av en åpen politisk rekruttering til embetene, hvor ledende tjenestemenn ble avkrevd sterk politisk lojalitet og gjerne ble byttet ut i følge med sine politiske ledere (Overeem, 2005). For Wilson var det derfor en normativ målsetting å erstatte det amerikanske «spoils-systemet» med et rasjonelt og selvstendig byråkrati med utgangspunkt i de regelbaserte og meritokratiske prinsippene han forbandt med den europeiske tradisjonen (Sager \& Rosser, 2009). I den grad Wilson var opptatt av et dikotomisk skille mellom politikk og administrasjon, handlet dette derfor om å etablere et mer selvstendig byråkrati gjennom å holde politikken ute av administrasjonen (Overeem, 2005):

Av aller størst viktighet er den etablerte sannheten som allerede, og heldigvis, har blitt påpekt av våre reformatorer i embetsverket, nemlig at administrasjon ligger utenfor politikkens sfære. Administrative spørsmål er ikke politiske spørsmål. Selv om politikken fastsetter administrasjonens oppgaver, så bør ikke dens embeter gjøres til gjenstand for politisk manipulasjon. (Wilson, 1887 , s. 210, vår oversettelse)

Webers idealtypiske beskrivelser hadde et langt mindre normativt utgangspunkt, og de var først og fremst utviklet med analytiske og komparative formål. Samtidig hadde Weber et ambivalent og kritisk syn på det rasjonelle byråkratiets fremvekst og dets potensielt dehumaniserende effekt (Byrkjeflot, 2018; Fivelsdal, 1971). Han argumenterte derfor for et sterkt politisk lederskap som kunne begrense akkumulasjon av makt i byråkratiet og en utvikling i retning av et embetsmannsvelde (Cuff, 1978). For Weber handlet altså skillet mellom politikk og administrasjon i stor grad om å holde administrasjonen ute av politikken (Overeem, 2005). Det 
betydde konkret at administrasjonen skulle avstå fra å delta i kampen rundt de politiske beslutningene:

Den ekte embetsmann ... skal etter sitt egentlige rykte ikke drive politikk, men «forvalte», og fremfor alt forvalte upartisk. ... «Sina ira et studio», uten vrede og forutinntatthet skal han røkte sitt embete. Han skal nettopp ikke gjøre det politikerne, partiførerne og deres tilhengere må, nemlig kjempe. [...] Embetsmannens ære ligger i evnen til, trass personlig overbevisning, å utføre en ordre på den befalendes ansvar, like samvittighetsfullt som om ordren svarte til hans egen oppfatning av saken. (Weber, 1919/1971, s. 22)

Det er viktig å merke seg at for Weber innebar ikke administrasjonens objektivitetsplikt noe personlig lojalitetsforhold til de rådende politikerne. Han hadde, som Wilson, også klare motforestillinger mot den typen «spoils-system» som kjennetegnet (og delvis kjennetegner) amerikansk byråkrati. Det kan settes spørsmålstegn ved om et slikt system i det hele tatt utgjør et moderne byråkrati, i Webers forstand. Weber fremhevet snarere at administrasjonens uavhengighet var forankret $i$ en lojalitet til lover, prosedyrer og prinsipper. På denne måten vil en uavhengig administrasjon sikre byråkratiets "permanente karakter», hvor «et rasjonelt ordnet embetssystem fungerer knirkefritt videre i fiendens hånd ... fordi alle de delaktige, fremfor alt fienden selv, har en vital interesse av at systemet fungerer» (Weber, 1922/1971, s. 127).

Det å skille mellom politikk og administrasjon skal altså på den ene siden begrense byråkratiets politiske innflytelse og dermed forhindre rådmannsvelde, og på den andre siden skal det imøtekomme en for sterk politisk innflytelse over administrasjonen, noe som vil kunne medføre klientelisme og at administrasjonen blir et middel for å oppnå politisk makt. For å unngå begge disse fallgruvene er det avgjørende at byråkratiet forholder seg til administrative prinsipper - basert på lover, prosedyrer og normer - som både begrenser deres makt og sikrer deres uavhengighet. Det er viktig å merke seg at atskillelsen ikke nødvendigvis handler om fravær av kontakt, men snarere om fordeling av roller, makt og funksjoner mellom politikerne og administrasjonen. 


\section{Institusjonalisering av skillet mellom politikk og administrasjon}

Det finnes altså gode begrunnelser for å holde fast ved et skille mellom politikk og administrasjon. Samtidig vet vi at i praksis lever ikke byråkrater og politikere i separate sfærer - verken nasjonalt eller lokalt (Aberbach, Putnam \& Rockman, 1981, s. 260; Svara, 2014). Mange studier, både internasjonale og nasjonale, viser ordførere og administrative toppledere som gjennomgående opptrer som partnere i den kommunale ledelsen. Relasjonen mellom dem er karakterisert av interaksjon, gjensidig avhengighet og delt innflytelse. Konflikter søkes unngått, og i de aller fleste tilfeller evner politisk og administrativ ledelse å balansere ulike hensyn på en fleksibel måte (se f.eks. Aberbach, Putnam \& Rockman, 1981; Jacobsen, 1996; Selden, Brewer \& Brundney,1999; Mouritzen \& Svara, 2002; Svara, 2006; 2014; Peters, 2009; Willumsen, 2015; Aarsæther, Willumsen \& Buck, 2015).

Selv om samarbeidet i praksis alltid vil være tett, ivaretas det grunnleggende behovet for å skille politikeres og administrativt ansattes funksjoner og roller på ulike måter i ulike land. I internasjonale sammenlikninger av kommunesystemer er det grunnleggende spørsmålet hvem sjefen i rådhuset er. I det videre skal vi først sammenlikne den norske rådhusmodellen med hvordan rådhuset er organisert $i$ andre europeiske land - spesielt i Danmark. Deretter redegjør vi for timeglassmodellen og bakgrunnen for måten skillet mellom politikk og administrasjon er institusjonalisert på i norske rådhus. Til slutt argumenterer vi for at timeglassmodellen bør byttes ut, og vi lanserer den alternative tannhjulmodellen.

\section{Skillet mellom politikk og administrasjon i Norge og Danmark}

De politisk-administrative systemene i ulike land sammenliknes gjerne langs en horisontal dimensjon som omfatter maktfordelingen i relasjonen mellom ordfører, kommunestyre og administrasjon (Mouritzen \& Svara, 2002; Lidstrøm, Baldersheim \& Corpus et al., 2016). De modellene som benyttes i litteraturen, gir en forenklet, men likevel klargjørende innsikt i forskjellene mellom kommunesystemene i Norge og Danmark. 
Danmark plasseres i det som kalles komitéledermodellen, hvor det politiske lederskapet er individuelt, og ordføreren er den politiske lederen. Men hun har ikke nødvendigvis flertall i kommunestyret, og hun deler utøvende myndighet med andre. Noe utøvende myndighet ligger til politiske organer (som økonomiutvalget og andre politiske utvalg), og noe ligger til øverste administrative leder. I motsetning til dette oppfattes det norske politisk-administrative systemet å likne mest på den administrative modellen, som innebærer at den kommunale administrative lederen ansettes av kommunestyret og har den utøvende myndigheten. Ordføreren leder kommunestyret, men har formelt en svak rolle (Mouritzen \& Svara, 2002, s. 66-67; Mikalsen \& Bjørnå, 2015). Den norske politiskadministrative modellen skiller seg altså betydelig fra den danske. Mens det norske systemet beskrives som administrativt dominert - hvor kommunedirektøren har full rådighet over administrasjonen - så innebærer det danske systemet en betydelig sterkere politisk ledelse i utøvelse og implementering av politikk. Det politiske lederskapet er individuelt forankret, og borgermesteren er definitivt den politiske lederen, selv om hun ikke behøver å ha flertall i kommunestyret. Den danske borgermesteren deler utøvende myndighet med økonomiutvalget og øverste administrative leder, men har formelt og de facto rollen som administrativ leder for forvaltningen. Hun har likevel ikke all makt over administrasjonen, i den forstand at hun ikke kan kaste ut øverste administrative ledelse etter eget forgodtbefinnende - som tilfellet er i mange europeiske land med en sterkere ordfører (Lidstrøm et al., 2016).

Det som videre skiller funksjonsfordelingen mellom politikk og administrasjon i de to landene, er den norske kommunedirektørens ansvar for at saker som legges frem for politisk behandling, er forsvarlig utredet. Før endringene i kommuneloven av 1992 var det ordføreren som hadde innstillingsmyndigheten (Kommunenes Sentralforbund, 1995, s. 33). Sammenliknet med det danske systemet, der dette ansvaret ligger hos borgermesteren, har vi sett at kommunedirektøren tillegges en betydelig rolle i det norske systemet, i alle fall formelt. I motsetning til tidligere er det imidlertid formannskapet - og ikke kommunedirektøren - som skal legge frem budsjettet for kommunestyret i det norske systemet. Og hvilke saker og alternativer som utredes i saker som kommer på den politiske 
dagsordenen, vil antakelig i praksis avtales i møter mellom kommunedirektøren og den norske ordføreren.

Data viser at forskjellene i politisk-administrativ modell også gir seg konkret uttrykk i hvordan norske og danske kommunestyrepolitikere beskriver sine relasjoner til andre sentrale aktører eller aktørgrupper, jf. tabell 3.1.

Tabell 3.1 Kontaktmønster for norske og danske kommunestyrepolitikere, 2018. Prosent $\mathrm{N}_{\mathrm{DK}}=705, \mathrm{~N}_{\mathrm{NO}}=3332$ ). Kilde: se appendiks.

\begin{tabular}{|l|r|r|r|r|r|r|}
\hline & \multicolumn{2}{|c|}{$\begin{array}{r}\text { Kontakt med } \\
\text { kommune- } \\
\text { administrasjonen }\end{array}$} & $\begin{array}{r}\text { Kontakt med } \\
\text { politikere fra andre } \\
\text { partier }\end{array}$ & \multicolumn{2}{|}{$\begin{array}{r}\text { Kontakt med } \\
\text { innbyggere }\end{array}$} \\
\hline & Norge & Danmark & Norge & Danmark & Norge & Danmark \\
\hline Daglig eller ukentlig & $\mathbf{3 5 \%}$ & $\mathbf{6 7} \%$ & $\mathbf{4 3} \%$ & $\mathbf{7 0 \%}$ & $\mathbf{6 7} \%$ & $\mathbf{8 1} \%$ \\
\hline Månedlig/sjeldnere & $65 \%$ & $33 \%$ & $57 \%$ & $30 \%$ & $33 \%$ & $19 \%$ \\
\hline & $100 \%$ & $100 \%$ & $100 \%$ & $100 \%$ & $100 \%$ & $100 \%$ \\
\hline
\end{tabular}

${ }^{1}$ Ordlyden i spørsmålet som ble stilt, var: «Som folkevalgt, omtrent hvor ofte har du kontakt med følgende grupper om politiske saker i kommunen: daglig, ukentlig, månedlig, en gang i året eller sjeldnere, aldri».

Som det kommer frem av tabellen, er det betydelig forskjell i omfanget av kontakten kommunestyrepolitikere (inkludert ordførere) oppgir at de har med så vel innbyggere som andre politikere og kommunens administrasjon. Dette gjelder også dersom vi kontrollerer for størrelse og kun sammenlikner kommuner med flere enn 20 ooo innbyggere i begge land (det finnes svært få kommuner med færre enn 20 ooo innbyggere i Danmark). Ser vi på kontakten med kommuneadministrasjonen, har 67 prosent av de danske politikerne daglig eller ukentlig kontakt, mens kun 35 prosent av de norske kommunerepresentantene har så hyppig kontakt med administrasjonen. Dette kan selvsagt ha med kommunestyrenes størrelse å gjøre, ettersom det gjennomgående er betydelig flere representanter i norske kommunestyrer enn i danske. Det kan også ha å gjøre med at det er flere heltidspolitikere i de relativt store danske kommunene, sammenlignet med de norske, som i gjennomsnitt er betydelig mindre. Uansett angir dette at det er tettere kontakt mellom de som nå en gang sitter i kommunestyret og kommunens administrasjon i Danmark, sammenlignet med i Norge. Det er nærliggende å tolke dette som utslag av et 
administrativt dominert kommunesystem i Norge, definert i ideen om timeglassmodellen, som vi omtaler i det videre.

Ser vi videre på kontaktmønsteret, finner vi betydelige forskjeller mellom landene også når det gjelder kommunestyrepolitikernes kontakt med politikere fra andre partier og med innbyggerne. I begge tilfeller er de danske kommunestyrepolitikerne betydelig åpnere mot omgivelsene enn de norske. Det betyr at den norske politisk-administrative modellen i betydelig mindre grad enn den danske fører til kontakt mellom politikerne og andre aktører. Igjen kan dette ha med det større omfanget av heltidspolitikere i dansk lokalpolitikk å gjøre. Men sammenliknet med de danske kommunestyrepolitikerne er de norske mer internt orientert. Dette tyder på at administrasjonen har en sterk stilling; sammenliknet med Danmark er de folkevalgte i norske kommunestyrer antakelig mer avhengig av de sakspapirene som administrasjonen legger frem.

\section{Den norske timeglassmodellen}

Timeglassmodellens rendyrking av skillet mellom politikk og administrasjon - hvor utgangspunktet er at politikerne ikke skal kontakte administrativt ansatte uten å gå via ordføreren, som i sin tur går til kommunedirektøren, som igjen formidler videre i administrasjonen - kan i dag oppfattes som en underlig idé. En praksis som skiller de to sfærene på denne måten, er ikke mulig å opprettholde i de aller fleste norske kommuner, som er relativt små. I små kommuner må både politisk og administrativt involverte nødvendigvis ha mange hatter på. Men samtidig må de være bevisst på hvordan de sjonglerer med hattene (Lo, 2018). For å forstå ideen om en timeglassmodell som norm for omgangen mellom politikerne og administrasjonen må den ses i sin historiske kontekst.

Timeglassmodellen var et svar på utfordringene knyttet til det som i 1980-årene ble oppfattet som «samrøre» mellom politikk og administrasjon i kommunene (Vabo, 2003). Med grunnlag i den uttrykte kritikken av byråkratiets sterke rolle som kom med New Public Managementtankegodset, var tanken at politikernes styringsrolle måtte styrkes. Dette preget reformarbeidet i Norge så vel som i våre naboland på den tiden (Kleven, 1997; Montin, 1997; Berg, 2000; Vabo, 2000). Utgangspunktet 
var at den politiske ansvarligheten burde styrkes gjennom å tydeliggøøre politikken, i den hensikt å styrke det representative demokratiet (Aarsæther \& Vabo, 2002). Oppfatningen var at administrasjonens rolle var blitt for dominerende, og at politikerne hadde blitt mindre sentrale enn de burde være i kommunepolitikken. Intensjonen med endringene var blant annet et ønske om å flytte lokalpolitikernes oppmerksomhet fra det interne til det eksterne; fra å være sektoradministrasjonens forsvarere til å bli mer aktive i håndteringen av befolkningens ulike krav og behov.

Spørsmålet er hvordan intensjonene om økt politisk ansvarlighet, effektivitet og helhet i politikken kom til uttrykk i de nye måtene å organisere det politiske arbeidet på. Et mulig utgangspunkt for å beskrive dette er den sektororienterte hovedutvalgsmodellen, som ved starten av 1990-tallet var etablert i så å si alle norske kommuner. Utvalgsorganiseringen var da regulert $\mathrm{i}$ en omfattende særlovgiving som påla kommunene å ha utvalg på blant annet sosialområdet og skoleområdet (Vabo \& Stigen, 2000; Vabo, 2003). Hovedutvalgsorganiseringen bidro til en tett kopling mellom politikerne og administrasjonen innenfor mer eller mindre uavhengige sektorer - gjerne innenfor det helse- og sosialpolitiske området, utdanning, teknisk og kultur. Både kommunelovutvalget og Kommunenes Sentralforbund argumenterte imidlertid for at et tydelig skille mellom politikk og administrasjon ville være viktig for å hindre at omverdenen oppfattet de to sfærene som så involvert i hverandre at politikerne ikke kunne stilles til ansvar. Samtidig ble det vist til at denne sektororienterte måten å arbeide på i stor grad vred den politiske oppmerksomheten mot håndtering av praktiske og løpende (enkelt)saker knyttet til den daglige driften av sektorens tjenester og håndteringen av dens brukere. Dette ble oppfattet som lite effektivt, og idealet var at slike anliggender skulle overlates til administrasjonen. Det ble fremholdt at overordnet styring av prinsipper - eller målstyring - ville gi politikerne bedre kontroll med administrasjonen fordi politikerne dermed ville bli mer resultatorientert, rette oppmerksomheten mot viktige og prinsipielle spørsmål og dermed gjøre mer strategiske overveielser (Kommunenes Sentralforbund, 1989, s. 18-26; NOU 1990: 13, s.97-99).

I forarbeidene til kommuneloven av 1992 er søkelyset rettet hovedsakelig mot å skille mellom politiske og administrative oppgaver. Det 
uttrykkes blant annet at «De folkevalgte organer bør gjennom sine vedtak bestemme hva som skal gjøres, mens administrasjonen bør gis stor grad av handlefrihet til å bestemme hvordan oppgavene løses og slik at de folkevalgte organer fører kontroll med at utførelsen er i tråd med de vedtak som er truffet» (NOU 1990: 13, s. 137). Det trekkes altså et skille mellom mål og virkemidler, hvor politikerne forutsettes å etablere mål for virksomheten, og administrasjonen skal konkretisere og iverksette disse. Ideen var at administrasjonssjefens ansvar for kommuneorganisasjonen skulle være altomfattende og så klar at politikerne kunne kaste rådmannen dersom noe gikk galt (begrepet rådmannsparlamentarisme ble brukt i denne sammenhengen). ${ }^{3}$ Vi ser ikke spor av timeglassmodellen eller andre forsøk på å trekke opp retningslinjer for kontakt mellom valgte politikere og administrativt ansatte i lovens forarbeider. Og vi vet at den etterfølgende saneringen av særlovsbestemmelsene utover på 1990-tallet ga kommunene stor frihet til å organisere både den politiske og den administrative delen av sin virksomhet.

Timeglassmodellen kan imidlertid spores tilbake til det arbeidet KS sin representant i kommunelovutvalget gjorde i etterkant av utvalgets innstilling. ${ }^{4} \mathrm{KS}$ drev da et omfattende informasjonsarbeid, først om innstillingen, senere om betydningen av de endringer som ble vedtatt i den nye loven. Timeglassmodellen ble utviklet som et pedagogisk grep for å kommunisere innholdet i den nye loven i perioden 1990-1991. Endringene i loven var radikale, og det var en viktig oppgave for KS å skape forståelse for de nye rollene som var meislet ut i loven. Timeglassmodellen representerte i den sammenhengen en visuell atskillelse mellom politisk og administrativ side i kommuneorganisasjonen - med politikerne i timeglassets øverste del og administrasjonen i nederste del. Ordføreren og kommunedirektøren ble illustrert med en rund prikk nederst og øverst i timeglasset. Ideen var at disse to burde ha løpende kontakt, og at veien mellom dem burde være kort (også med tanke på kontorplassering).

3 Samtale med Rolf Petter Bjørke 7.6.2019. Vi finner igjen budskapet i timeglassmodellen i «de kommunale tjenestesløyfene» som omtales i et hefte om administrasjonssjefens rolle, som ble laget for det første folkevalgprogrammet etter at den nye kommuneloven trådte i kraft fra 1993 (Kommunenes Sentralforbund, 1995).

$4 \quad$ Samtale med Rolf Petter Bjørke, 7.6.2019. 
Dette fordi de to burde snakke sammen fortløpende og avklare saker og rollefordeling seg imellom, både for å forhindre at ordføreren grep inn i det administrative, og motsatt.

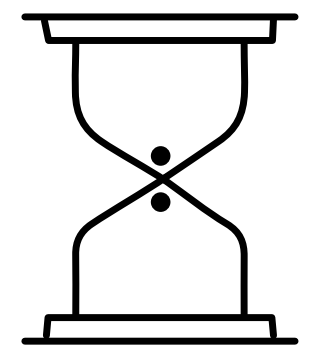

Figur 3.1 Timeglassmodellen som illustrasjon for relasjonen mellom politikk og administrasjon - original utgave. Kilde: samtale med Rolf Petter Bjørke, 7.6.2019.

Ideen var i utgangspunktet at ordfører og kommunedirektør skulle være dørvoktere for kontakten mellom politisk og administrativ sfære. Dette for å understreke og skape forståelse for skillet mellom roller og myndighetsområder. Men dette var utgangspunktet. Tanken var samtidig at administrativ og politisk side, etter hvert som tillit ble etablert, skulle avtale spillereglene for hvordan for eksempel utvalgsledere skulle kontakte etatsansvarlige i administrasjonen. Hensikten var å understreke at det ikke (lenger) var greit at utvalgsledere bestilte utredninger fra - eller kritiserte - etater eller etatsansvarlige direkte. Samtidig var tanken at ordføreren skulle ha omfattende kontakt med utvalgslederne og gruppelederne, at toppledelsen skulle utvikle politikk i fellesskap, og at det var denne toppledelsen ordføreren skulle representere overfor kommunedirektøren.

Timeglassmodellen som idé er vel etablert i norsk kommunal forvaltning. Men i Kommunal Rapports nettutgave 15. oktober 2019 kan vi lese: «Ulovlig å nekte folkevalgte kontakt med ansatte. Ingen kan forby folkevalgte eller borgere å kontakte ansatte i kommuneadministrasjonen. Det sier professor emeritus Jan Fridtjof Bernt». I saken omtales et vedtak om saksbehandlingsreglement i nye Kristiansand kommune, der det het at «[a]ll kontakt mellom politikere og administrasjonen skal gå via kommunedirektøren eller den aktuelle direktør». Saken bekrefter at skillet 
mellom politiske og administrative aktører i kommunen, som altså ble statuert etter endringene i kommuneloven av 2002, lever i beste velgående også i dagens kommunepraksis.

Det er selvsagt variasjon mellom kommuner når det gjelder hvordan timeglassmodellen praktiseres (Lo, 2015). Mens noen kommuner har arbeidet frem spilleregler og åpnet for kommunikasjon mellom politikerne og administrasjonen, har andre holdt på et prinsipielt skille.

\section{En alternativ tilnærming til timeglassmodellen}

Spørsmålet er om et skarpt skille mellom politikerne og administrasjonen fortsatt er formålstjenlig i dagens situasjon, når kommunedirektørens rolle som øverste leder av kommunens administrasjon er vel innarbeidet i norske kommuner. Vi viser dessuten (i kapittel 1) at politisk lederskap ikke bare handler om beslutningsmakt - det handler vel så mye om å vise handlekraft. Det forutsetter politikere som tar initiativ og er involvert $i$ problemformulering og utvikling av løsningsalternativer så vel som i å mobilisere det lokale fellesskapet til handling. Dette er ikke mulig å få til uten omfattende interaksjon mellom ulike aktører - mellom politikerne og administrasjonen så vel som mellom politikerne, berørte og innbyggere generelt. I litteraturen er det, som vi så over, for lengst erkjent at det ikke finnes noe skarpt skille mellom hva som er politikk og hva som er administrasjon, ei heller mellom typer oppgaver politikerne og administrasjonen engasjerer seg i. I en alternativ tilnærming til å skille mellom politikk og administrasjon beskrives relasjonen som en «lilla sone» der den røde politikken blandes med den blå administrasjonen (Alford, Hartley, Yates \& Hughes, 2017).

Som vi har sett, gir både Wilson og Weber, som klassikere innen feltet, gode argumenter for å opprettholde et skille mellom politikk og administrasjon. Måten vi organiserer forholdet mellom sfærene på, bør legge vel til rette for at grunnlaget for politiske beslutninger lever opp til faglige standarder. Samtidig bør de folkevalgte sikre at den politikken som føres, ivaretar de oppgavene som folk oppfatter som viktige, slik at systemet oppnår tilstrekkelig legitimitet. Derfor er det, som kommunedirektør Inge Ryan er inne på i intervjuet som følger, viktig å unngå for mye sand i maskineriet, 
det vil si for mye sand som renner utenfor i timeglassmodellen. Vi vil argumentere for at omfattende kontakt mellom politikere og administrasjon er fullt forenlig med å skille mellom rollene. I stedet for å illustrere forholdet mellom politikk og administrasjon med et timeglass foreslår vi imidlertid å illustrere det kommunalpolitiske systemet som et maskineri der de ulike delene av systemet er gjensidig avhengig av hverandre. I figur 3.2 har vi derfor tegnet det kommunalpolitiske systemet som tannhjul.

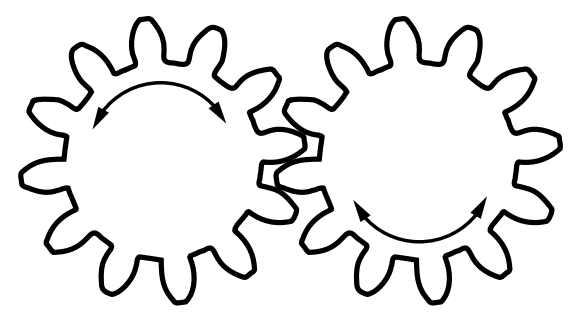

Figur 3.2 Tannhjulmodellen som illustrasjon av det kommunalpolitiske systemet

Etter vår oppfatning illustrerer tannhjulmodellen dagens praksis på en bedre måte enn timeglassmodellen, og den gir grunnlag for fruktbare refleksjoner rundt hvordan forholdet mellom politikerne og administrasjonen bør ordnes og organiseres. Det at tannhjulene - som illustrerer folkevalgte og administrasjon - går inn i hverandre, viser for det første at det eksisterer gjensidig avhengighet mellom flere aktører i det kommunalpolitiske systemet enn mellom ordfører og kommunedirektøren. Det er ikke bare ordføreren, men hele kommunestyret som er avhengig av en velfungerende relasjon til administrasjonen. For det andre assosieres tannhjul i samspill med et fint justert og avstemt system - gitt at systemet fungerer. Tannhjulene - eller aktørene - må følge tett på og tilpasse seg hverandre. Og som kommunalpolitisk system må det jevnlig oljes med en god del tillit. For det tredje går tannhjul rundt og rundt i det kommunalpolitiske systemet, hvilket illustrerer det vedvarende i relasjonen - og kontakten - mellom de folkevalgte og andre aktører. Det er sjelden snakk om ett møtepunkt i en sak, men om flere møtepunkter over tid. For det fjerde illustrerer tannhjulene samtidig at kontaktflatene mellom aktørene er avgrenset - både i bredden og i dybden. Og for det femte er relasjonen mellom tannhjulene meget velordnet. Tannhjulene illustrerer et behov 
for etablering av arenaer, ordninger og rutiner som legger til rette for kontakt mellom politikerne og administrative aktører, men uten at det er kontakt hele tiden og om alle typer saker. Som kommunedirektør Inge Ryan påpeker i intervjuet som følger, er timeglassmodellen i praksis lekk. Slik vil det alltid være.

\section{Forsøk på å endre oppgavefordelingen mellom politikk og administrasjon}

Det å styrke kommunepolitikernes rolle var, som vi har sett, ambisjonen med timeglassmodellen og det kommunale fornyingsarbeidet som fulgte i kjølvannet av kommuneloven av 1992 (se også kapittel 1 for omtale av forskningen knyttet til dette). I forarbeidene til den nye kommuneloven av 2018 (NOU 2016: 4) finner vi ikke noen problematisering av hvordan lokal politikk blir til. Det vises imidlertid til et behov for å styrke det folkevalgte nivået, og til at utvalget ønsker å oppnå en slik styrking gjennom å tydeliggjøre rollen til både de folkevalgte og administrasjonen (NOU 2016: 4, s. 93). Det er likevel et åpent spørsmål hva slags fornyingsarbeid som eventuelt følger når loven nå iverksettes. I det videre skal vi se på noen eksempler på danske og norske kommuner som selv mener at de har iverksatt tiltak for å styrke lokalpolitikernes rolle (redegjørelse for datainnsamlingen følger av vedlegget bakerst i boken). Med utgangspunkt i vår definisjon av politisk lederskap, som forutsetter at politikerne har en sentral rolle også før beslutninger fattes, vil vi være spesielt opptatt av å vise hvordan politikerne på nye måter bringes inn i tidlige faser av politikkutviklingen - hvor politiske saker settes på agendaen i kommunen, problemforståelsen formuleres, og bestemte alternativer utredes.

\section{To forsøk på å styrke politiske organer: Hjartdal og Hedensted}

Hjartdal er en liten norsk kommune med cirka 1600 innbyggere. Kommunestyret består av 17 medlemmer, og fem av disse sitter også i formannskapet. Hedensted er en av de nye kommunene etter kommunereformen $\mathrm{i}$ 
Danmark i 2007, og den har cirka 46 ooo innbyggere. Det er 27 folkevalgte i kommunestyret, hvorav sju sitter i økonomiutvalget. De to kommunene har begge gjort forsøk på å styrke ett av sine sentrale politiske organer gjennom relativt enkle tiltak.

I Hjartdal er dette gjort gjennom et forsøk på å styrke formannskapets rolle i budsjettprosessen. Formannskapet skal etter kommuneloven avgi innstilling til kommunestyret om henholdsvis økonomiplan og årsbudsjett. Den aktuelle nyordningen i Hjartdal besto i å etablere et brukervennlig regneark som gjorde det mulig for formannskapets medlemmer å utarbeide budsjettet på egen hånd. Tradisjonelt har kommunedirektøren i Hjartdal, som i de fleste norske kommuner, foreslått et saldert budsjett. I regnearket som kommunedirektøren introduserte overfor formannskapet, ble de faste utgiftspostene samt den økonomiske rammen lagt inn, og det ble utarbeidet en katalog over mulige tiltak som kommunen kunne prioritere bevilgninger til. Ved hjelp av dette regnearket utarbeidet og forhandlet formannskapspolitikerne om et budsjett som dermed ble et politisk forslag, som de så kunne stemme over. Forsøket varte i to budsjettår, men ble endret fra 2017. I etterkant er regnearket beholdt, men kommunedirektøren avgir nå en innstilling til saldert budsjett slik praksis også var tidligere.

Ideen var at ordningen skulle gi politikerne det verktøyet som var nødvendig for å foreta prioriteringer i budsjettprosessen, og dermed øke politikkens betydning via-à-vis kommunedirektøren. Legger kommunedirektøren frem et eget budsjettforslag, vil det være offentlig og dermed være det som frontes overfor innbyggerne lokalt. Tiltaket ga politikerne kontroll over den tidlige fasen i budsjettprosessen og gjorde dem direkte ansvarlige overfor innbyggerne. I dette lå en mulighet for at de folkevalgte kunne ta regien i budsjettprosessen og dermed sette et sterkere preg på de politiske diskusjonene om lokale utfordringer og alternative løsninger.

I Hedensted er de klassiske kommunestyremøtene supplert med faste dialogmøter der saker til dagsordenen kan meldes inn av alle de folkevalgte (inntil to timer før møtet starter). Møtene avholdes i forkant av de ordinære utvalgsmøtene, men i et lokale med små bord og fri plassering (altså er det ingen partiavhengig plassering slik som i kommunestyret). Møtene er lukket for offentligheten. Det treffes ikke beslutninger 
i dialogmøtene, men oppgaver kan bli oversendt et av de faste utvalgene. De kan også nedsette arbeidsgrupper eller lignende for å utrede saken nærmere. Det er få saker på dagsordenen i hvert dialogmøte, og hver sak som diskuteres, avsluttes med en avtale om hva som er neste steg.

Dialogmøtene legger opp til en mer utforskende, likeverdig diskusjon på tvers av partigrensene. Et sentralt mål med møtene er koordinasjon på tvers av de faste utvalgenes saksområder. I vår sammenheng er imidlertid den muligheten som ligger i å bryte den klassiske dagsordenbundne beslutningsprosessen, like viktig. Her settes dagsordenen opp i et samarbeid mellom kommunedirektør og ordfører eller borgermester. Dialogmøtene gir de folkevalgte mulighet for å utforske problemstillinger og mulige løsninger før de i fellesskap bestemmer hvordan saken følges opp. På den måten definerer og analyserer de folkevalgte lokale problemer og setter selv saker på dagsordenen.

I Hjartdal var det sikker flere grunner til at politikerne ikke ønsket å fortsette med ordningen etter to år. Vi registrerte ikke noen åpenbare negative effekter av ordningen, men flertallet i formannskapet så seg bedre tjent med innledningsvis å ha kommunedirektørens forslag på bordet, som de så kunne spille opp mot i sin behandling av budsjettet. I Hedensted har politikerne en opplevelse av at løsningene de finner frem til, er mer innovative og robuste. Samtidig som de små partiene kommer til orde i større grad, opplever de utfordringer knyttet til sammenhengen mellom dialogmøtenes åpne form og partienes forventninger om å følge partilinjen. Slike møter ville imidlertid ikke kunne lukkes for offentligheten i en norsk kontekst, og det at de er lukket, skaper også utfordringer overfor media i det danske tilfellet. Begge eksemplene viser imidlertid hvordan relativt små tiltak kan medføre relativt store endringer i de folkevalgtes muligheter til å delta mer aktivt i politikkutviklingen.

\section{To forsøk på å tydeliggjøre politisk ledelse: Fredrikstad og Esbjerg}

Med sine om lag 80 ooo innbyggere er Fredrikstad Norges sjuende største kommune. Fredrikstad bystyre består av 53 representanter, hvorav 13 også sitter i formannskapet. Esbjerg befinner seg på Jyllands vestkyst 
og er med sine 115 ooo innbyggere blant Danmarks største kommuner. Esbjergs byråd har 31 medlemmer, og kommunen har et økonomiutvalg bestående av ni representanter. I begge kommuner er det innført institusjonelle endringer med formål om å tydeliggjøre den politiske ledelsen. I Esbjerg er dette gjort gjennom en politisk styringsmodell med «tverrgående økonomiutvalg». Dette innebærer at utvalgslederne for kommunens faste utvalg også sitter i økonomiutvalget (tilsvarende det norske formannskapet). Dette gir økonomiutvalget en særdeles sentral posisjon i kommunen, noe som forsterkes ytterligere ved at både kommunedirektør og fagdirektører deltar på økonomiutvalgets møter. Denne maktkonsentrasjonen balanseres imidlertid gjennom en ordning hvor opposisjonen til enhver tid innehar et gitt antall av utvalgslederpostene (fordelt etter d'Hondts metode).

I Fredrikstad praktiseres en ordning hvor ordfører har innstillingsrett til kommunestyret, og hvor utvalgslederne for de faste utvalgene har innstillingsrett til sine respektive utvalg. Ordningen rokker ikke ved administrasjonens utredningsplikt, ettersom rådmannen fortsatt utreder og gjør sin innstilling i sakene før ordfører eller utvalgsleder legger til sin innstilling. Rådmannens innstilling er fortsatt synlig i saksfremlegget, men det er den politiske innstillingen fra ordfører eller utvalgsledere som gjøres gjeldende frem til behandling i bystyret eller det aktuelle utvalget. I de tilfeller hvor den politiske innstillingen avviker fra rådmennenes administrative vurdering, er det krav om at det gis en begrunnelse for dette fra henholdsvis ordfører eller utvalgsleder. I slike tilfeller vil også saken gå tilbake til rådmannen for en saklig vurdering og kommentar før den behandles i kommunestyret eller det aktuelle utvalget. Ordningen ble innført i forbindelse med et politisk ønske om en mer aktiv politikerrolle, som den gang var knyttet til en debatt om eventuell overgang til parlamentarisk styringsmodell.

En av begrunnelsene for ordningen var at politiske standpunkter ville bli tydeliggjort ved at sentrale politikere i større grad ville måtte ta aktiv stilling i sakene fremfor å «gjemme seg bak» rådmannens administrative innstilling. Våre intervjuer med ledende politikere og administrativt ansatte i kommunen antyder at erfaringene fra ordningen er delte. Det finnes ingen ordning i Fredrikstad som fordeler utvalgspostene 
forholdsmessig (som i Esbjerg), og alle utvalgspostene var fordelt mellom samarbeidspartiene som utgjorde det rådende flertallet i bystyret. Flere opplever at ordningen har medført mindre reell debatt i utvalgene og bystyret, og at den politiske polariseringen i kommunen har økt. Snarere enn at rådmannens innstilling har dannet grunnlag for bredere politiske diskusjoner og påvirkningsmuligheter, har den politiske innstillingsretten forsterket en opplevelse av at samarbeidspartiene har fastlagt sitt standpunkt før reell behandling i utvalgene og kommunestyret. Samtidig påpeker flere at ordningen også har bidratt til å fremheve den politiske rollen til ordføreren og utvalgslederne.

Erfaringene fra Esbjerg er samlet sett mer positive. Både den politiske og administrative ledelsen fremhever den styrkede koordinasjonen gjennom ordningen med tverrgående økonomiutvalg, som også gir mer kontinuitet og ro i de politiske beslutningsprosessene. Mange oppfatter det som positivt at de fleste av sakene avgjøres i utvalgene, og at det dermed blir færre tidkrevende forhandlinger i byrådet. Samtidig er det også i Esbjerg en erfaring at sentraliseringen av makt til et fătall politikere gir begrensninger for bredere politisk debatt. Flere forteller at ordningen medfører en økt avstand mellom de sentrale politikerne i økonomiutvalget og de «menige» politikerne i byrådet, som opplever mindre innflytelse.

Både Fredrikstad og Esbjerg er eksempler på ordninger som styrker de sentrale politikernes muligheter til å komme tidligere inn i de politiske beslutningsprosessene. Sett $\mathrm{i}$ lys av tannhjulmodellen kan begge eksemplene forstås som tiltak for å styrke momentet i de folkevalgtes tannhjul vis-à-vis administrasjonens. Vi ser imidlertid at slike tiltak kan bidra til elitedominans i prosessene og dermed gå på bekostning av bredere involvering av kommunestyrets folkevalgte.

\section{To forsøk på å bringe politikerne aktivt inn i politikkutvikling: Svelvik og Gentofte}

Svelvik er en landbrukskommune i Vestfold med cirka 6600 innbyggere. Kommunestyret har 24 representanter, hvorav sju inngår i formannskapet. Fra 1.1.2020 vil Svelvik inngå i det som blir «nye Drammen kommune» sammen med Drammen og Nedre Eiker. Som ledd i å finne frem til nye 
politiske arbeidsformer har Svelvik eksperimentert med såkalte oppgaveutvalg etter inspirasjon fra Gentofte i Danmark. Gentofte er en betydelig større kommune som befinner seg nord for København, med om lag 75 ooo innbyggere. Gentofte har over flere år eksperimentert og utviklet oppgaveutvalg som en modell for å styrke den politiske lederrollen gjennom å bringe de folkevalgte direkte inn i utviklingen av politikk på ulike områder - i samarbeid med berørte innbyggere og lokale ressurspersoner (se også Sørensen \& Torfing, 2018). Modellen innebærer at det nedsettes ulike midlertidige oppgaveutvalg med ansvar for å utvikle løsninger på avgrensede problemer innenfor ulike politikkområder. I Svelviks tilfelle innebar dette i første omgang at det i 2017 ble nedsatt tre ulike oppgaveutvalg innenfor temaene «velferdsteknologi», «omdømme» og «friluftsliv».

I tråd med modellen fra Gentofte er det i Svelvik kommunestyret som bestemmer tema og gir oppgaveutvalgene sine mandater. Kommunestyret velger også ut fem folkevalgte politikere til hvert av utvalgene. Disse fem velger selv ut en utvalgsleder, og de har også ansvaret for å rekruttere totalt ti innbyggere til det enkelte utvalget. Innbyggerrepresentantene velges på grunnlag av en kompetanseprofil tilpasset det enkelte utvalget, og de rekrutteres primært gjennom annonsering (og i noen tilfeller på direkte forespørsel). Medlemmene i administrasjonen deltar ikke i utvalgene, men har ansvaret for å fasilitere prosessene og bidra med fagpersoner og kompetanse som utvalgsmedlemmene etterspør. Utvalgene bestemmer selv sin arbeidsform, men har en fastsatt frist for å overlevere sluttrapport med utvalgets forslag.

En viktig forskjell mellom den danske modellen fra Gentofte og modellen som praktiseres i Svelvik, er at oppgaveutvalgene i Gentofte leverer sine forslag direkte til kommunestyret for behandling. I Svelvik blir imidlertid forslagene først overlevert formannskapet, som bringer dem videre til rådmannen for ordinær administrativ utredning. Deretter overleveres forslagene i administrativt bearbeidet form til politisk behandling. Forskjellene i praktiseringen av modellen har her bakgrunn i ulike juridiske rammeverk og i det norske prinsippet om kommunedirektørens utredningsplikt (se også Torfing, Sørensen, Winswold \& Røiseland, 2017).

Erfaringene fra oppgaveutvalgsmodellen er generelt positive, både i Gentofte og i Svelvik. I Gentofte fremheves det at modellen bidrar til 
bedre læring rundt problemer og utfordringer, at den bidrar til å skape bedre løsninger, at den stimulerer til nytenkning og innovasjon, og at den bidrar til å bygge mer legitimitet rundt de politiske beslutningsprosessene. I Svelvik, som foreløpig har begrenset erfaring med modellen, er også muligheten til å være mer «hands-on» i politikkutviklingen blitt godt mottatt av både innbyggere og politikere. Det fremheves også at modellen har bidratt til å skape positiv stemning rundt utvikling av politikk, og at den bidrar til å bygge tillitsrelasjoner mellom innbyggerne og kommunen. Samtidig er det også en erfaring at modellen er relativt ressurskrevende, og at særlig den administrative tilretteleggingen kan være krevende. Kommunestyret har dessuten opplevd problemer med å følge opp forslagene fra enkelte av oppgaveutvalgene.

Oppgaveutvalgene er særlig interessante som eksempel på hvordan folkevalgte og innbyggere, som ellers ofte reduseres til roller som henholdsvis beslutningstakere og velgere, sammen kan bringes inn i politikkutviklingen på en måte som, i lys av tannhjulmodellen, øker kontaktflaten - og potensielt tilliten - mellom folkevalgte og innbyggere.

\section{Oppgavefordelingen mellom politikk og administrasjon på agendaen}

Som vi har sett, er det viktig at samspillet mellom politikk og administrasjon hviler på en rollefordeling og noen prinsipper som kan sikre både nødvendig administrativ autonomi og demokratisk kontroll. Administrasjonsparadokset er reelt fordi politikerne er avhengig av administrasjonen for å forstå og fortolke sine omgivelser, for å fange opp saker som bør på dagsordenen, og for å ta stilling til hvilke løsninger som bør utredes. Derfor er det i praksis vanskelig å skille klart mellom politikk og administrasjon. Når oppgavefordelingen mellom politikk og administrasjon settes på agendaen i kommunen, bør diskusjonen derfor handle både om å sikre tilstrekkelig politisk innflytelse og om å sikre tilstrekkelig administrativ autonomi.

Samtidig har vi vist at fordelingen av ansvar og roller mellom politikerne og administrasjonen kan organiseres på svært ulike måter, som 
dermed vektlegger ulike aspekter ved både den politiske og den administrative rollen. Det komplekse samspillet mellom politikk og administrasjon kan ikke reduseres til et sett av rigide regler og universelt anvendbare prinsipper. Vi har argumentert for at timeglassmodellen bør byttes ut med tannhjulmodellen, som åpner opp for betydelig flere arenaer for møter mellom politikere og ulike deler av administrasjonen. Vi mener at denne modellen gir en bedre beskrivelse av situasjonen i dagens kommuner, samtidig som den bedre ivaretar behovet de folkevalgte har for mange kontaktflater i rollen som politiske ledere, hvor de også tar hånd om de tidlige fasene i politikkutviklingen. Det er dessuten viktig å understreke at arbeidsdelingen mellom politikerne og administrasjonen alltid formes av en mer sitasjonstilpasset og prosessuell tilnærming som - for å lykkes - fordrer kontinuerlig dialog og en god dose tillit.

Gjennomgangen av tiltak for å styrke det politiske avtrykket og bringe politikere inn i de innledende fasene av politikkutformingsprosessen viser at relativt små tiltak kan ha relativt stor effekt. Vi har for eksempel vist at det er mulig å etablere ordninger hvor lokalpolitikerne i mindre grad leser administrativt forberedte dokumenter, og i større grad engasjerer seg i utvikling av politikk i samarbeid med innbyggere - dersom politikerne ønsker det. Og vi har vist at det er mulig for politikerne, gjennom bruk av et relativt enkelt regneark, å få økt kontroll over budsjettprioriteringene - dersom politikerne ønsker det. Vi har også sett at organisering av uforpliktende politiske diskusjoner i Danmark, konkretisert som dialogmøter på tvers av en sektororganisert politikk, oppfattes å gi et godt grunnlag for politiske diskusjoner av lokale spørsmål og utforming av dagsorden. Det er i så måte et poeng at dette sistnevnte tiltaket vanskeligere kan realiseres i Norge som følge av offentlighetslovens bestemmelser om åpne møter. Denne typen mindre heldige konsekvenser av åpenhet diskuterer vi mer inngående i kapittel 4 .

Samtidig som det er betydelig rom for eksperimentering og utvikling av nye måter å fordele ansvar mellom politikk og administrasjon på, er det viktig å være klar over at tiltak som berører slike komplekse maktrelasjoner, kan få utilsiktede konsekvenser. Ofte vil et forsøk på å forbedre utvalgte deler av den politiske arbeidsmåten få negative konsekvenser på andre områder. Men også den ordningen som er gjeldende i hver enkelte 
kommune, vil uvegerlig være beheftet med både fordeler og ulemper. Derfor kan det være meget gode grunner til å sette spørsmålstegn ved det som «alltid har vært slik». De folkevalgte mangler ikke handlingsrom selv om kommunedirektøren, som vi har sett, har en spesielt sterk rolle som øverste leder for administrasjonen i norske kommuner. Eksempelvis bestemmer kommunestyret i meget stor grad hvordan den politiske virksomheten skal organiseres. Og eksempelvis er kommunedirektøren gitt det formelle ansvaret for utredning, mens det er kommunestyret som i stor grad bestemmer hvem som skal ha innstillingsrett $\mathrm{i}$ ulike typer saker. Det avgjørende er at kommunens politikere er seg bevisst de mulighetene som faktisk finnes, og at også den rollen de folkevalgte skal spille i det lokalpolitiske systemet, gjøres til gjenstand for utvikling og tilpasning og settes på agendaen med jevne mellomrom.

\section{Referanser}

Aberbach, J. D., Putnam, R. D. \& Rockman, B. A. (1981). Buraucrats \& politicians in western democracies. Cambridge, MA: Harvard University Press.

Alford, J., Hartley, J. Yates, S. \& Hughes, O. (2017). Into the purple zone:

Deconstructing the politics/administration distinction. American Review of Public Administration, 47(7), 752-763.

Berg, R. (200o). Den «gode» politiker. En studie av politiske ledelsesvordier $i$ kommunerne. Odense: Odense Universitetsforlag.

Byrkjeflot, H. (2018). The impact and interpretation of Weber's bureaucratic ideal type in organization theory and public administration. I H. Byrkjeflot \& E. Engelstad (Red.), Bureaucracy and society in transition: Comparative perspectives. Comparative social research (s. 13-35). Bingley, England: Emerald Publishing Limited.

Cuff, R. D. (1978). Wilson and Weber: Bourgeois critics in an organized age. Public Administration Review, 38(3), 240-244. https://doi.org/10.2307/975676

Fivelsdal, E. (1971). Om Max Webers sosiologi. I E. Fivelsdal (Red.), Makt og byråkrati: Essay om politikk og klasse, samfunnsforskning og verdier (s. VII-XXIII). Oslo: Gyldendal Akademisk.

Jacobsen, D. I. (1996). The role of the public manager: Loyalty, autonomy or advocacy? Scandinavian Political Studies, 19(1), 45-65. 
Kleven, T. (1997). Kommunen som lokalpolitisk arena - inn i solnedgangen?

I H. Baldersheim, J. F. Bernt,, T. Kleven \& J. Rattsø (Red.), Kommunalt selvstyre $i$ velferdsstaten (s. 50-90). Oslo: Tano Aschehoug.

Kommunenes Sentralforbund. (1989). Kommunen i 9o-åra. Nye organisasjonsmodeller - nye politiske og administrative roller. Hovedrapport. Oslo: Kommuneforlaget.

Kommunenes Sentralforbund (1995). Administrasjonssjefen si rolle. Opplaring for folkevalgte 1995-1999. Oslo: Kommuneforlaget.

Kommunenes Sentralforbund (2018). Folkevalgt lederskap og kommunal organisering. Hentet 31.5.2019 fra https://www.ks.no/fagomrader/demokrati-ogstyring/for-deg-som-folkevalgt/

Lindblom, C. (1965). The intelligence of democracy. New York: Free Press.

Lidstrøm, A., Baldersheim, H., Corpus, C., Hlynsdottir, E.M., Kettunen, P. \& Klimovsky. D. (2016). Reforming local councils and the role of councillors: A comparative analysis of fifteen European countries. I S. Kuhlmann \& G. Bouckaert (Red.), Local public sector reforms in times of crisis: National trajectories and international comparisons (s. 287-30o). London: Palgrave Macmillan.

Lo, C. (2015). How to win friends and influence policy: An ethnographic study of government and governance in municipal policy development. Doktoravhandling i sosiologi. Bodø: Universitetet i Nordland.

Lo, C. (2018). Normative hierarchy and pragmatic egalitarianism in municipal policy development. I S. Bendixen, M. B. Bringslid \& H. Vike (Red.), Egalitarianism in Scandinavia: Historical and contemporary perspectives (s. 157-178).

Cham, Sveits: Palgrave Macmillan. https://doi.org/10.1007/978-3-319-59791-1

March, J. G. \& Olsen, J. P. (1979). Ambiguity and choice in organizations. Bergen: Universitetsforlaget.

Mikalsen, K. M. \& Bjørnå, H. (2015). Den norske ordføreren: begrenset myndighet, mye makt. I N. Aarsæther \& K. H. Mikalsen (Red.), Lokalpolitisk lederskap $i$ Norden (s. 169-195). Oslo: Gyldendal Akademisk.

Montin, S. (1997). New Public Management på svenska. Politica, 29(3), 262-278.

Mouritzen, P. E. \& Svara, J. H. (2002). Leadership at the apex. Politicians and administrators in Western local governments. Pittsburgh, PA: University of Pittsburgh Press.

NOU 1990: 13 (1990). Forslag til ny lov om kommuner og fylkeskommuner. Hentet fra https://www.regjeringen.no

NOU 2016: 4 (2016). Ny kommunelov. Hentet fra https://www.regjeringen.no

Overeem, P. (2005). The value of the dichotomy: Politics, administration, and the political neutrality of administrators. Administrative Theory \& Praxis, 27(2), 311-329. https://doi.org/10.1080/10841806.2005.11029490 
Peters, B. G. (2009). Still the century of bureaucracy? The roles of public servants. Public Policy and Administration, 2009(30), 7-21.

Røiseland, A. \& Vabo, S. I. (2016). Styring og Samstyring - Governance på norsk (2. utg.) Bergen: Fagbokforlaget.

Sager, F. \& Rosser, C. (2009). Weber, Wilson, and Hegel: Theories of modern bureaucracy. Public Administration Review, 69, 1136-1147. https://doi.org/10.1111/ j.1540-6210.2009.02071.x

Selden, S. C., Brewer, G. A. \& Brundney, J. L. (1999). Reconciling competing values in public administration. Understanding the administrative role concept. Administration \& Society, 31(2), 171-204.

Shore, C. \& Wright, S. (2011). Conceptualising policy: Technologies of governance and the politics of visibility. I C. Shore, S. Wright \& D. Però (Red.), Policy worlds: Anthropology and the analysis of contemporary power (s. 1-25). New York: Berghan Books.

Sørensen, E. \& Torfing, J. (2018). Designing institutional platforms and arenas for interactive political leadership. Public Management Review, 21(10), 1443-1463. https://doi.org/10.108o/14719037.2018.1559342

Svara, J. H. (1998). The politics-administration dichotomy model as aberration. Public Administration Review, 58(1), 51-58.

Svara, J. H. (2006) Introduction: Politicians and administrators in the political process - A review of themes and issues in the literature. International Journal of Public Administration, 29, 953-976.

Svara, J. H. (2014). The myth of the dicotomy: Complementatiry of politics and administration in the past and future public administration. Public Administration Review, 61(2), 176-183.

Steen, P. (2016). Helt Steen, en personlig beretning om et politisk liv. Haugesund: Damocles Forlag.

Torfing, J., Peters, G. B., Pierre, J. \& Sørensen, E. (2012): Interactive governance, advancing the paradigm. Oxford, England: Oxford University Press.

Torfing, J., Sørensen, E., Winsvold, M. \& Røiseland, A. (2017). En ny politisk arbeidsform? Evaluering av oppgaveutvalg i Svelvik kommune våren 2017. Svelvik: Svelvik kommune.

Vabo, S. I. (2000). New oganisational solutions in Norwegian local councils: Leaving a puzzling role for local politicians? Scandinavian Political Studies, 23(4), 343-372.

Vabo, S. I. (2003). Nye politiske styringsmodeller i norske kommuner - hvorfor er ikke særinteressene kommet på «rett spor»? Norsk statsvitenskapelig tidsskrift, 19(2), 119-144.

Vabo, S. I. \& Stigen, I. M. (2000). Kommunal organisering 200o. Redegjørelse for Kommunal- og regionaldepartementets organisasjonsdatabase. NIBR-notat 2000: 128. Oslo: Norsk institutt for by- og regionforskning. 
Weber, M. (1919/1971). Politikk som livskall. I E. Fivelsdal (Red.) og D. Østerberg (Overs.), Makt og byråkrati: Essay om politikk og klasse, samfunnsforskning og verdier (s. 7-45, 95-140). Oslo: Gyldendal Akademisk.

Willumsen, T. (2015). Lederskap på toppen - den norske «timeglassmodellen» $\mathrm{i}$ praksis. I N. Aarsæther \& K. H. Mikalsen (Red.), Lokalpolitisk lederskap i Norden. Oslo: Gyldendal Akademisk.

Wilson, W. (1887). The Study of administration. Political Science Quarterly, 2(2), 197-222

Aarsæther, N. \& Vabo, S. I. (2002). Fristilt og velstyrt? Fokus på kommune-Norge. Oslo: Det Norske Samlaget.

Aarsæther, N., Willumsen, T. \& Buck, M. (2015). Maktforskyvning på toppen? Ordførere og rådmenn i norske kommuner. I N. Aarsæther \& K. H. Mikalsen (Red.), Lokalpolitisk lederskap i Norden. Oslo: Gyldendal Akademisk. 


\section{Om timeglassmodellen \\ - og sanden som renner utenfor}

Tekst: Christian Lo. Intervju foretatt 21. juni 2019.

Det er viktig å holde på den prinsipielle arbeidsfordelingen mellom politikk og administrasjon. Samtidig bør en dynamisk kommuneorganisasjon også ha noen «gråsoner», hvor en mer fleksibel og tillitsbasert samhandling kan finne sted.

Inge Ryan, rådmann i Namsos kommune

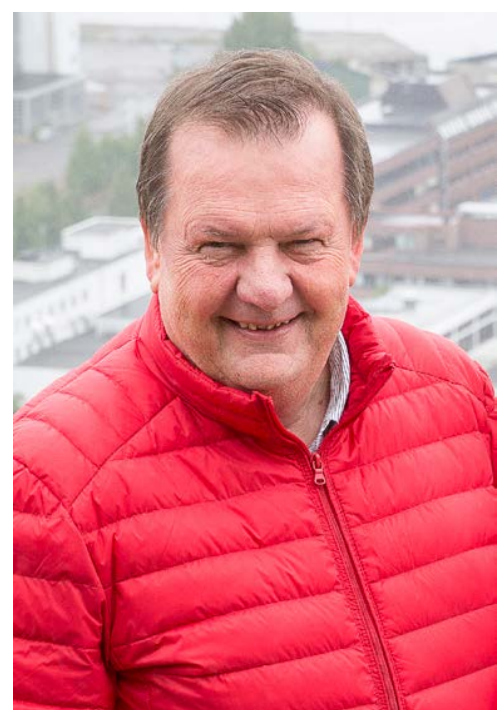

VIRKELIGHETEN: «Altså, administrasjonens jobb er å utrede og iverksette, politikerne bestiller og beslutter. Det er liksom overskriftene. Men så er det jo ikke sånn i virkeligheten», sier rådmann Inge Ryan. (Foto: Ole Morten Melgård, Namsos kommune. Bildet er gjengitt med tillatelse og omfattes ikke av bokens lisens.)

«Det er ingen tvil om at rådmannen [kommunedirektøren] har ansvaret for bedriften», sier rådmann Inge Ryan. «Kommunen er jo en bedrift. Vi i bedrift Namsos er nesten akkurat 2000 ansatte, og jeg er som rådmann 
bedriftsleder for de 2000 ansatte. Jeg opptrer som om det er mitt bord. Ordføreren er ombudsmann for alle innbyggere, alle de 15 ooo innbyggerne som vi har, og det er han som skal ha den direkte dialogen med innbyggere. Jeg har de ansatte, ordføreren har innbyggerne, sånn er liksom det. Så er jo ikke dette så enkelt», forteller Ryan.

Inge Ryan er rådmann for nye Namsos kommune. Ryan har også vært ordfører og varaordfører for Namsskogan kommune. Han har vært fylkespolitiker og har også to perioder på Stortinget, der han fra 2005 til 2009 var parlamentarisk leder for SV. Han var så fylkesmann i Nord-Trøndelag før han begynte i sin nåværende stilling som rådmann. Da vår samtale fant sted, innebar det sistnevnte at Ryan var fungerende rådmann samtidig i tre ulike kommuner som fra 1 . januar 2020 ble til nye Namsos kommune.

Det er få mennesker som har bredere erfaringsgrunnlag for å kunne reflektere rundt våre spørsmål om hva som egentlig er forskjellen mellom det å være politiker og det å være kommunens øverste administrative leder. Et gjennomgående poeng for Ryan er at det prinsipielle skillet er nokså tydelig definert i kommuneloven, men vanskeligere i praksis «[f]ordi jeg har jo også dialog med innbyggere, og ordfører har dialog med ansatte. Men vi er tydelig på rollene. Fordi det er mye debatter, interpellasjoner og spørsmål. Men det jeg har sagt, er at det vi i administrasjonen forholder oss til, er vedtak som er fattet i de ulike politiske organene. Gjerne også vedtak i forbindelse med interpellasjon, men det må være vedtak. Vedtak er viktig fordi det at noe «er sagt» i et kommunestyre eller formannskap, det er det vanskelig å forholde seg til. Derfor er jeg veldig tydelig på at for å få styringslinjen ryddig mellom ordfører og rådmann, så må rådmannen styre etter vedtak, og ordføreren må legge til rette for at det i møtene blir fattet vedtak. Man kan ikke styre etter at noen har sagt noe i et møte. Det er da det blir mange misforståelser og kime til konflikter og usikkerhet».

Ryan utdyper hvordan denne ryddigheten kan praktiseres når vi spør om hans tanker rundt den såkalte timeglassmodellen, altså ideen om at kommunikasjonen mellom den administrative og den politiske delen av organisasjonen skal skje i relasjonen mellom ordfører og rådmann:

«Jeg syns det fungerer i stor grad, men det vil komme noe sand utenfor, altså. Det vil være en del som kontakter rådmannen uten å gå via 
ordføreren. Det tror jeg er uunngåelig, særlig i en liten kommune. Jo mindre en kommune er, jo mer sand er det som forsvinner utenfor det der timeglasset», sier Ryan og fortsetter: «Skillet mellom ordfører og rådmann blir mindre i små kommuner. Men det er ikke nødvendigvis et problem, men det kan bli et problem dersom du ikke informerer. Derfor er informasjon et nøkkelord, og veldig ofte når det blir konflikt mellom ordfører og rådmann, handler det egentlig ikke om villigheten til å gi informasjon, men om mangel på tid til å gi informasjon. Ordføreren reiser mye, og rådmannen er også mye ute, så av og til blir det sånn at det blir mangelfull informasjon, og da kan det fort bli litt krøll.»

"Jeg tror ikke det er noen fare om det kommer noe sand utenfor timeglasset. Men den sanden som har havnet utenfor, må du da bringe tilbake til ordføreren, og vice versa. Det handler litt om det», sier Ryan.

For Ryan er det avgjørende prinsippet at han som rådmann ikke kan handle på en forespørsel av politisk natur, men heller må bringe den over til den politiske arenaen for å få et eventuelt vedtak som administrasjonen da kan handle ut fra. Det viktige blir med andre ord å holde på arbeidsfordelingen mellom politikk og administrasjon, men han understreker også at vellykket samhandling ofte vil kreve en mer fleksibel og tillitsbasert tilnærming. «Prinsippet er at politikerne kommer med bestillingene, vi utreder, politikerne beslutter, vi iverksetter. Altså, administrasjonens jobb er å utrede og iverksette, politikerne bestiller og beslutter. Det er liksom overskriftene. Men så er det jo ikke sånn i virkeligheten.»

Ryan viser til at administrasjonen også spiller en rolle i å gi innspill til politikere og synliggjøre mulighetsrommet for politisk handling. For rådmannen, som vil unngå å legge grunnlag for opprivende politiske konflikter, innebærer dette et behov for en viss forståelse av hva det finnes politisk vilje til å gjennomføre, altså hva som er «politisk mulig».

«For eksempel», forteller Ryan, «så skal vi nå pusse opp et gammelt samfunnshus der vi også har noe administrasjon. Da har vi sendt over et notat som beskriver et mulighetsrom, og vi spør om politikerne ønsker å diskutere dette. Og så har tilbakemeldingene vært at dette synes politikerne er interessant, og at vi kan begynne å jobbe med det. Sant, så vi har noen følere ute. Du klarer det jo ikke dersom det skal være helt sånn rigid på at politikerne bestiller og beslutter, og administrasjonen kun utreder 
og iverksetter. Det er jo en dynamikk her, som du selvsagt må ha, og hvis forholdet er godt mellom ordfører og rådmann, så er denne dynamikken enkel. For da er det jo en gråsone her hvor man snakker og diskuterer sammen, og det er lurt. Jeg mener at i en dynamisk kommune som fungerer godt, der har man disse gråsonene. Ikke bare med ordføreren, men også med andre politikkere. Men det er jo ikke noen arena hvor man beslutter noe. Dette er mer den daglige, uformelle arenaen».

Ryan understeker at slike gråsoner mellom det formelle er en nødvendig del av en dynamisk organisasjon, men han understreker viktigheten av at slike arenaer ikke blir steder hvor beslutninger skjer uavhengig av de formelle prosedyrene. «Da tipper det den andre veien. Du må være forsiktig, slik at det du drøfter av utfordringer på et uformelt møte, ikke blir til at noe er bestemt. Du må holde deg til å si at 'dette er ting vi må se nærmere på’, og så må man da ta det i de rette kanalene», forklarer Ryan.

Igjen handler det om å bringe det uformelle inn i de formelle kanalene. For Ryan er det imidlertid sentralt at administrasjonen behandler alle folkevalgte likt på både de formelle og de uformelle arenaene. Han fremhever også at de formelle arenaene gir politikere gode muligheter til å sette dagsorden. "Jeg mener at hvis du bruker interpellasjoner, og delvis spørsmål, så har du en genuin mulighet til å sette dagsorden. Selvsagt har du også det i budsjettdebattene, og i andre sammenhenger også. Om du som folkevalgt føler at sakslisten er mangelfull, og at du ikke får tatt opp dine saker, så frem med interpellasjoner og spørsmål. Men hvis du i tillegg skal sørge for at det blir iverksatt, sørg for at du har interpellasjoner med et vedtak der du på forhånd har sikret deg at du har flertall. Da blir det noe av det. Men du må gjøre et arbeid på forhånd, sier Ryan.

Selv om utredning er en administrativ oppgave, viser Ryan til at politikere også kan spille en rolle i denne fasen. Dette gjelder særlig i kommuner med en komitémodell, hvor politikeren får en mer aktiv rolle. Men han påpeker at det innenfor en utvalgsmodell heller ikke vil være noe som hindrer at en hovedutvalgsleder eller ordfører blir trukket inn for å diskutere hva som må inn i en utredning, særlig hvis saken har en viss kompleksitet. Dette medfører imidlertid også et dilemma, ettersom det da er særlig disse rollene som får innvirkning på bekostning av det øvrige kommunestyret. Ryan forklarer: 
«Det er ingen tvil om at de store partiene kommer tettere på, fordi de har flere ressurser, og de store partiene har som regel lederne. Det er derfor jeg sier at det er så viktig at de små partiene benytter seg av de instrumentene med spørsmål og interpellasjoner, som jeg mener er kjempeviktige. Det handler om å få litt politisk liv og røre, sørge for at det ikke blir ... altså, vi må ikke ha for mye av det at rådmannens forslag blir enstemmig vedtatt. Vi må på en måte ha noen som drar opp vyene, perspektivene og ideene. Husk på at det ligger en egenverdi i politisk debatt.» 


\title{
Åpenhetsparadokset Åpne eller lukkede møter $\mathrm{i}$ lokalpolitikken?
}

\author{
Espen Leirset
}

Nord universitet

\section{Asbjørn Røiseland}

Nord universitet, OsloMet - storbyuniversitetet

\begin{abstract}
This chapter focusses on the publicity of political meetings. While Norway has mandatory open meetings in all political bodies at the municipal level, in Denmark all the meetings apart from the council meetings are mandatory closed. This gives a good opportunity to study how the difference plays out in practice, and which effect open meetings have for political leadership. The analysis illustrates the paradox related to openness - open meetings do not necessarily give more openness. Instead, more deliberation and political discussions in Norway are moved to informal meetings external to the formal democratic system, like political party meetings which are closed to the public. In a brief and subsequent chapter, two Norwegian Mayors explain their experiences with closed meetings.
\end{abstract}

Keywords: open meetings, transparency paradox, deliberation, local policy, democratic control, accountability

\section{Introduksjon}

I dette kapitlet diskuteres det vi har kalt et «åpenhetsparadoks», som henspiller på en motsetning mellom regler om åpenhet på den ene siden og de faktiske konsekvensene av disse reglene på den andre siden. Bakgrunnen er at Norge har et formelt krav om møteoffentlighet $\mathrm{i}$ alle kommunale

Sitering av denne artikkelen: Leirset, E. \& Røiseland, A. (2020). Åpenhetsparadokset. Åpne eller lukkede møter i lokalpolitikken?. I A. Røiseland \& S. I. Vabo (Red.), Folkevalgt og politisk leder (Kap. 4, s. 95-119). Oslo: Cappelen Damm Akademisk. https://doi.org/10.23865/noasp.8o.ch4

Lisens: CC BY-ND 4.0. 
politiske organer. Her skiller Norge seg ut i Norden. I Danmark er for eksempel alle møtene utenom kommunestyret lukket, og danske politikere har ikke engang lov til å referere hva andre har sagt i møtet (Sletnes, Henrichsen, Lundin \& Mäkinen, 2013, s. 711ff). Vi har undersøkt hva denne forskjellen betyr, og hvordan de norske reglene for møteoffentlighet virker i praksis.

Med jevne mellomrom dukker det opp saker i norske medier som gjelder prinsipper for møteoffentlighet. I 2018 var det debatt om åpenhetskulturen i Skien og Porsgrunn kommuner, der gruppelederne i partiene møttes uformelt for å diskutere fritt rundt store lokale saker. Etter at lokalpressen klagde på praksisen, fikk de medhold fra Fylkesmannen om at møtepraksisen var ulovlig (Aukrust, 2018a, 2018b). Ordfører i Porsgrunn, Robin Kåss (Ap), mener tolkningen er streng, og at kommunene blir strengere behandlet enn sentrale myndigheter. Likevel vil han ikke ta opp kampen for å få endret loven og lukke møtene: «Problemet med å fronte en slik sak er at det gir inntrykk av mindre åpenhet» (Aukrust, 2018a). For en folkevalgt oppfattes det altså fort som illegitimt å argumentere for lukkede prosesser.

I den teoretiske litteraturen om demokrati blir borgernes rett til informasjon om myndighetens beslutninger og handlinger sett på som fundamental og sentral (Heald, 2006). Det finnes mange eksempler på at åpenhet har bidratt til positive utfall og avsløring av maktmisbruk. Et norsk eksempel er vannverkskandalen på Romerike, mens et eksempel fra internasjonal politikk er avsløringer i regi av nettstedet WikiLeaks (Gedde-Dahl, Hafstad \& Magnussen, 2008; Restad, 2018; Sirevåg, 2019). I utgangspunktet er det vanskelig å se at åpenhet og informasjonsdeling kan ha noen negative konsekvenser for styring og samfunn. Samtidig er historien full av eksempler på offentlig styring der hemmelighold og informasjonsgjerrighet fremstår som avgjørende for et positivt utfall (Torfing, Peters, Pierre \& Sørensen, 2012, s. 208). Et norsk eksempel er ordinære, lukkede komitémøter i det norske Stortinget, og et internasjonalt eksempel er de alliertes skjulte forberedelser til D-dagen i 1944. På prinsipielt grunnlag er det dermed god grunn til å diskutere nærmere under hvilke forutsetninger full åpenhet er et gode, og når det ikke er det (Allison, 1999; Fung, Graham \& Weil, 2007). 
Regler for møteoffentlighet er et uttrykk for én viktig side ved åpenhet. De norske prinsippene for kommunal møteoffentlighet ble nedfelt $\mathrm{i}$ kommuneloven av 1992 (NOU 1990: 13). De ble så spesifisert av Regjeringen i 2010, og videreført i ny kommunelov i 2018 (NOU 2016: 4). Hensikten med innføringen av prinsippet i norsk lov var å sikre allmennhetens innsyn og på den måten styrke åpenhet og demokrati. Dette betyr at norske kommunepolitikere har få eller ingen tverrpolitiske arenaer der de kan diskutere saker i fortrolighet, uten medias tilstedeværelse. Det finnes riktignok unntak fra reglene om møteoffentlighet, men dette gjelder kun avgrensede spørsmål som er knyttet til lovbestemt taushetsplikt, personvern, arbeidstakerforhold eller tungtveiende offentlige interesser. Dette er relevant med tanke på politisk lederskap fordi denne typen lederskap dreier seg om å forstå problemer, om å foreslå og beslutte løsninger og mobilisere handlekraft (Tucker, 1995). Hvilke møtearenaer politikere har for å diskutere sammen, og hvilke rammer disse møtene har, er derfor viktige rammebetingelser for politikernes mulighet til å utøve politisk lederskap. Dette gjelder ikke minst med tanke på den muligheten politikerne har til å ta initiativ, sette agenda og utforme politikk, slik det er beskrevet i første kapittel i denne boken.

I dette kapitlet skal vi først diskutere og behandle åpne versus lukkede møter som en verdikonflikt som det ikke finnes noen opplagt løsning på. Men vi skal også argumentere for at det oppstår et paradoks som følge av de norske reglene for møteoffentlighet. Paradokset består i at de reelle diskusjonene har en tendens til å bli flyttet ut av det formelle systemet og inn i fora som ikke reguleres gjennom kommuneloven, som for eksempel partigrupper, partimøter eller uformelle og til dels hemmelige sammenkomster blant politikere. Empiriske eksempler som presenteres i kapitlet, antyder at nettopp dette er tilfellet i Norge, og at vi i praksis har en mindre åpen kommunesektor enn det lovgiverne har sett for seg.

Analysen i kapitlet bygger på en sammenlikning mellom norske og danske kommunepolitikere som virker innenfor ganske ulike regler og tradisjoner for møteoffentlighet. Vi vil være spesielt opptatt av hvilke formelle og uformelle arenaer valgte politikere i Norge og Danmark opplever at de har for diskusjoner av problemer og politiske løsninger, og hvilke konsekvenser dette har for politikkutforming og demokrati. 


\section{Åpenhet versus lukkethet - en verdikonflikt}

Hvor åpne skal politiske prosesser være? Spørsmålet berører en verdikonflikt (Jørgensen \& Bozeman, 2007) hvor vi på den ene siden må ivareta borgernes rett til innsyn i og kontroll over hva offentlige myndigheter foretar seg, mens vi har politikernes legitime behov for å diskutere saker i fortrolighet på den andre. Denne verdikonflikten er nært knyttet til spørsmålet om hva som dypest sett er politikernes rolle i en kommune. Er politikerne, for å ty til en metafor, «kapteinen som styrer skuta», eller befinner de seg snarere i maskinrommet der de sammen med administrasjonen bidrar til problemløsing? Et annet spørsmål er om politikerne står utenfor eller innenfor kommunen som organisasjon (Jørgensen \& Bozeman, 2007, s. 366; Schmidt, 2008).

Åpenhet i politiske prosesser har minst to sentrale begrunnelser. For det første forutsetter det representative demokratiet at velgerne kan velge fritt mellom ulike alternativer. Men for at slike valg skal være rasjonelle, trengs så mye informasjon som mulig, noe åpenhet kan bidra til (Stiglitz, 2008). Åpenhet om politiske avveininger og vurderinger gjør at velgeren kan ta mer informerte valg på valgdagen. I et slikt perspektiv bidrar åpne møter til at markedsplassen (valgdagen) for politiske løsninger, kandidater og partier fungerer bedre fordi velgerne får tilgang til mer informasjon.

For det andre skal åpenhet bidra til styrket legitimitet. Demokratisk kontroll skal forhindre korrupsjon og maktmisbruk ved at de politisk valgte lederne oppfører seg bedre, slik Bentham (2001, s. 277) formulerte det: «Jo mer vi blir sett, desto bedre oppfører vi oss.» Åpenhet er med andre ord en demokratisk kjerneverdi og et sentralt virkemiddel i kampen mot korrupsjon og vanstyre.

Samtidig er det få som vil protestere på at enkelte politiske prosesser iblant må være lukket. Utenrikspolitikken, forsvarspolitikken og sikkerhetspolitikken er åpenbare eksempler. Også i lokalpolitikken finnes det saker og spørsmål som ikke kan være åpne, for eksempel i forbindelse med anbudsprosesser eller i saker som berører enkeltpersoner på en inngripende måte. Slike saker er omfattet av egne regler i kommunelovgivningen. 
Utviklingen i retning av at offentlig politikk blir mer innvevd i marked og sivilsamfunn (det som gjerne omtales som interaktiv styring eller samstyring), har også konsekvenser for spørsmålet om åpenhet. Stor grad av åpenhet kan gjøre slike styringsformer mer krevende, eksempelvis når offentlige myndigheter involveres i kvasimarkeder, partnerskap og andre styringsnettverk (Torfing \& Peters et al., 2012, s. 208). Flere forskere argumenterer derfor med at vi bør skille mellom åpenhet i prosess og åpenhet i resultat, og at et godt resultat noen ganger kan forutsette en mer lukket prosess (Mansbridge, 2009; Torfing et al., 2012).

Det fremste argumentet for lukkede møter er hensynet til deliberasjon (Habermas, 1995: Elster, 1998; Heald, 2006). Deliberasjon betegner en fri, kritisk og konstruktiv samtaleprosess der vi utforsker egne og andres argumenter. Aktørene er åpne for å endre oppfatning og lytte til hverandres argumenter. Formålet er å komme frem til så gode løsninger som mulig, ved at alle sider og ulike motforestillinger kan drøftes og vurderes. Slik deliberasjon forutsetter tillit mellom partene, slik at de kan føle seg trygge på at fri drodling ikke vil brukes mot dem på et senere tidspunkt. Vi kan kalle slike deliberasjonsmøter for politiske arbeidsmøter. Politiske debatter, der aktørene er mest opptatt av å få frem politiske skillelinjer og markere egen politikk, representerer den rake motsetningen til politiske arbeidsmøter. Slike debatter kjenner vi fra paneldebatter før valg, fjernsynsdebatter og kommunestyremøter og møter i Stortingets plenum, der de folkevalgte med retoriske virkemidler skal overbevise forsamlingen om sin politikks fortreffelighet, og om hvor galt det går når og hvis andre får styre. Vi kan kalle slike møter for politiske symbolmøter. Og vi vil ta utgangspunkt $\mathrm{i}$ at graden av åpenhet utgjør en viktig forskjell mellom arbeidsmøter og symbolmøter. Å markere eget parti med viktige symboler er ikke så meningsfullt dersom møtet er lukket. Og dersom møtet er åpent, er det ikke så lett å arbeide seg gradvis frem til gode, felles beslutninger (Leirset, 2019).

Motstridende og tilsynelatende uforenlige hensyn gjør spørsmålet om møteoffentlighet til en verdikonflikt og dermed til et dilemma som ethvert kommunesystem må ta stilling til. I tabellen nedenfor har vi systematisert noen argumenter for og imot en ordning med åpne møter versus lukkede møter. 
Tabell 4.1 Argumenter for og imot åpne og lukkede møter

\begin{tabular}{|c|c|c|}
\hline & Åpne møter & Lukkede møter \\
\hline Fordel & $\begin{array}{l}\text { - velgerkontroll } \\
\text { - } \text { bred informasjon ut til } \\
\text { offentligheten } \\
\text { - synliggjøring av politiske } \\
\text { skillelinjer } \\
\text { - disiplinering av politikere }\end{array}$ & $\begin{array}{l}\text { - mer løsningsorient og fri debatt } \\
\text { - lettere å finne kompromisser } \\
\text { - mer effektiv bruk av } \\
\text { politikernes kompetanser }\end{array}$ \\
\hline Ulempe & $\begin{array}{l}\text { - rituelle møter der utfall er } \\
\text { forhåndsbestemt } \\
\text { - snever debatt }\end{array}$ & $\begin{array}{l}\text { - lite synlighet overfor velgerne } \\
\text { - vanskeligere å drive } \\
\text { opposisjonspolitikk }\end{array}$ \\
\hline $\begin{array}{l}\text { Risiko for } \\
\text { legitimitetstap }\end{array}$ & $\begin{array}{l}\text { - politikk blir rituell, symbolsk og } \\
\text { overflatisk }\end{array}$ & $\begin{array}{l}\text { - borgerne mistenker kameraderi, } \\
\text { mislighold og utvikling av } \\
\text { styringseliter }\end{array}$ \\
\hline $\begin{array}{l}\text { Mulig } \\
\text { kompensasjonstiltak }\end{array}$ & $\begin{array}{l}\text { - politikerne gjennomfører } \\
\text { fordomsfrie og deliberative } \\
\text { diskusjoner andre steder }\end{array}$ & $\begin{array}{l}\text { - politikerne deltar jevnlig i åpne } \\
\text { politiske debattmøter } \\
\text { - forklare prosessen underveis }\end{array}$ \\
\hline
\end{tabular}

Mens åpne møter legger til rette for velgerkontroll og synliggjøring av politiske skillelinjer, gir lukkede møter anledning til mer problemorienterte og åpne debatter der politikerne kan finne frem til kompromisser basert på den samlede kompetansen i en politisk forsamling. Ulempene med lukkede møter blir de motsatte av fordelene med åpne møter; det blir mindre synlighet overfor velgerne og vanskeligere å markere seg som opposisjonspolitiker. En ulempe ved åpenhet er tilsvarende at møtene får en rituell karakter, der utfallet er gitt, og der debatten først og fremst handler om å synliggjøre uenighet.

Både åpne og lukkede møter innebærer risiko for tap av legitimitet, men på ulike måter. Ved åpne møter risikerer man å miste legitimitet som følge av at politikken blir mer rituell, symbolsk og overflatisk, og ved at den ikke handler om det som er viktig for folk flest. Risikoen ved lukkede møter ligger først og fremst $\mathrm{i}$ at borgerne kan mistenke - med mer eller mindre god grunn - at politikerne er en elite som er mest opptatt av seg selv og sine posisjoner. Teoretisk sett vil det være mulig å kompensere for ulemper og risiko med avbøtende tiltak. I et system med lukkede møter kan ulempene reduseres gjennom hyppigere debattmøter der politikerne møter borgerne og offentligheten. I et system med åpne møter kan ulempene reduseres ved å gjennomføre frie og deliberative diskusjoner på andre arenaer, for eksempel i lukkede felles partimøter eller i uformell 
dialog mellom enkeltpolitikere. Som vi kommer tilbake til nedenfor, legger imidlertid norsk lovgivning begrensninger på denne muligheten.

Alle demokratiske systemer må på en eller annen måte forholde seg til dilemmaet mellom åpne symbolmøter og lukkede arbeidsmøter. Som vi skal se nedenfor, er den praktiske tilnærmingen til dilemmaet ganske forskjellig i Norge og Danmark, som er to land som vi regner som relativt like når det kommer til offentlig forvaltning, kommunesystem og styringstradisjon (jf. Kapittel 1).

\section{Møteoffentlighet i Norge - og i Danmark}

I Norge ble radikale regler for møteoffentlighet innført med kommuneloven av 1992. Vi omtaler her prinsippet som radikalt, fordi møtene $\mathrm{i}$ politiske nemnder og formannskap var lukket før lovens iverksettelse fra 1993, og kun kommunestyrets møter var åpne. Dagens regler for kommunene kan ses på som radikale i forhold til Stortingets arbeidsprosesser, der møtene i stortingskomiteene er lukket. I forarbeidene til den nye kommuneloven la kommunelovutvalget «stor vekt på den mulighet for demokratisk kontroll som åpne møter representerer» (NOU 1990: 13, s. 309). I tillegg uttrykte utvalget håp om at åpenheten skulle bidra til at folk fikk større innsikt i kommunal forvaltning, og at avstanden mellom velgere og folkevalgte ble redusert. Forarbeidene til loven tok også opp problemer med åpne møter, for eksempel at det ville bli vanskeligere å «sikre en mest mulig fri og uavhengig meningsutveksling blant organets medlemmer» (NOU 1990: 13, s. 309), og at det var en risiko for «at den videre beslutningsprosess blir bundet opp av politisk prestisje» (NOU 1990: 13, s. 309). Utvalget beskrev imidlertid ikke løsninger på disse problemene, og muligheter for å håndtere disse problemene ble heller ikke tatt inn i lovteksten.

Møteoffentlighetsprinsippet drøftes mer inngående i forarbeidene til den nye kommuneloven som ble vedtatt i 2018 (NOU 2016: 4, s. 176). Her opprettholdes anbefalingen om at alle politiske utvalg i kommune-Norge skal være offentlige. Det var imidlertid dissens i utvalget. Et mindretall ønsket å la politikerne ha mulighet til å få innsikt i en sak og foreta noen diskusjoner før den ble offentlig. Utvalget ble imidlertid ikke enig i dette 
prinsipielle spørsmålet, og rapporten beskriver at et mindretall på seks tapte voteringen mot sju stemmer. Som følge av at det tidvis etter 1993 har vært uklart om felles gruppeledermøter er lovpålagt å være åpne, tar flertallet i utvalget til orde for at «møter hvor for eksempel alle gruppelederne for partiene i kommunestyret møtes for å behandle konkrete saker, vil [...] etter utvalgets forslag [også i ny kommunelov] måtte følge reglene om møteoffentlighet» (NOU 2016: 4, S. 178). I behandlingen av forslaget til ny kommunelov fulgte Stortinget flertallsinnstillingen vedrørende møteoffentlighet. De nåværende norske bestemmelsene innebærer dermed at politiske møter i Norge på generell basis er åpne. Siden bestemmelsen er så vidtgående, er det få muligheter for å kompensere for de negative sidene ved åpne møter.

I Danmark har man valgt en kombinasjon av åpne og lukkede møter, avhengig av type beslutningsarena. Mens det øverste organet, tilsvarende det norske kommunestyret, alltid er åpent (med unntak for spesielle enkeltsaker), er møter i underliggende utvalg og komiteer alltid lukket.

Generelt har hensynet til demokratisk kontroll vært mindre vektlagt i Danmark, og hensynet til å bygge politisk konsensus er blitt betont desto sterkere. I forarbeidene til den danske kommuneloven poengteres ulempene ved åpne møter (Indenrigsministeriet, 1977, s. 46): Åpne møter kan for det første føre til at den «reelle form for debat bliver henlagt til et annet sted». For det andre kan åpne møter gi risiko for «sterk politisering» av arbeidet i utvalgene. For det tredje kan administrasjonen bli mer «tilbageholdende med at forelægge materiale for udvalgene på det tidligst mulige stadium». Hensynet til de små partigruppene vektlegges også som et selvstendig poeng i argumentasjonen for lukkede møter.

Den danske loven fungerer slik at møtekalenderen og saklisten er offentlig. På den måten kan journalister og andre interesserte få innsyn i aktuelle saker og belyse disse ved ordinært intervju- og reportasjearbeid. Selve møtene i de politiske utvalgene og i økonomiutvalget (tilsvarende formannskapet) er imidlertid lukket. Det er også en form for referatforbud fra disse møtene, slik at det er ulovlig for en politiker å referere hva en annen politiker har sagt i møtet, til offentligheten. Dette referatforbudet gjelder ikke overfor egen partigruppe. De kan altså referere diskusjoner fra utvalgsmøtene inn i sitt eget partimøte. Hensikten med 
referatforbudet er at alle politikerne skal kunne diskutere fritt i møtet, uten frykt for at deres høyttenking blir referert i offentligheten i den tidlige fasen i politikkutformingen. De skal kunne gjøre politiske sonderinger som ikke er ferdig gjennomtenkt, og de skal kunne skape et «politisk verksted» i utvalget. Når en gruppe mennesker blir satt til å arbeide sammen i et slikt kollektiv, med den klare rammen at de ikke snakker om hva andre har sagt, utenfor møterommet, er det rimelig å forvente at dette bidrar til en indre lojalitet i gruppen (Leirset, 2019). Dette er trolig med på å bygge en sterkere konsensuskultur.

I den følgende analysen utforsker vi hva denne beskrevne forskjellen i regelverk betyr i praksis for politisk lederskap og politikkutvikling i norske og danske kommuner. Politisk lederskap er, som vi har argumentert for i kapittel 1, en bred funksjon som ikke bare handler om å fatte beslutninger, men også om å forstå og definere aktuelle problemer og diskutere ulike løsninger. Vi er spesielt opptatt av hvor i det politiske systemet politikerne finner rom for dette. Hypotesen - basert på diskusjonen så langt - er at danske kommunale utvalg med sine lukkede møter representerer en arena for brede diskusjoner om problemer og løsninger, mens norske kommunepolitikere gjennomfører slike diskusjoner andre steder enn i de formelle folkevalgte organene.

\section{Kort om data og metode}

De empiriske eksemplene nedenfor er hentet fra dybdeintervjuer av et utvalg lokalpolitikere i to danske og to norske kommuner. De fire kommunene har mange likhetstrekk. Alle styres gjennom en kollegial politisk styringsmodell, i Norge kjent som formannskapsmodellen. De har ikke gjennomført tunge reformer de siste årene, og de er på mange måter tradisjonelle kommuner som ikke skiller seg nevneverdig fra gjennomsnittlige kommuner i sine land. Det må likevel nevnes at kommunene er noe ulike med hensyn til befolkningsstørrelse, noe som følger logisk siden danske kommuner gjennomgående er større enn norske. Men kommunene er like med tanke på at de ligger utenfor de større byene, og de er store nok til at det finnes lokale medier som har interesse av å dekke kommunalpolitiske møter og saker. 
Det empiriske designet for undersøkelsen bygger på ideen om at vi velger rimelig like kommuner med én kritisk forskjell og studerer betydningen av denne forskjellen. Den kritiske forskjellen som studeres her, er ulike formelle regler for møteoffentlighet i Norge og Danmark. Gitt at det er en forskjell mellom landene når det gjelder den praksisen vi finner, antar vi at denne skyldes ulikhet i reglene om møteoffentlighet. Vi antar også at eventuelle likheter mellom de norske kommunene og mellom de danske kommunene styrker antakelsen vår om at det er den forventede forskjellen mellom de to landene som følger av de formelle reglene for møteoffentlighet. Dette designet tilsvarer det som i metodelitteraturen omtales som «likhetsmetoden» (Przeworski, 1987).

Tabell 4.2 Empirisk caseoversikt

\begin{tabular}{|c|c|c|c|c|}
\hline & Norge - nord & Norge - sør & Danmark - øst & $\begin{array}{r}\text { Danmark - } \\
\text { vest }\end{array}$ \\
\hline Folketall & ca. 20000 & ca. 16000 & ca. 30000 & ca. 50000 \\
\hline Styreform & Formannskap & Formannskap & Formannskap & Formannskap \\
\hline $\begin{array}{l}\text { Lokalpresse som } \\
\text { dekker lokalpolitikken? }\end{array}$ & Ja & $\mathrm{Ja}$ & $\mathrm{Ja}$ & $\mathrm{Ja}$ \\
\hline Politisk situasjon & $\begin{array}{r}\text { Konsensus- } \\
\text { preget, hvor } \\
\text { et stort flertall } \\
\text { av partier } \\
\text { samarbeider i } \\
\text { «posisjon» }\end{array}$ & $\begin{array}{r}\text { Marginalt } \\
\text { flertall for en } \\
\text { partigruppe } \\
\text { som har } \\
\text { «posisjon», } \\
\text { konfliktpreget }\end{array}$ & $\begin{array}{r}\text { Konsensus- } \\
\text { preget }\end{array}$ & $\begin{array}{r}\text { Konsensus- } \\
\text { preget, med } \\
\text { partigruppe } \\
\text { som har } \\
\text { «posisjon» }\end{array}$ \\
\hline $\begin{array}{l}\text { Erklært politisk } \\
\text { «posisjon» } \\
\text { med skriftlig } \\
\text { samarbeidsavtale }\end{array}$ & $\begin{array}{r}\text { Ja, stort } \\
\text { flertall }\end{array}$ & $\begin{array}{r}\text { Ja, knapt } \\
\text { flertall }\end{array}$ & $\begin{array}{r}\text { Ja, klart } \\
\text { flertall }\end{array}$ & $\begin{array}{r}\text { Ja, knapt } \\
\text { flertall }\end{array}$ \\
\hline Antall informanter & 8 & 10 & 11 & 11 \\
\hline
\end{tabular}

Som det fremgår av tabell 4.2, ble det gjennomført intervjuer med totalt 40 informanter, flesteparten lokalpolitikere. I presentasjonen er både kommunenavn og informanter anonymisert, noe som var et premiss ved datainnsamlingen. Det er lagt vekt på å intervjue politikere fra så mange partier som mulig, med lang erfaring og god oversikt over lokalpolitikken. I tillegg har vi inkludert et fåtall politikere med kortere politisk bakgrunn i alle casekommunene. De fleste intervjuene er gjort som individuelle dybdeintervjuer, men det er også gjennomført et fokusgruppeintervju i 
hver kommune med to til fire informanter. Blant informantene inngår også et lite utvalg personer som ikke er del av lokalpolitikken, men som kjenner de lokalpolitiske forholdene godt. Dette gjelder en til to personer fra den kommunale administrasjonen og en til to representanter for lokalpressen i hver casekommune. I tillegg har vi observert minst ett politisk møte i hver kommune. I sum har denne metodiske tilnærmingen gitt et rikt tilfang av informasjon som er egnet til å besvare våre hovedspørsmål, det vil si hvilke formelle og uformelle arenaer valgte politikere i Norge og Danmark opplever at de har til disposisjon for brede diskusjoner om problemer og løsninger, og hvilke konsekvenser dette har for politikkutforming og demokrati.

\section{Hvor har politikerne sine «politiske arbeidsmøter»?}

Norge og Danmark har valgt ulike tilnærminger til møteoffentlighet. I våre intervjuer har vi spurt hva som er de viktigste møtene i den politiske prosessen, altså hvor lokalpolitikerne mener at de kan diskutere mest fritt og konstruktivt rundt aktuelle politiske saker. I begge land er det vanlig å møtes i egne partigruppemøter underveis i den politiske prosessen. Omfanget av disse møtene er imidlertid større i de to norske kommunene enn i de to danske, og informantene beskriver dem som mer betydningsfulle i de norske enn i danske. I Norge ser det ut til at representantene i større grad etablerer oppfatninger om en sak i det lukkede gruppemøtet. Det synes å være høy terskel for å endre oppfatning når det åpne, formelle møtet starter.

Når vi har gruppemøte, så blir vi enige. Internt. Så er det en som legger fram det i [det formelle] møtet. Det er sjelden at vi skifter mening underveis $i$ [det formelle] møtet. (Norsk posisjonspolitiker)

Denne politikeren, som oppfatter seg som «posisjonspolitiker», beskriver at sakene diskuteres i gruppemøtet, og at partiet da gjør sin egentlige beslutning der. Informanten synes det er vanskelig å se for seg at de ikke 
skal ha et uformelt møte på forhånd, der de kan diskutere åpent og fritt. Det beskrives som vanskelig med åpne diskusjoner i de formelle møtene.

Det ville vært vanskelig for oss internt i partiet å være uenige dersom vi måtte ta diskusjonen i det åpne møtet. Det er lettere for oss å få den diskusjonen når vi sitter for oss selv. (Norsk posisjonspolitiker)

Uttalelsen ovenfor beskriver det åpne møtet som en slags scene, og gruppemøtet som et bakrom. Det er ikke tilfeldig hvor uenighet innad i partigruppene tas opp, og det er et sentralt poeng at dette gjøres i det uformelle, lukkede gruppemøtet. Da slipper de å vise frem uenighet utad. I det formelle, åpne møtet gjelder det imidlertid å stå sammen. Det samme inntrykket gir representanter for partier som ikke er en del av flertallsgruppen.

Veldig mye av politikken er avgjort i gruppemøtene på forhånd, der vi ikke deltar. Selv om det kan ligge løsninger utenfor det de har diskutert, holder de seg fast til det de har blitt enig om på forhånd. (Norsk opposisjonspolitiker)

Denne informanten mener den viktigste politikkutformingen skjer i de uformelle formøtene, ikke i utvalgsmøtene. Dette underbygges av en kollega i opposisjonen, som sier at posisjonspartiene som regel er enige når de har møte i utvalget. Dette skyldes at de har hatt et møte på forhånd og har avtalt hva de skal mene. Dermed spiller det liten rolle hvilke argumenter de fremfører i utvalgsmøtet:

Det er nesten slik at de [posisjonen] ikke gidder å ta ordet til det du har sagt engang. De stemmer det bare ned. (Norsk opposisjonspolitiker)

Disse to politikerne, som forstår seg selv som «opposisjonspolitikerne», beskriver at det å bruke argumenter for å overbevise posisjonen er nytteløst fordi posisjonsgruppen har bundet seg opp til det de har bestemt seg for på forhånd. Den eneste måten å nå frem på er ved å fremme alternative forslag som det voteres over. Forslagene blir som regel nedstemt, men de får i det minste markert politisk uenighet. 
Blant danske kommunepolitikere omtales både partigruppemøtene og de formelle møtene (altså de lukkede møtene) som gode diskusjonsarenaer. I Danmark er det de formelle utvalgsmøtene (altså der flere partier sitter samlet) som beskrives som de beste. De som sitter i økonomiutvalget (tilsvarende det norske formannskapet), mener at dette er den fremste arenaen for brede politiske diskusjoner. De andre politikerne peker først og fremst på utvalgsmøtene. Disse møtene er sektororientert og faglig spisse, noe som tilrettelegger for at deltakerne er godt informert, noe som igjen gjør diskusjonen god.

Utvalgsmøtene gir god mulighet til å finne løsninger. Det gjør noe med diskusjonen at møtet er lukket. Personlige relasjoner over partigrensene betyr mye. (Dansk posisjonspolitiker, vår oversettelse)

I utvalgsmøtet kommer mangfoldigheten fram. Alle er ikke enige, men alle kommer til orde, og vi pleier å få til en konstruktiv diskusjon. (Dansk posisjonspolitiker, vår oversettelse)

Hvorfor beskrives partigruppemøtene i norske kommuner som bedre enn utvalgsmøtene, mens de danske utvalgsmøtene beskrives som bedre enn partigruppemøtene? Den viktigste grunnen ser ut til å være at politikerne føler seg friere i møter som er lukket. De kan diskutere uten å tenke på at det de sier, skal «kringkastes» til noen utenfor. Da kan de vise uenighet, men likevel være enige om at de følger det gruppemedlemmene er blitt enige om. De lukkede møtene ser ut til å styrke lagfølelsen blant de som deltar i møtene.

Vi kan være åpne på en annen måte [i lukkede partigruppemøter]. Vi vil helst ikke vise utad at vi har forskjellige meninger. Det er mange gruppemøter der vi i utgangspunktet ikke er enige, men vi blir enige om hvordan vi skal håndtere det som parti. Så da står vi sammen. (Norsk posisjonspolitiker)

Den norske uttalelsen ovenfor viser at de folkevalgte representantene ikke nødvendigvis er enige, men at uenigheten tas opp internt - og at de står samlet utad. Terskelen for å bryte opp fra partiblokken beskrives 
fra flere partier som svært høy, og egentlig som uakseptabel atferd for en lokalpolitiker. I de danske kommunene synes det å være en friere diskusjon i de formelle utvalgsmøtene.

[Med presse til stede] ville man helt klart overveid mer hva man sier. Man stiller ikke sin uvitenhet til skue hvis møtet er offentlig. (Dansk posisjonspolitiker, vår oversettelse)

At utvalget sitter sammen, uten innsyn fra andre, spiller øyensynlig en viktig rolle. Hva mener de danske lokalpolitikerne ville ha skjedd dersom det ble anledning for at presse og tilhørere kunne delta i utvalgsmøtene, slik som i Norge? I alle intervjuene som ble gjennomført, var de danske politikerne opptatt av hvilken betydning lukkede møter hadde for diskusjonen.

Jeg tror at vi med lukkede møter faktisk får noen bedre løsninger, enn hvis møtet var åpent. Vi kan diskutere mer fritt. Det kan godt bli litt mer politisk markering i det åpne møtet i byrådet. (Dansk opposisjonspolitiker, vår oversettelse)

Det er viktig at møtet er lukket. Da kan man bli klokere, og man kan spørre hvis det er noe man lurer på. (Dansk opposisjonspolitiker, vår oversettelse)

Både beslutningene og den politiske prosessen ville blitt annerledes dersom møtene i utvalgene var åpne. Jeg ville ikke likt det, da ville man kun lest opp referater man var blitt enig om i partiet. (Dansk opposisjonspolitiker, vår oversettelse)

Sett fra et norsk perspektiv er det interessant å lese hva de danske lokalpolitikerne uttaler. En av opposisjonspolitikerne som er sitert over, beskriver at de folkevalgte bare ville ha lest opp referater fra sitt partigruppemøte, og at de ville ha debattert på autopilot dersom møtene var åpne. Dette sammenfaller ganske presist med det de norske opposisjonspolitikerne sier: At argumenter ikke nytter ikke i det formelle møtet, og at de som har flertall, har bestemt seg for hva de skal mene i et uformelt og 
lukket formøte i regi av partigruppen. En norsk lokalpolitiker med tilgang til disse formøtene beskriver at føringene herfra gir en slags psykologisk sperre for å endre oppfatning. Selv om det kommer frem argumenter de ikke har tenkt på, fastholder de sin oppfatning av hensyn til partiet og det de er blitt enige om på forhånd.

Vi styrer jo gjennom de vedtakene vi gjør, og det er lettere å få bedre formulerte vedtak i formøtene. Jeg liker ikke å si det, men det kan godt hende at det viktigste møtet er det [lukkede partigruppemøtet] i forkant. (Norsk posisjonspolitiker)

Denne politikeren fra posisjonen oppsummerer inntrykket fra de norske lokalpolitikerne, nemlig at partienes gruppemøter ser ut til å ha stor betydning. I en av de norske kommunene vi studerte, var det vanlig å ha flere ad hoc-baserte, korte partigruppemøter underveis i et kommunestyremøte. I tillegg var det vanlig med løpende dialog via chat innad i partigruppen underveis i det åpne møtet. Partigruppen fremsto med sterk indre tillit og lojalitet, og de kunne diskutere fritt og etablere en lagfølelse i partiet - nesten som en «oss mot dem»-holdning. En lokalpolitiker fra dette partiet beskriver chatten som tidvis ubehagelig, ettersom de etter hennes mening var for frittalende om andre politikeres prestasjoner på talerstolen. Noen ganger kunne uttalelsene være «over kanten», etter hennes mening - på en slik måte at det ble som å «drite ut» politikere fra andre partier. Men siden dette foregikk via chat, var dialogen lukket for andre enn dem som tilhørte det aktuelle partiet.

\section{Det norske åpenhetsparadokset}

På papiret har Norge trolig verdens mest åpne lokalforvaltning gjennom sine radikale regler for møteoffentlighet. Men hvor sikre kan vi være på at norske kommuner dermed også reelt sett er preget av åpenhet? Analysen ovenfor, basert på intervjuer av et utvalg norske og danske kommunepolitikere, tyder på at de politiske arbeidsmøtene - altså der politikerne kan diskutere fritt og uten hensyn til partistrategiske hensyn - er forskjellige i de to landene. De norske lokalpolitikerne er ganske entydige 
på at de beste og mest åpne diskusjonene foregår i partienes gruppemøter. Her slipper de innsyn fra presse eller interessegrupper. De danske lokalpolitikerne er enige $\mathrm{i}$ at partigruppemøtene er gode møter, men når de blir bedt om å rangere, setter de møtene i de kommunale utvalgene høyest. Årsaken er at de får presentert argumenter fra et bredere spekter enn i partigruppemøtene, og alle er godt forberedt og kjenner saksområdet godt. Når de danske folkevalgte blir spurt om hvilken betydning det ville ha hatt at møtet var åpent, svarer alle temmelig entydig at det ville ha vært ødeleggende for møtet som fri arena for diskusjon. Politikerne mener møtene ville ha endret karakter fra arbeidsmøter til det vi har kalt symbolmøter. Dermed tyder analysen på at den norske regelen om møteoffentlighet fører til at partienes gruppemøter får stor betydning. Partiene tilbyr en uformell og lukket arena der politikerne kan diskutere fritt utenfor det formelle systemet.

Diskusjonen og analysen i dette kapitlet har demonstrert at det finnes reelle dilemmaer knyttet til møteoffentlighet, og at ulike hensyn må veies opp mot hverandre. Norsk og dansk kommunelovgivning har valgt å veie hensynene ulikt. Der danskene har vært opptatt av bred debatt og kollegiale beslutningsformer gjennom lukkede møter, har vi i Norge vært mer opptatt av innsyn og ansvarlighet gjennom åpne møter.

I den norske praksisen ser vi imidlertid et paradoks, der reglene om åpne møter i virkeligheten leder til mindre og ikke mer åpenhet. Åpenhetsparadokset oppstår fordi det ikke finnes noen lukkede arenaer i det formelle systemet, og dermed tvinges den frie og brede debatten inn i de politiske gruppemøtene og partiene. På denne måten oppstår deliberasjon, men det er en snever variant som bare omfatter mindre grupper av et kommunestyre, den foregår i lukkede rom, og den fanger neppe opp bredden i ulike kompetanser og tilnærmingsmåter som finnes i et politisk utvalg, et formannskap og et kommunestyre.

De norske reglene for møteoffentlighet er innført med de beste hensikter for å styrke lokaldemokratiets legitimitet. Men resultatet kan være at vi i stedet har fått et demokratisk system der de reelle debattene foregår i lukkede rom, i mindre grupperinger og utenfor det formelle styringssystemet. I verste fall innebærer dette at norske regler for møteoffentlighet truer snarere enn styrker styringssystemets legitimitet. 
Selv om det nødvendigvis må gjøres vanskelige avveininger mellom åpne og lukkede møter, tyder analysen ovenfor på at hensynet til møteoffentlighet har veid for tungt i norsk lovgivning. Dagens regler gir ikke lokalpolitikere i utvalg og kommunestyrer anledning til å diskutere fortrolig med sine politiske kollegaer samlet rundt et bord. Dermed oppnår vi kanskje ikke så mye åpenhet, siden de reelle debattene uansett foregår i lukkede rom. Men vi pådrar oss noen andre problemer. For det første blir ikke hele det politiske fellesskapet inkludert i den frie, gode diskusjonen. For det andre ser det ut til at politikernes oppfatninger fra gruppemøtet lett låser seg før de kommer i det formelle utvalgsmøtet. For det tredje styrkes lojaliteten internt i partiet, på bekostning av de andre partiene. Dette kan gjøre konfliktnivået høyere enn ønskelig. For det fjerde kan reglene bidra til å styrke kommunedirektøren og det politiske A-laget, fordi de gjør det mer effektivt å drive politikk i skyggen av de formelle organene. Ikke minst går dette ut over de små partiene og de mindre rutinerte politikerne. Alt i alt gir studien derfor grunnlag for en debatt om hvordan motstridende hensyn skal veies opp mot hverandre, og om det bør etableres andre balansepunkter enn det dagens kommunelov representerer.

Å endre eller justere på kommunelovens regler for møteoffentlighet vil være en måte å komme disse problemene i møte på. Men i lys av at den gjeldende kommuneloven nylig er vedtatt i Stortinget, og at et samlet storting har sluttet seg til prinsippet om generell møteoffentlighet $\mathrm{i}$ kommunene, virker det ikke sannsynlig at lovteksten vil bli endret i nær fremtid. For den enkelte kommune vil det være mer aktuelt å diskutere og utvikle ulike kompenserende tiltak innenfor rammen av gjeldende regler. Det kan for eksempel skje ved at det enkelte kommunestyret gjerne tidlig i valgperioden - diskuterer og klargjør forventninger om hvilke arenaer man ønsker å utvikle til å bli henholdsvis arbeidsmøter og symbolmøter. På tross av kravet om møteoffentlighet, bør det være mulig for et kommunestyre, en komité eller et utvalg å jobbe mer kollektivt sammen. Men det forutsetter bevisstgjøring og en stor grad av enighet blant de involverte politikerne. I bokens siste kapittel kommer vi tilbake til hvordan et kommunestyre kan sette slike spørsmål på dagsordenen. 


\section{Referanser}

Allison, G. T. (1999). Essence of decision: explaining the Cuban missile crisis.

New York: Longman.

Aukrust, Ø. (2018a). «Ordfører må svare for lukkede møter». Nyhetsartikkel i

Kommunal Rapport. Publisert 24.01.2018. https://www.kommunal-rapport.no/ aapenhet/ordforer-ma-svare-for-lukkede-moter/11778!/ (hentet 17. mars 2020)

Aukrust, Ø. (2018b). «Fylkesmannen: Hemmelige gruppeledermøter er ulovlige»:

Nyhetsartikkel i Kommunal Rapport. Publisert 02.03.2018. https://www.

kommunal-rapport.no/aapenhet/fylkesmannen-hemmelige-gruppeledermoterer-ulovlige/91467!/

(hentet 17. mars 2020)

Bentham, J. (2001 [1790s]). Writings on the Poor Laws (Vol. 1). Oxford, England: Oxford University Press.

Elster, J. (1998). Deliberative democracy. Oxford, England: Oxford University Press. Fung, A., Graham, M. \& Weil, D. (2007). Full disclosure. The politics, perils and promise of targeted transparency. Cambridge, England: Cambridge University Press.

Gedde-Dahl, S., Hafstad, A. \& Magnussen, A. E. (2008). Korrupsjon i Norge. Oslo: Kagge forlag.

Habermas, J. (1995). Tre normative demokratimodeller: Om begrepet deliberativ politikk. I Erik O. Eriksen (Red.), Deliberativ politikk. Demokrati i teori og praksis. Oslo: Tano.

Heald, D. (2006). Varieties of transparency. I C. Hood \& D. Heald (Red.), Transparency: the key to better governance? (Vol. 135). Oxford, England: Oxford University Press.

Indenrigsministeriet. (1977). Kommunalt nordemokrati. Redegørelse afgivet af en arbejdsgruppe nedsat af indenrigsministeriet. Betcenkning nr. 798. København: Indenrigsministeriet.

Jørgensen, T. \& Bozeman, B. (2007). Public values: An inventory. Administration \& Society, 39(3), 354-381. https://doi.org/10.1177/0095399707300703

Kommunal- og moderniseringsdepartementet. (2010). Endringar i kommuneloven (møteoffentlegheit). Prop 152 L (2009-2010). Hentet fra https:/www.regjeringen.no

Leirset, E. (2019). Er norske kommuner for åpne? Nytt norsk tidsskrift, 36(1), 21-30.

Mansbridge, J. (2009). A «selection model» of political representation. Journal of Political Philosophy, 17(4), 369-398. https://doi.org/10.18261/issn.1504-3053-201901-03

NOU 1990: 13. (1990). Forslag til ny lov om kommuner og fylkeskommuner. Hentet fra https://www.regjeringen.no

NOU 2016: 4. (2016). Ny kommunelov. Hentet fra https://www.regjeringen.no 
Przeworski, A. (1987). Methods of cross-national research, 1970-83: An overview.

I M. Dierkes, H. N. Weiler \& A. B. Antal (Red.), Comparative policy research. Learning from experience. Berlin, WZB-Publications.

Regjeringen (2010). Endringar i kommuneloven (møteoffentlegheit). Proposisjon til Stortinget. Oslo: Regjeringen

Restad, H. (2018). WikiLeaks. Hentet fra https://snl.no/WikiLeaks

Schmidt, V. A. (2008). Discursive institutionalism: The explanatory power of ideas and discourse. Annual Review of Political Science, 11(1), 303-326.

Sirevåg, T. (2019). Watergate-saken. Hentet fra https://snl.no/Watergate-saken

Sletnes, I., Henrichsen, C., Lundin, O. \& Mäkinen, E. (2013). Kommunelovene $i$ Norden. En kartlegging og sammenligning. Oslo: Høgskolen i Oslo og Akershus.

Stiglitz, J. E. (2008). Information. I D. R. Henderson (Red.), The Concise

Encyclopedia of Economics. Hentet fra: https://www.econlib.org/library/Enc1/ Information.html

Torfing, J., Peters, B. G., Pierre, J. \& Sørensen, E. (2012). Interactive governance. Advancing the paradigm. Oxford, England: Oxford University Press.

Tucker, R. (1995). Politics as leadership (Rev. utg.). Columbia, MO: University of Missouri Press. 


\section{Strengere enn på Stortinget}

Tekst: Espen Leirset og Asbjørn Røiseland. Intervju foretatt 27. august 2019 (Kåss) og 3. oktober 2019 (Five).

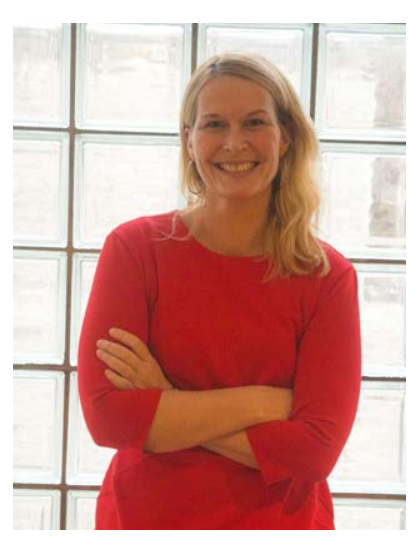

LEDERMØTE: «Jeg ønsket å bruke gruppelederne som et ledermøte der jeg kan få innspill til hvordan en sak bør håndteres. Men hvis disse møtene skal ha en pressebenk, mister de sin funksjon», sier ordfører Hedda Foss Five i Skien. (Foto: Bjørn Rudborg. Bildet er gjengitt med tillatelse og omfattes ikke av bokens lisens.)

STRENGERE: «Jeg tror ikke Stortinget har tatt innover seg at de har pålagt landets lokalpolitikere et langt strengere regelverk enn de selv har på Stortinget», sier ordfører Robin Kåss i Porsgrunn kommune. (Foto: Hege Schjøth Øverås. Bildet er gjengitt med tillatelse og omfattes ikke av bokens lisens.)

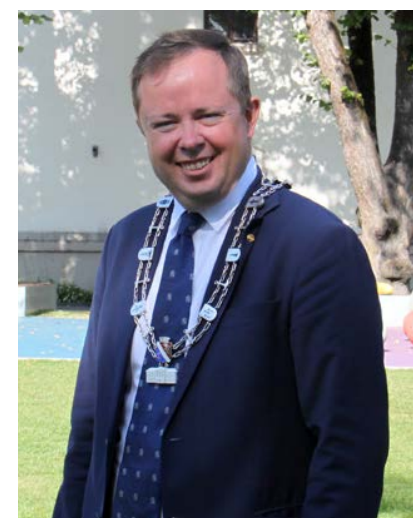

Ordførerne Hedda Foss Five og Robin Kåss mener at det er et paradoks at Stortinget har pålagt kommunepolitikere strengere regler for møter enn stortingspolitikerne selv har. «De strenge reglene gjør arbeidsforholdene for oss som lokalpolitikere mye vanskeligere», sier Five.

For noen år siden skjedde et tragisk drap i Skien, byen som Hedda Foss Five leder. Da ble oppmerksomheten rettet mot et rusmiljø i byen, og kommunens rolle ble etterspurt. Ordføreren måtte svare på spørsmål om hvordan kommunen jobbet forebyggende mot dette miljøet, og om 
hvordan hun skulle håndtere krisen som hadde oppstått. «Da følte jeg veldig på å orientere gruppelederne på hva som faktisk hadde skjedd, samt at jeg ønsket råd og innspill på hvordan jeg som ordfører skulle håndtere saken. Men at jeg hadde møte med gruppelederne uten at pressen var invitert, ble sterkt kritisert av media. Derfor har jeg blitt nødt til å slutte med det», sier Skien-ordføreren.

\section{Strengest i Norden}

I dette intervjuet forklarer hun og ordførerkollega Robin Kåss i nabobyen Porsgrunn noen paradokser de opplever rundt kravet om åpne møter i kommune-Norge. De har begge erfart store oppslag i lokalpressen og klager til Fylkesmannen om gruppeledermøter. Møtene i begge kommunene ble erklært som ulovlige, med henvisning til paragrafen om møteoffentlighet $\mathrm{i}$ kommuneloven.

Kommuneloven inneholder strenge regler om møteoffentlighet i kommunal saksbehandling. Politikere har etter loven ikke anledning til å møtes uformelt for å diskutere aktuelle saker dersom de sitter sammen $i$ et utvalg eller formannskap. De strenge kravene om møteoffentlighet i Norge er de strengeste i Norden. «Reglene gjør det vanskelig å drive lokalpolitikk», mener Hedda Foss Five.

\section{Ledermøte}

«Jeg forstår godt at beslutninger som har en konsekvens for innbyggerne, skal være offentlig. Men at vi ikke får lov til å prate fortrolig sammen om aktuelle saker, det forstår jeg ikke. Som ordfører trenger jeg råd fra andre politikere. Jeg ønsket å bruke gruppelederne som et ledermøte der jeg kan få innspill til hvordan en sak bør håndteres. Og jeg kan dele informasjon jeg har fått med de andre. Men hvis disse møtene skal ha en pressebenk med journalister, mister de sin funksjon. Da vil ikke folk våge å tenke høyt og komme med råd til meg som ordfører», sier Foss Five.

Hun synes mediekritikken om de «hemmelige» gruppeledermøtene var svært urimelig. «Jeg ble fremstilt som en hemmelighetstyrann fordi 
jeg mener vi har behov for å diskutere noen ting fortrolig. I omtalen av disse sakene sitter media med all makt. De beskriver seg selv som demokratiets voktere, og argumenterer som om åpne møter er det samme som demokrati», sier Foss Five.

Erfaringen hennes er at det er umulig å forsvare behovet for fortrolige politikerfora. Debatten er umulig å vinne. Derfor er praksisen med gruppeledermøter i Skien nå avsluttet. I stedet ringer Foss Five til hver enkelt gruppeleder etter behov. Ordføreren skal snart ha konstituerende møte etter valget i 2019, og nedenfor beskriver hun problemene regelen fører med seg.

\section{Firkantet regel}

«Jeg trenger å snakke med partiene som en del av forarbeidet med å avklare hvem de skal ha i utvalgene. Jeg er også tillitsvalgt for bystyret. Partiene skal kunne komme til meg, som ordfører, fra alle partier. Det må de få lov til uten at fylkesavisene skal sitte rundt bordet. Jeg synes denne regelen er svært firkantet og frustrerende og gjør det vanskeligere å være lokalpolitisk leder», sier Foss Five, og fortsetter:

«Jeg føler jeg strekker meg for å være åpen og ha god service overfor pressen. Men nå merker jeg at jeg lukker meg mer, etter kritikken jeg fikk. Jeg føler på et vis at det aldri blir nok åpenhet. Jeg blir påvirket av det. Jeg ble beskrevet som antidemokratisk fordi jeg mente vi som er folkevalgte, har behov for et fortrolig rom å diskutere i. Det synes jeg var dypt urettferdig, og det føler jeg fortsatt på. Det er ingen respekt for at grensa mellom fortrolighet og åpenhet skal gå noe sted. Det virker som alle telefoner, alle mailer, alle møter i ulike fasonger forventes å være åpne, hvor journalister skal delta. Det synes jeg blir feil», sier Skien-ordføreren.

Hun mener regelen helt klart gjør det vanskeligere å drive konsensusbasert politikk. «Det styrker konfliktene i lokalpolitikken, det er det ingen tvil om. Men dette er jo noe også media ønsker. Media vil gjerne dyrke frem mer konflikt, fordi det er mer spennende å skrive om», sier ordføreren.

Hun mener det trengs en nasjonal debatt om lokalpolitikernes arbeidsforhold. «Det kan ikke være intensjonen at loven skal fungere slik den nå gjør. Det gjør arbeidsforholdene for oss som lokalpolitikere mye 
vanskeligere. Jeg visste heller ikke at Norge har strengere regler for åpenhet enn andre land i Norden. Dette angår jo alle kommuner her til lands, iallfall de som drives etter formannskapsmodellen. Derfor bør KS sette seg grundigere inn i saken og jobbe for å finne bedre løsninger for landets lokalpolitikere», mener Foss Five.

\section{Kommuner mest åpne}

Hun får støtte fra ordførerkollega Robin Kåss i Porsgrunn. Han hadde erfaring som statssekretær i Helsedepartementet da han ble valgt som ordfører i 2015. I ordførerrollen erfarte han raskt at det var andre regler som gjaldt enn i departementet, siden kravet om åpenhet er langt større.

Før Kåss ble ordfører, var det fast praksis at gruppelederne i kommunen møttes forholdsvis hyppig. Her kunne ordføreren gi informasjon til de andre folkevalgte om aktuelle saker under oppseiling, og de diskutere hvordan den videre politiske prosessen burde være. Fordelen med dette var at hele det politiske fellesskapet ble informert på et tidlig tidspunkt, før saken var offentlig.

«Gruppeledermøtet var en arvet praksis som jeg også fant nyttig. De kunne ta med seg informasjonen til sine partier, og jeg tror vi fikk bedre politiske prosesser av det. Særlig var dette nyttig for de mindre partiene. Da kunne alle partiene få likelydende informasjon på et tidlig stadium», forklarer Kåss.

Problemet er altså at slike møter ikke er tillatt etter dagens kommunelov. Da lokalavisen Varden klaget på møtepraksisen til Fylkesmannen, fikk avisen medhold. Møtene manglet sakliste, referat og adgang for pressen - og ble i lokalpressen beskrevet som «hysj-møter» eller «hemmelige møter». Konklusjonen ble at gruppeledermøtene måtte opphøre.

\section{Verst for de små}

«Jeg tror ingen så for seg denne strenge praksisen da kommuneloven ble vedtatt tidlig på 1990-tallet. Det gjør det vanskelig for oss som lokalpolitikere å ha gode møteplasser og etablere gode politiske prosesser der hele 
det politiske fellesskapet deltar. Særlig for de mindre partiene blir dette vanskelig. Det er de som har mest å hente på å få ta del i åpne og frie diskusjoner mellom partiene», erfarer Kåss.

Sivilombudsmannen har dertil definert begrepet «saksbehandling» svært vidt. Det betyr at dersom et utvalg eller et formannskap, eller alle gruppelederne som representerer hele kommunestyret, treffes uformelt for å diskutere en sak i en tidlig fase, er det å anse som saksbehandling. Det er altså ikke tillatt. Lovens vide definisjon av saksbehandling gjør det også vanskelig å trekke opp en klar grense. Når driver man «saksbehandling» i lovens forstand, og når gjør man det ikke? Kåss bruker et eksempel der hele kommunestyret samles til en årlig middag. Hvis det på dette møtet blir en diskusjon om eksempelvis skolestruktur, er det da tillatt å diskutere saken? «Slik jeg forstår regelverket, er det ikke tillatt med slike diskusjoner i en slik setting. Da skulle vi ha annonsert det som møte, og sendt ut innkalling og åpnet det for alle sammen. Det er jo en merkelig situasjon at vi som lokalpolitikere ikke skal kunne snakke sammen på tvers av partigrensene, uten å sende ut sakliste og åpne møter. Jeg mener regelverket ikke fungerer helt godt», sier Kåss.

\section{Fortrolighet nødvendig}

Da Kåss arbeidet som statssekretær under Jonas Gahr Støre i Helsedepartementet, erfarte han hvordan arbeidet foregår mellom regjeringen og Stortinget. Her beskriver han utstrakt fortrolighet i saksdiskusjoner mellom fraksjonsgrupper og komiteer i Stortinget og departementet. «Denne fortroligheten var avgjørende for å skape gode løsninger», sier han. At komiteene på Stortinget skulle være åpne for allmennheten, slik kommunale utvalg og formannskap er, tror han ville ha hatt dramatisk og negativ betydning for Stortingets virke.

«Det er nesten umulig å se for seg at disse møtene skulle ha vært åpne. Det ville ha gjort det langt vanskeligere å få frem politiske kompromiss», mener Kåss. Han tror den strenge tolkingen av åpne møter som praktiseres av Sivilombudsmannen - og som dermed skaper presedens overfor alle landets fylkesmenn - har vært en ikke-tilsiktet konsekvens av møteoffentlighetsprinsippet som ble innført i 1993. 


\section{Flytter makt}

«Jeg tror ikke Stortinget har tatt innover seg at de har pålagt landets lokalpolitikere et langt strengere regelverk enn de selv har», kommenterer Kåss. I tillegg til at det blir vanskeligere å bygge politiske kompromisser på tvers av partigrensene, erfarer han at ordningen også bidrar til å flytte makt fra det folkevalgte nivået - og til kommunens administrasjon.

«En sak kan forberedes ganske lenge og grundig i lukkede rom i administrasjonen. Det kan legges ganske mange premisser i denne fasen, og her har ingen folkevalgt adgang. Først når saken blir offentlig, blir det en politisk sak. I praksis betyr dette at politikerne mister en del innflytelse til det administrative nivå», mener Kåss. Rådmannen oppfattes for øvrig å ha en mektigere rolle i norske kommuner enn det som er tilfellet $i$ andre lands kommuner.

Kåss tror en løsning kunne ha vært at politikerne kunne inkluderes i en sak litt før saken ble offentlig. «Jeg tror vi burde skilt mellom saksbehandling og forberedelse til en sak. Vi burde få ha anledning til å forberede oss på en sak og diskutere litt friere i en tidlig fase. Det er noe jeg savner med dagens ordning. Jeg tror dette kunne bidratt til bedre politiske prosesser», sier Porsgrunn-ordføreren.

\section{Delt på midten}

Et liknende forslag ble satt på dagsordenen da kommuneloven ble gjennomgått av et offentlig utvalg (NOU) i 2016. Utvalget delte seg på midten i dette spørsmålet. Et mindretall ønsket mulighet for at et utvalg eller formannskap kunne diskutere en sak i et fortrolig forum i en tidlig fase, nettopp for å gjøre den politiske prosessen bedre og for lettere å kunne inkludere hele det politiske fellesskapet. Dette ble nedstemt av et knapt flertall, som argumenterte ut fra hensynet til demokratisk kontroll, altså at borgerne skal kunne føre kontroll med de folkevalgte. De ønsket derfor å beholde regelen om møteoffentlighet slik den var, og dette ble også forslaget fra utvalget. Loven ble vedtatt i Stortinget våren 2018, uten videre debatt om akkurat dette spørsmålet. 


\title{
Demokratiparadokset Hvordan styre et folk som skal styre seg selv?
}

\author{
Jacob Torfing
}

Roskilde universitet

\section{Marte Winsvold}

Universitetet i Oslo, Institutt for samfunnsforskning

\begin{abstract}
In this chapter we discuss what we have conceptualized as "the paradox of democracy", pointing to the conflict between the idea of the sovereign people on one side, and the idea that democracies need representatives and political leaders, on the other. The chapter gives an overview of democratic arrangements that encourage direct participation, including arrangements that feed into and support and arrangements that challenge the representative system. Furthermore, the chapter provides examples of arrangements that actively and intentionally link together representation and direct participation. Lastly, we discuss how the tension between participatory practices and representative democracy can be solved. In a brief and subsequent chapter, a Norwegian Mayor reflects on the conflict between representation and direct participation.
\end{abstract}

Keywords: political leadership, direct democracy, representative democracy, local government

\section{Introduksjon}

I det representative demokratiet ligger en iboende spenning mellom representasjon og deltakelse. Demokrati betyr jo «folkestyre» og innebærer at folket skal styre seg selv. I samfunn over en viss størrelse er det vanskelig å få til at folket styrer direkte, og derfor velger innbyggerne

Sitering av denne artikkelen: Torfing, J. \& Winsvold, M. (2020). Demokratiparadokset. Hvordan styre et folk som skal styre seg selv?. I A. Røiseland \& S. I. Vabo (Red.), Folkevalgt og politisk leder (Kap. 5, s. 120-145). Oslo: Cappelen Damm Akademisk. https://doi.org/10.23865/noasp.8o.ch5

Lisens: CC BY-ND 4.o. 
representanter som gis mandat til å styre på deres vegne i en gitt periode, og som må stå til ansvar ved hvert valg. De folkevalgtes oppgave er dermed å styre et folk som skal styre seg selv - men vel vitende om at den egentlige makten ligger hos folket.

Tilsynelatende er dette paradokset løst gjennom det representative demokratiet. Representanter velges, styrer i den perioden de er valgt for, og velges eller velges ikke på nytt etter endt periode. Så folket styrer seg selv - gjennom sine representanter. Men hva når innbyggere i en kommune mener noe om hvordan samfunnet bør styres, også i periodene mellom valg? I praksis har folk ofte mer på hjertet enn de får gitt uttrykk for på selve valgdagen. Saker som folk kanskje mener noe om, dukker opp. En kommunereform lanseres, ungdomskriminaliteten øker, tilflytting gjør at det oppstår boligmangel. Eller folk mener kanskje noe om sakene som allerede sto på den politiske dagsordenen, men ønsker ikke å kanalisere engasjementet sitt gjennom partisystemet. Det representative demokratiets paradoks består i at det skal være tro både mot prinsippet om det suverene folks kollektive selvbestemmelse og mot forestillingen om at våre valgte politiske ledere har makten og ansvaret for å treffe gode og kloke beslutninger som løser presserende problemer og bringer samfunnet videre (Kane \& Patapan, 2012). Den politiske makten skal altså på en og samme tid ligge hos folket og de politiske lederne. I dette kapitlet ser vi nærmere på hvordan det arbeides lokalt med å løse opp i spenningen mellom representativt demokrati og innbyggerdeltakelse i norske og danske kommuner. Vi vil beskrive hvilke måter folk kan delta på mellom valg, hvilke måter de faktisk deltar på, og hvordan politikere avveier mellom å lede på bakgrunn av det mandatet de har fått ved valg, og ut fra innbyggernes innspill. Til sist diskuterer vi hvordan innslag av direkte demokrati kan sies å gjøre styringen mer eller mindre demokratisk. Før vi beskriver hvordan spenningen mellom representativt og direkte demokrati håndteres i praksis, redegjør vi imidlertid for hvordan denne spenningen omtales i den teoretiske litteraturen. 


\section{Bestemme selv - eller bestemme hvem som skal bestemme?}

Demokrati er en styringsform basert på kollektiv selvbestemmelse; folket bestemmer over seg selv, men i fellesskap og på vegne av fellesskapet. Både små og store fellesskap kan styres demokratisk. I Norge og Danmark styres det nasjonale, regionale og lokale nivået demokratisk, men også mindre, sosiale fellesskap som for eksempel en velforening, et idrettslag eller en arbeidsplass styres ofte med utgangspunkt i demokratiske verdier og normer som toleranse, likeverd og lydhørhet. Verdiene som demokratiet er tuftet på, står sterkt i de skandinaviske samfunnene og representerer viktige målestokker for hva vi oppfatter som god styring.

At folket oppfattes som suverent, betyr at det ikke er noen over eller ved siden av folket som kan utfordre folkets rett til å bestemme over seg selv og sine egne anliggender. Beslutninger skal ikke dikteres, verken av næringslivsledere, religiøse ledere, monarker eller byråkrater, men skal være resultat av demokratisk meningsutveksling hvor forskjellige synspunkter fremføres, underbygges, støter sammen og gir anledning til revisjoner i en felles bestrebelse på å nå frem til gode beslutninger. I denne meningsutvekslingen er alle innbyggere i prinsippet like, i den forstand at alle skal stå fritt og ha like muligheter til å delta i demokratiske diskusjoner og avgjørelser. Alle argumenter har samme krav på å bli hørt, og i avstemninger gjelder prinsippet «én person - én stemme». Den demokratiske forestillingen om det suverene, selvbestemmende folk har således likhet som et bærende prinsipp, fordi alle innbyggere har samme innflytelse på den politiske styringen av samfunnet.

I dagens vestlige massedemokratier er det umulig å forestille seg at alle innbyggere skal være permanent involvert i diskusjonen omkring og avgjørelsen av alle felles anliggender. Det var kanskje mulig i antikkens små bystater å møtes på torget for å styre i fellesskap, men det lar seg ikke gjøre i moderne nasjonalstater eller kommuner der det både er mange flere saker og der befolkningen i de fleste tilfeller er mye større. Derfor velger innbyggerne i det representative demokratiet politiske ledere som kan styre på deres vegne. Den demokratiske valghandlingen kan beskrives som en delegasjons- og kontrollprosess. Først delegerer velgerne makt 
til de folkevalgte politikerne, og siden utøver de kontroll ved neste valg, hvor de gjennom sin stemmegivning har mulighet for henholdsvis å belønne og straffe politikerne for måten de har utøvd vervet sitt på.

Innbyggerne forventer av de folkevalgte at de skal utøve politisk lederskap, altså at de skal definere hvilke problemer som kaller på kollektiv handling, at de skal utvikle nye felles løsninger, og at de skal mobilisere støtte slik at disse løsningene kan iverksettes (Tucker, 1995). Det er kanskje mange kommunepolitikere som ikke oppfatter seg som politiske ledere, men det er faktisk kommunepolitikerens oppgave å ivareta de politiske lederskapsfunksjonene på lokalt nivå. Det er viktig at det tas lokalpolitisk lederskap, fordi det er nødvendig at noen står i spissen for og gir retning til samfunnsutviklingen. Velgerne ønsker også politikere som har visjoner og utviser handlekraft, og de vurderer politikerne ut fra deres evne til å utøve politisk lederskap (Karsten \& Hendriks, 2017).

Den demokratiske forestillingen om det suverene folk står i kontrast til forestillingen om suverent politisk lederskap, som grunnleggende sier at de folkevalgte politiske ledere har både makt og autoritet til å treffe alle viktige politiske beslutninger i samfunnet. Kontrasten er på sett og vis grunnet i det faktum at den politiske ledelsestenkningen ble utviklet mye tidligere enn den moderne demokratitenkningen. Den politiske ledelsestenkningen går tilbake til Platon, som betonet de kloke og innsiktsfulle filosofers rolle som politiske ledere. Dette synet på ledere som overordnet folket fremkommer også hos Machiavelli, som mener at det er nødvendig for ledere å bruke alle knep for å vinne, utøve og beholde politisk makt. Det suverene politiske lederskap rendyrkes hos Hobbes, som ser herskerens absolutte maktutøvelse som selve betingelsen for etableringen av sosial orden i samfunnet.

Motsetningen mellom det suverene og selvstyrte folk og det suverene politiske lederskap løses på sett og vis - i hvert fall i teorien - ved at de politiske lederne velges av folket og dermed er folkets representanter: De politiske lederne kommer fra folket, er utpekt av folket og kontrolleres av folket. I praksis fjernes imidlertid ikke motsetningen helt. For det første er den politiske representasjonsrelasjonen ofte svak, på den måten at politikere og innbyggere har nokså lite kontakt. I et samfunn av en viss størrelse har politikerne bare tid og kapasitet til å kjenne og snakke med 
en liten andel av befolkningen, og politikerne har derfor nødvendigvis begrenset informasjon om hvorfor velgerne har stemt på dem, hva velgerne ønsker, og hva de forventer av politikerne. Det er også bare en liten andel av befolkningen (2-3 prosent i Norge og Danmark) som er medlem i politiske partier. Det gjør at dialogen mellom folket og de folkevalgte kan bli sparsom, i hvert fall dersom politikerne selv ikke aktivt gjør noe for å ha kontakt med velgerne. Konsekvensen er i så fall at man ikke kan forvente at det skal være samklang mellom politikernes og innbyggernes politiske holdninger.

For det andre er det en tendens til at politiske ledere oppleves å fjerne seg fra det folket de skal representere (Winsvold, Rose \& Klausen, 2017). Noe av forklaringen på at det blir en slik opplevd avstand, kan ha å gjøre med utøvelsen av vervet som folkevalgt. De som velges til å være folkets representanter, får også ansvar for å fatte beslutninger. De tvinges til å tenke på hvordan det skal prioriteres mellom saker, de tilegner seg kunnskaper om og innsikt i hele kommunens virke, og de begynner kanskje å se på seg selv som «kvalifiserte beslutningstakere», til forskjell fra «vanlige folk».

Den stadige spenningen mellom demokrati og politisk ledelse viser seg blant annet ved at de demokratiske institusjonene er opptatt av å føre oppsyn med og begrense makten til de politiske lederne - for å sikre at de ikke går ut over det mandatet de er gitt av velgerne, og for å hindre at de misbruker den makten de har fått (Kane \& Patapan, 2012). Riktignok bidrar demokratiet til å velge ut og gi autoritet til de politiske lederne, men gjennom demokratiske prosedyrer blir også de politiske lederne kontrollert og hindret i å ende med å utgjøre en selvsupplerende politisk klasse ute av takt med befolkningens holdninger, ønsker og behov. I perioder hvor de politiske lederne opptrer litt for suverent og fjerner seg for mye fra folk, står populistiske bevegelser klar med kritikk av den politiske elitismen. Selv om dette kan tjene som et nødvendig korrektiv, bidrar ikke populismen nødvendigvis til å skape bedre kontakt og dialog mellom politiske ledere og folket som helhet. Populistiske ledere er ofte karismatiske personer som gjerne taler på vegne av folket, men som ikke nødvendigvis taler med folket (Stoker, 2019).

Gitt at det - om enn i varierende grad - er et spenningsforhold mellom den demokratiske logikken som handler om å gi alle lik innflytelse, 
og den politiske lederskapslogikken som handler om å sikre noen få utvalgte politisk handlekraft, melder spørsmålet seg om hvordan denne spenningen kan løses opp. Utviklingen av «samskapt politikk» (Ansell \& Torfing, 2017) og «hybriddemokrati» (Sørensen \& Torfing, 2019a) gir nye muligheter for å håndtere spenningen. Samskapt politikk er betegnelsen for nye måter å sikre input til de folkevalgtes politikkutvikling på gjennom intensivert dialog med innbyggere og relevante interessenter. Både norske og danske kommuner har eksperimentert med nye interaktive deltakelsesformer som bringer politikere og innbyggere sammen i kreative problemløsningsprosesser. Faktisk forsøker folkevalgte forsamlinger over hele verden å skape nye arenaer for innbyggerdialog (Beetham, 2006; Neblo, Esterling \& Laser, 2018). Et hybriddemokrati søker å knytte representativt demokrati sammen med nye former for direkte deltakerdemokratier basert på deliberasjon mellom innbyggere og politikere. Her er det typiske en åpen og søkende prosess hvor innbyggere og politikere i fellesskap utvikler nye forståelser av politiske problemer og utfordringer som utgangspunkt for forslag til nye og innovative løsninger. Rammen rundt prosessene er bestemt av folkevalgte organer, for eksempel kommunestyret, som også i siste instans tar stilling til de forslagene som fremmes. På den måten kan det, ifølge Sørensen og Torfing (2019b), over tid utvikle seg et fruktbart samspill mellom representative og deltakelsesbaserte demokratiformer.

\section{Hvordan kan folk delta i politikkutviklingen mellom valg?}

Politisk valgte representanter stilles overfor den tilsynelatende umulige oppgaven å styre et folk som skal styre seg selv. I det videre viser vi hvordan valgte politikere forsøker å løse dette oppdraget ved - på den ene siden - å styre innenfor den representative styringskjeden som tillater folket å holde de folkevalgte til ansvar, og - på den andre siden - ved å styre i samarbeid og dialog med innbyggerne, hvilket sikrer at folket $\mathrm{i}$ større grad styrer seg selv, også i periodene mellom valg.

Som nevnt innebærer den representative styringskjeden at folk gjennom valg utpeker representanter som kan styre på folkets vegne i en 
fireårsperiode av gangen. Ved valg har hver enkelt innbygger som har nådd stemmerettsalderen, én stemme. På lokalt nivå betyr det at alle som er bosatt i en kommune, har akkurat like stor innflytelse over valget av representanter. Innbyggerne bruker den demokratiske styringsmuligheten sin kun én gang hvert fjerde år, mens det mellom valg er de folkevalgte som driver samfunnsutviklingen og fatter beslutninger på innbyggernes vegne. Kontrakten med velgerne er at de folkevalgte etter beste evne skal forsøke å gjennomføre det programmet de har gått til valg på. Etter fire år vurderer velgerne om de mener politikerne har lykkes - og på den bakgrunn om de skal gi dem som har vært folkevalgt i perioden, fornyet tillit, eller om de skal stemme på noen andre. Men lokaldemokratiet utøves ikke bare gjennom den representative styringskjeden. For det første finnes det en rekke formelle ordninger for at innbyggerne skal kunne utøve innflytelse også i periodene mellom valg, og for det andre øver velgerne i praksis innflytelse også gjennom uformelle kanaler. I det videre skal vi kort skissere de mest brukte formelle og uformelle kanalene innbyggerne øver innflytelse gjennom i norske kommuner. Vi har også med noen eksempler fra danske kommuner.

\section{Lovfestede deltakelsesordninger}

I Norge er det lovfestet at innbyggerne skal involveres i lokal politikkutforming i periodene mellom valg på tre måter: gjennom høringer, gjennom ordningen med innbyggerforslag og gjennom råd for særlige grupper. Disse ordningene gir innbyggerne mulighet for å komme med innspill på forskjellige trinn i politikkutformingsprosessen (illustrert i kapittel 1). Mens høringsinstituttet gir innbyggerne mulighet for å gi innspill til saker som allerede er på dagsordenen, så gir ordningen med innbyggerforslag mulighet til å sette saker på dagsordenen. Særgrupperådene åpner både for å sette dagsorden og for å komme med innspill til saker som politikerne eller administrasjonen har satt på dagsordenen. Ingen av de lovpålagte ordningene gir innbyggere noen beslutningsmyndighet.

Høringsinstituttet åpner for at de som er berørt i en sak, skal ha mulighet til å uttale seg i saken. På lokalt nivå er det lovfestet at for eksempel kommuneplanen, som legger rammer for kommunens politikk, skal ut på 
høring (plan- og bygningsloven, 2008, \$ 11-14). Fordi hele befolkningen i en kommune potensielt er berørt av kommuneplanen, har hele befolkningen krav på å bli hørt. Høringer foregår på ulike måter. Det vanligste er å arrangere åpne folkemøter der alle innbyggerne i en kommune inviteres til å møte opp og si hva de mener om for eksempel kommuneplanen eller en annen sak (Monkerud et al., 2016).

Også når grensene for en kommune skal endres, for eksempel ved at den skal slå seg sammen med en annen kommune, sier loven at kommunestyret bør innhente innbyggernes synspunkter på forslag til grenseendring (inndelingsloven, 2002, \$ 10). I forbindelse med kommunereformen, som ble lansert i Norge i 2014, har kommunene hørt folket på ulike måter. I et flertall av kommunene ble det gjennomført rådgivende folkeavstemninger der man spurte innbyggerne om hvorvidt de ønsket å slå seg sammen eller ikke. Andre måter folket ble hørt på i kommunesammenslåingsprosessen, var gjennom spørreundersøkelser eller gjennom folkemøter (Stigen, Kolltveit \& Winsvold, 2018).

Innbyggerforslag er en lovfestet rett som innbyggere i alle landets kommuner og fylkeskommuner har til å få behandlet en sak i kommunestyret (kommuneloven, 2019, \$39a). Det stilles visse krav for å få satt en sak på dagsordenen. For det første må forslagsstiller samle støtte i form av underskrifter fra minst 300 av kommunes innbyggere (500 i store kommuner, 2 prosent av folketallet i små kommuner). For det andre kan ikke saken ha vært tatt opp i inneværende valgperiode. Dersom en sak innfrir disse kravene, så plikter kommunestyret å behandle saken innen seks måneder. En evaluering av ordningen i 2010 viste at nesten 40 prosent av innbyggerforslagene ble avvist før de kom til behandling fordi de ikke innfridde lovens krav (Christensen et al., 2010). Ordningen ble likevel vurdert av både politikere og de innbyggerne som brukte den, som et positivt tilskudd til demokratiet, og som en sikkerhetskanal til bruk for innbyggerne når de ikke kunne få politikere direkte i tale.

Råd for sarlige grupper er kommunale råd som gjerne består av noen politikere fra kommunestyret og av representanter for en bestemt befolkningsgruppe. Tre slike råd er lovfestet: eldreråd, ungdomsråd og råd for mennesker med nedsatt funksjonsevne (kommuneloven, 2019, $\$$ 5-12). I tillegg har en rekke kommuner et råd der innvandrere er spesielt 
representert (og som kan gå under navn som integreringsråd, mangfoldsråd eller innvandrerråd). Utover dette finnes det en rekke typer råd som er spesielle for hver enkelt kommune. Slike råd får alle saker som skal opp i kommunestyret, til høring, og rådene får mulighet til å uttale seg. Rådene kan også spille inn saker til kommunestyret, men kommunestyret har ingen plikt til å ta opp de sakene som spilles inn. En evaluering av ordningen i 2014 viser imidlertid at medlemmene av disse rådene opplever at de har ganske stor innflytelse, og at kommunestyret ofte tar hensyn til innspill de kommer med (Winsvold et al., 2014).

\section{Ordninger utenom de lovfestede}

I tillegg til de lovpålagte ordningene er det i mange kommuner innført ordninger som gjør at innbyggerne kan komme med innspill, enten til dagsordenen eller til hvordan oppgaver skal løses. Tabell 5.1 nedenfor viser hvor stor andel av de norske og danske kommunene som hadde innført ulike typer ordninger i 2018.

Tabell 5.1 Tiltak for å innhente innspill fra innbyggerne og legge til rette for deltakelse. Prosent av kommunene som tilbød ulike tiltak i 2018. Kilde: Bentzen, Lo \& Winsvold, 2019.

\begin{tabular}{|c|c|c|}
\hline & Norge & Danmark \\
\hline $\begin{array}{r}\text { Åne møter, ut over planlovens minstekrav, der innbyggerne kan } \\
\text { komme med innspill til politikkutvikling }\end{array}$ & 60 & 71 \\
\hline $\begin{array}{l}\text { Ordninger eller arenaer som legger til rette for at innbyggerne kan } \\
\text { involveres i diskusjoner om prioriteringer mellom ulike behov }\end{array}$ & 49 & 81 \\
\hline $\begin{array}{r}\text { Prosedyre for regelmessig kontakt med frivillige organisasjoner og } \\
\text { andre sivilsamfunnsaktører }\end{array}$ & 44 & 67 \\
\hline $\begin{array}{r}\text { Digitale løsninger som innbyggerne bruker for å kommentere på } \\
\text { politiske forslag }\end{array}$ & 43 & 57 \\
\hline $\begin{array}{r}\text { Utvalg eller komiteer hvor både valgte politikere og andre } \\
\text { (enkeltborgere, næringslivsrepresentanter, frivillige } \\
\text { organisasjonsliv osv.) er fullverdige medlemmer }\end{array}$ & 37 & 71 \\
\hline Kommunedelsutvalg eller samarbeid med lokalt initierte lokalutvalg & 17 & 51 \\
\hline Deltakende budsjettering & 3 & 17 \\
\hline Utvalgsantall (N) & 314 & 84 \\
\hline
\end{tabular}


To tendenser springer oss i øynene når vi kikker på tabellen over deltakelsestiltak. For det første har langt flere danske kommuner enn norske gjennomført slike tiltak. Vi kan bare spekulere i hva dette skyldes, men tidligere forskning har vist at det deliberative idealet, som innebærer at innbyggerne og politikere skal diskutere seg frem til omforente løsninger, står spesielt sterkt i Danmark (Aarts et al., 2014).

For det andre viser tallene i tabell 5.1 tydelig at de fleste av disse ordningene gjør det mulig for innbyggerne å involvere seg på flere ulike tidspunkter i den politiske syklusen og i alle de tre lederskapsfunksjonene. Gjennom de ordningene som er listet opp i tabellen, vil innbyggere kunne bidra til å sette dagsorden, til å utvikle løsninger på saker som allerede er satt på dagsordenen, og til å mobilisere ressurser for å implementere løsninger. Intervjuer med politikere viser imidlertid at ordningene i praksis brukes stort sett som høringsinstrumenter (Klausen et al., 2013, Vabo \& Winsvold, 2018). Videre viser intervjuer at politikerne er langt mer villige til å gi innbyggere innpass når det gjelder å foreslå mulige løsninger på problemer som allerede er satt på dagsordenen, enn når det gjelder å være med på å sette dagsorden (Vabo \& Winsvold, 2019).

Tabellen ovenfor gir et tidsbilde av hvilke typer ordninger som var utbredt i 2018. Bjerge (2019) har kartlagt hvilke deltakelsesordninger nye, sammenslåtte kommuner i Norge har vedtatt å innføre. Nye kommuner kan kanskje i særlig stor grad ha behov for tiltak som sikrer kontakt mellom politikerne og innbyggerne, fordi gamle kontaktmønstre blir brutt og endres når to eller flere enheter slår seg sammen til en ny og større enhet. Denne kartleggingen bærer uansett bud om hvordan man i kommuner i fremtiden ser for seg at man skal løse spenningen mellom innbyggerdeltakelse og politisk lederskap. I sin kartlegging skiller Bjerge mellom blant annet tiltak for deliberative ordninger, samstyring og deltakende budsjettering. Hun finner at de 35 nye kommunene som i 2019 var besluttet etablert som følge av kommunereformen (ut fra 91 opprinnelige kommuner), innførte til sammen 55 ulike tiltak for innbyggerdeltakelse. Den vanligste formen for tiltak er deliberative ordninger, som er vedtatt innført i 29 av de nye kommunene. Åtte av 35 kommuner hadde planlagt å innføre tiltak for samstyring, herunder oppgaveutvalg, som var planlagt i fire nye kommuner. I omtrent halvparten (14 av 35) av kommunene var 
det planlagt innført tiltak som har elementer av deltakende budsjettering i seg. I de fleste tilfellene dreier dette seg om nærmiljøutvalg som får overført noen ressurser som innbyggerne i et lokalområde kan disponere. Denne kartleggingen indikerer at mer omfattende innbyggerinvolvering kanskje er på vei i norske kommuner.

\section{Oppgaveutvalg: Politikere og innbyggere lager politikk sammen}

Etablering av oppgaveutvalg er et forsøk på nettopp å gi innbyggere større innflytelse, samtidig som de folkevalgte sikrer at de beholder den makten som er nødvendig for å kunne peile ut kursen for kommunen og initiere politisk endring. En slik ordning er, som vi har sett i kapittel 3, innført i blant annet den danske kommunen Gentofte og den tidligere norske kommunen Svelvik (nå del av nye Drammen kommune). Utvalgene oppnevnes av kommunestyret for en avgrenset tidsperiode, og de skal i løpet av denne perioden utarbeide forslag innenfor et bestemt politikkfelt. I oppgaveutvalgene sitter både valgte kommunestyrerepresentanter og innbyggere. Sammen med representanter for kommuneadministrasjonen møtes utvalgene med jevne mellomrom og diskuterer seg frem til forslag som det så voteres over i kommunestyret.

I teorien forener oppgaveutvalgene to forventninger. Forventningen om at innbyggerne i et demokrati skal styre seg selv, innfris fordi vanlige, menige innbyggere får være med på å utvikle politikk på et bestemt felt. Samtidig innfris forventningene til politisk lederskap gjennom representativt demokrati ved at de valgte politikerne beholder makten, både til å sette dagsorden (det er kommunestyret som definerer hvilke temaer som skal utredes av oppgaveutvalg) og til å fatte beslutninger (forslagene stemmes over og vedtas i kommunestyret). De folkevalgte har dermed både hodet og halen på prosessen og sikrer representativitet i begge ender.

Prinsipielt kan man innvende at verken selvstyre eller representativt styre realiseres fullt ut gjennom denne ordningen. Innbyggerne får ikke bestemme selv, de får bare komme med forslag, og representantene mister i praksis noe makt fordi det ligger makt i saksforberedelse og formulering av forslag: Den som bestemmer hvordan en sak skal rammes inn 
og presenteres, legger føringer for hvilke løsninger som virker rimelige å velge. Gjennom ordningen med oppgaveutvalg får dermed innbyggerne noe mer makt, men kanskje ikke særlig mye, og politikerne avgir noe makt, men kanskje ikke særlig mye. Evalueringer av ordningene (Sørensen \& Torfing, 2019b) viser imidlertid at politikere og innbyggere i praksis opplever i nokså liten grad at det er noen konflikt mellom elementet av direkte demokrati, som oppgaveutvalg tilfører, og det representative demokratiet. De fleste politikere ser på utvalgene som en berikelse. Spesielt trekker de frem at utvalgene gir bedre beslutningsgrunnlag, og at bedre forankring i befolkningen gjør iverksettingen av det som vedtas, lettere. Flere politikere opplever at samarbeidet med innbyggerne gir dem et mer nyansert syn på hvordan ulike løsninger fungerer. I noen sammenhenger mener politikerne også at de løsningene de kommer frem til i oppgaveutvalgene, er mer oppfinnsomme, presise og kreative enn de løsningene de tror de ville ha klart å komme frem til dersom det var politikerne alene som skulle utvikle dem.

Noen utfordringer er det likevel. Særlig i den norske kommunen Svelvik har politikerne vært opptatt av at de i oppgaveutvalgene ikke skal gå ut over det mandatet de har fått fra sine velgere. Selv om politikerne «legger fra seg hatten som partipolitiker» når de arbeider i oppgaveutvalgene, som en av politikerne uttrykker det, så er partiprogrammet førende for hvilke forslag de kan stille seg bak. En annen utfordring er at slikt samarbeid har som premiss at deltakerne skal klare å komme til enighet om et sett av løsninger (se kapittel 2). I tillegg til at man må klare å etablere et godt samarbeidsklima, så er det, ifølge politikerne i Svelvik, en forutsetning at det ikke er altfor stor politisk uenighet på det feltet man skal utarbeide forslag på. I den danske kommunen Gentofte er politikerne mer villige til å slippe innbyggere inn i politikkutviklingsprosesser, også der det er stor politisk uenighet. De har erfart at det å involvere innbyggere kan bidra til at en fastlåst prosess beveger seg videre, blant annet fordi politikerne angivelig «oppfører seg mer anstendig» med innbyggerne til stede. Tilbakevendende og symbolske uenigheter legges til side, og politikerne blir opptatt av å få dialog med både innbyggerne og hverandre. Enkelte politikere mener likevel at oppgaveutvalgene hindrer reelle politiske uenigheter i å komme til overflaten, og at det blir skapt en 
slags tvungen konsensus fordi politikere ikke helt tør å være uenige med innbyggerne i utvalget. Videre er noen som anser det som et problem at innbyggerne ikke får være med på å sette dagsorden, mens andre politikere vurderer akkurat det som en betingelse for at de skal våge å slippe innbyggerne så tett innpå politikkutviklingen. Dersom politikerne gir fra seg makten til å sette dagsorden, vil det kunne bli vanskelig å følge opp den kontrakten de opplever at de har inngått med velgerne sine på valgdagen.

Langt på vei ser det ut til at oppgaveutvalg faktisk inkluderer innbyggerne i politikkutformingen, men først og fremst når det gjelder å finne løsninger på problemer som allerede er satt på dagsordenen. Dagsordensetting holder politikerne for seg selv, både i Gentofte og Svelvik.

\section{Hvordan deltar folk mellom valg?}

Oppgaveutvalg er en formell kanal for medvirkning. Denne kanalen er initiert, etablert og driftet av kommunen. Deltakelse kan imidlertid også skje gjennom kanaler som ikke er etablert i regi av kommunen. Demonstrasjoner, underskriftskampanjer og aksjoner er eksempler på slike kanaler. Videre kan deltakelse skje ved at folk eller grupper tar kontakt med politikere på eget initiativ for å diskutere eller si ifra om noe.

Det er både fordeler og ulemper med formelle kanaler. En fordel med formelle kanaler er at innspill som kommer gjennom slike kanaler, oftere blir registrert, og at det dermed er synlig for alle hvilke innspill som påvirker en beslutning, samt hvem disse innspillene kommer fra. Dersom en innbygger helt uformelt stopper ordføreren på gaten i et forsøk på å påvirke, vil ikke dette forsøket på påvirkning registreres noe sted. Man kan tenke seg at ressurssterke aktører lett vil kunne påvirke uformelt og dermed få uforholdsmessig stor innflytelse. Uformell påvirkning har med andre ord større sannsynlighet for å skje i lukkede, ikke offentlige rom (se kapittel 4). Imidlertid er en ulempe med formelle tiltak at det er kommunen, og ikke folk selv, som har identifisert saken de vil ha innspill til, og kanskje er det ikke akkurat denne saken som ligger innbyggerne på hjertet. Engasjementet i egeninitiert deltakelse er derfor ofte mye sterkere, 
mens det kan være vanskelig å få folk til å stille opp når kommunen inviterer (Klausen et al., 2013).

Både formelle og uformelle kanaler for deltakelse kan likevel bidra til at styringen av samfunnet i større grad involverer innbyggere - hvor politikken ikke bare utøves av et smalt sjikt av valgte politikere, men hvor et bredere lag av befolkningen deltar i alle ledd i den politiske styringen, som i å sette dagsorden, i å finne løsninger og i å mobilisere ressurser. Det finnes ikke tall som viser hvor i den politiske prosessen folk deltar, men det finnes tall som viser hvilke kanaler folk deltar gjennom. Tabell 5.2 viser hvor stor andel av innbyggerne som oppga at de hadde deltatt på ulike måter for å påvirke kommunalpolitiske beslutninger. Slike tall samles inn etter hvert kommunevalg. Tallene i tabellen er fra 2015, men det har vært lite variasjon de siste 20 årene (Winsvold, Rose \& Klausen, 2017).

Tabell 5.2 Prosentandel av befolkningen som i løpet av de siste fire årene har gjort ulike aktiviteter for å påvirke beslutninger i kommunen de bor i. $\mathrm{N}=1340$.

Kilde: Winsvold, Rose \& Klausen 2017, s. 152-153.

\begin{tabular}{|l|r|}
\hline Form for deltakelse & Andel i prosent \\
\hline Skrevet under på opprop, underskriftskampanje & 33 \\
\hline Tatt kontakt med lokal politiker & 25 \\
\hline Deltatt i møte om en sak & 23 \\
\hline Tatt opp sak i parti, fagforening eller organisasjon & 17 \\
\hline Aksjon, protestmøte, demonstrasjon & 16 \\
\hline Skrevet i avisen, henvendt seg til media & 11 \\
\hline Vært til stede i kommunestyremøte & 10 \\
\hline
\end{tabular}

Noen av disse deltakelsesformene er åpenbart initiert av folk selv, mens andre også kan være initiert av kommunen. Det er verdt å merke seg at én av fem innbyggere oppgir at de har tatt kontakt med en lokal politiker for å påvirke beslutninger i løpet av de siste fire år. Denne tendensen speiler seg i politikernes rapporterte kontakt med innbyggerne. I Norge oppgir 67 prosent av politikerne at de minst ukentlig er i kontakt med innbyggere om politiske spørsmål. I Danmark er tallet enda høyere. Her oppgir 80 prosent at de minst ukentlig er i kontakt med innbyggere (Vabo \& Winsvold, 2019). 
Det har vært argumentert for at det viktigste med kanaler for innbyggermedvirkning ikke egentlig er at de brukes, men at de finnes og kan brukes dersom folk skulle oppleve det nødvendig (Hibbing \& Theiss-Morse, 2011). Et representativt demokrati innebærer jo faktisk at folk overlater til sine valgte representanter å fatte beslutninger. Hvis folk stoler på politikerne og mener at de gjør en god jobb med å representere dem, er det ikke sikkert at de vil ha behov for å komme med innspill eller protester. I det øyeblikket folk ikke lenger er fornøyd eller mener at politikken kunne ha blitt enda bedre, og dersom de har en idé for hvordan dette kan gjøres, er det imidlertid viktig at slike kanaler finnes og kan brukes. Kanaler for deltakelse kan dermed ses på som en slags sikkerhetsventil. Når de ikke blir brukt, kan det være et tegn på at folk er fornøyd, men det kan også være et tegn på at kanalen ikke er egnet. En forutsetning for at politikerne skal kunne tolke manglende engasjement som et tegn på tilfredshet, er at folk kjenner til mulighetene, og at kanalene er enkle å bruke - altså at terskelen er lav (Klausen et al., 2013).

\section{Er samskapt politikk mer demokratisk?}

Spørsmålet er så om tettere kontakt mellom politikere og innbyggere i politikkutviklingen gjør demokratiet mer demokratisk. For å kunne vurdere verdien av slikt samarbeid har ulike forfattere fremsatt forskjellige kriterier som må innfris for at politikkutvikling skal kunne sies å foregå på en demokratisk måte. Det kriteriet som oftest går igjen i litteraturen, er inklusjon (Rowe \& Frewer, 2004; Abelson \& Gauvin, 2006; Dalton, 2006; Papodopoulos \& Warin. 2007; Fung, 2008; Smith, 2009; Michels, 2011; Geissel, 2012). Deltakelsen må være inkluderende på den måten at stemmer fra alle samfunnslag og sosiale grupper blir hørt, og slik at ikke visse grupper blir marginalisert eller ekskludert. Andre viktige kriterier er at deltakelsen er meningsfull - altså at den handler om ting som er viktig for folk, at det å delta faktisk får betydning (Fung, 2008; Smith, 2009; Michels, 2011), og at folk har innsyn i hvordan beslutningsprosesser er organisert og i betingelsene for deltakelsen (Dalton, 2006; Geissel, 2012).

Valg innfrir disse kriteriene, men i hvilken grad gjør ulike former for innbyggerdeltakelse det? Undersøkelser av medvirkningstiltak i norske 
kommuner viser at disse noen ganger oppleves som lite meningsfulle og ugjennomsiktige, men at dette kan bøtes på ved at kommunen eller politikerne på forhånd tydeliggjør premissene for deltakelsen, altså hva folk kan forvente å ha innflytelse over, hvor mye innflytelse innspillene deres får, og hvordan innspillene behandles og brukes i beslutningsprosessen (Christensen et al., 2010; Klausen \& Arnesen et al., 2013; Vabo \& Winsvold, 2018). Innbyggerdeltakelse utenom valg har vært særlig kritisert for ikke å innfri kravet til inklusjon. Når innbyggere blir invitert til å være med på å utforme politikken innenfor et felt, så blir flere stemmer hørt enn dersom politikerne gjorde dette alene. Men hvilke stemmer blir hørt? Den representative styringskjeden har den fordelen at alle stemmer teller likt når kandidater skal utpekes. Ved deltakelse i politikkutforming er det derimot bare de som deltar, som får innflytelse. Sikrer så deltakelse utenom valgkanalen at «folket» får være med på å styre? Og bidrar denne formen for involvering av innbyggere til at politikken blir mer demokratisk?

Kort fortalt sikrer deltakelse utenom valgkanalen bredere folkelig styring i den forstand at en større del av «folket» og flere av folks synspunkter legges til grunn for politiske vurderinger og vedtak. Mer representativ blir styringen imidlertid ikke. For det første er de som allerede er knyttet til et bestemt parti, svært overrepresentert i deltakelse, også mellom valg. Det er altså de som allerede er politisk aktive på en eller annen måte, som i størst grad deltar i politikkutforming utenom valg. For det andre er slik deltakelse - også når man ser bort fra partimedlemskap - sterkt knyttet til utdanning. De med høy utdanning deltar altså mer enn de med lav utdanning (Winsvold et al., 2017). Det betyr at innbyggere med lav utdanning og uten partitilknytning er underrepresentert i deltakelse mellom valg. Det er akkurat den samme skjevheten i representasjon som vi finner ved valg. Dermed bidrar deltakelsen utenom valg til å gjøre representasjonen enda skjevere, fordi den gir dem som allerede deltar, ytterligere muligheter til å påvirke.

Bildet er imidlertid mer nyansert. For det første blir tilfanget av folk som deltar utenom valg, påvirket av hvordan innbyggere blir rekruttert til slik deltakelse. Skjevest blir deltakelsen når deltakerne er fullt ut selvrekruttert, altså når det er fritt frem for hvem som helst å delta, og når kommunen ikke gjør noen forsøk på å nå bestemte grupper. Deltakelsen 
kan bli mindre skjev dersom kommunen bestreber seg på å nå grupper som man ellers ofte ikke får i tale, eller grupper som er særlig berørt. Hvem man ønsker å rekruttere, kan man ta stilling til i kommunen, og man kan velge å prioritere dem man ellers ikke ville ha hørt fra.

For det andre kan folk - på samme måte som politikere - representere flere og andre enn seg selv. I ideen om bred deltakelse ligger det en antakelse om at folk som deltar i politikkutforming uten å være valgt inn i kommunestyret, gjør det fordi de selv er berørt, og fordi de vil bidra med sitt perspektiv. Når vi ved hjelp av innbyggerundersøkelser måler hva som kjennetegner dem som deltar politisk utenom valg, så ser vi at de ofte er ressurssterke, godt voksne mennesker som allerede er politisk aktive. Dette er altså akkurat den samme gjengen som de som sitter i kommunestyret. Men i mange sammenhenger møter ikke disse innbyggerne opp kun på egne vegne. De kommer på vegne av noen andre, og gjerne på vegne av en gruppe mennesker som har liten mulighet til å representere seg selv, på vegne av bygda de bor $\mathrm{i}$, som FAU-representant på vegne av foreldrene på skolen, som foreldre på vegne av funksjonshemmede barn, eller som barn på vegne av pleietrengende foreldre. Slik sett blir innbyggere som deltar i politikkutforming mellom valg, gjerne også representanter, selv om de ikke er valgt og ikke kan avsettes på samme måte som de folkevalgte politikerne kan. Innbyggere som deltar mellom valg, opptrer altså ofte som representanter for en bestemt gruppe, og dermed blir representasjonen mindre skjev enn den kan se ut på overflaten: Den 50 år gamle høyt utdannede mannen som avtegner seg i statistikken som den gjennomsnittlige deltakeren, er også far til en funksjonshemmet tenåring, ishockeyentusiast og sønn til en pleietrengende far. Gjennom ham blir dermed interessene til disse innbyggerne - eventuelt gruppene av innbyggere - representert.

\section{Kan spenningen mellom representasjon og deltakelse løses?}

Som dette kapitlet viser, utsettes lokale folkevalgte for kryssende forventninger. På den ene siden forventes de folkevalgte å innfri den representative styringskjedens krav til å forvalte mandatet de har fått ved valg, som 
innebærer å være tro mot partiprogrammet de er valgt inn på. På den andre siden forventes de å lytte til innbyggerne mellom valg og potensielt fravike mandatet som partiprogrammet ga, dersom de vurderer det som riktig. Folket skal styre seg selv, men de har samtidig bedt politikerne om å styre på deres vegne. Politikerrollen innebærer å håndtere denne balansen mellom å styre på bakgrunn av et mandat og å lytte og justere egne standpunkter etter det som sies. I noen tilfeller blir denne balansegangen umulig. En politiker som er valgt inn for å representere en liste som slåss for å opprettholde grendeskolen, og som så, etter samtale med skolens ansatte, kanskje opplever det som mest riktig å legge ned skolen likevel, vil ikke kunne innfri begge forventninger samtidig. I slike tilfeller må den enkelte representanten velge om hun vil utøve mandatet hun fikk av velgerne og stemme for å bevare skolen, eller om hun vil lytte til de ansatte og dermed bryte løftet som ble gitt på valgdagen. Hvilken av disse to handlingene vil i størst grad samsvare med å «la folket styre seg selv»? Hva er mest demokratisk? Dette finnes det ingen enkle svar på.

Konflikten mellom det å skulle styre på folkets vegne samtidig som man skal lede, blir satt på spissen når de folkevalgte er uenige med innbyggerne om hva som er den beste løsningen. Kommunesammenslåingsprosessen, som ble igangsatt under Solberg-regjeringen i 2014, ga eksempler på dette. I flere kommuner ønsket politikerne en sammenslåing, men innbyggerne sa nei i folkeavstemning. I de fleste tilfeller valgte politikerne å la folket styre seg selv. De lyttet til hva folk sa og lot dem bestemme. I denne saken fikk det å lytte til folkeavstemningsresultatet presedens (Folkestad et al., 2019), men i mange andre og kanskje mindre saker er det ikke slik. Avveiningen mellom å lytte til innbyggerne og å lede kommer også ofte til syne i nedleggingssaker. Nedlegging skjer gjerne som en konsekvens av økonomisk nødvendighet, og de som berøres, er sterkt imot, mens de som ikke berøres, er likegyldige. I slike tilfeller, når utfallet av en sak er gitt på forhånd, kan det være ekstra vanskelig å skulle lytte.

Det å styre på folks vegne kan altså innebære å ta det folk ønsker, til følge, eller å gjøre egne vurderinger av hva som gagner folket best på lang sikt. Folkevalgte vekter de to hensynene ulikt, men de fleste gjør begge typer vurderinger $\mathrm{i}$ alle saker som de fatter beslutning i. I ordførerintervjuet som følger etter dette kapitlet, skal vi se hvordan politikerne i 
Nedre Eiker vektet folkets mening mot det de oppfattet som en økonomisk nødvendighet.

Når det er sagt, så er det ikke sikkert at det samtidig å skulle lytte og å skulle lede alltid trenger å være så vanskelig. Politikere vi har intervjuet oppgir at de i de fleste saker synes det er lett å styre etter sitt partipolitiske kompass, og innspill folk kommer med, endrer ikke kursen radikalt, men kan bidra til å justere den. Videre er det som oftest ingen stor motsetning mellom det politikere mener og det folk mener. Folkevalgte er jo også folk. De er bosatt i kommunen, de har familie, venner og kanskje jobb i nærmiljøet, og de er stort sett bredt orientert om hva som rører seg i kommunen. Vi har, som velgere, gitt dem tillit og pekt dem ut til å fatte beslutninger på våre vegne, nettopp fordi vi tror at de kan representere våre interesser på en god måte, noe de fleste politikere kan. Folkevalgte har likevel mye å lære, fordi det med nødvendighet ligger mer kunnskap og flere ideer i befolkningen som helhet, enn i kommunestyresalen eller i kommunens administrasjon. De fleste politikere vet dette, og de er stadig på jakt etter å få vite hva folk mener og tenker om hvordan kommunepolitikken kan gjøres bedre.

\section{Referanser}

Aarts, K., Thomassen, J. \& van Ham, C. (2014). Globalization, representation, and attitudes towards democracy. I J. Thomassen (Red.), Elections and democracy: representation and accountability, (s. 201-231). Oxford, England: Oxford University Press.

Abelson, J. \& Gauvin, F.-P. (2006). Assessing the impacts of public participation: Concepts, evidence and policy implications. Research Report Po6. Salt Lake City, UT: Canadian Policy Research Network.

Ansell, C. \& Torfing, J. (2017). Strengthening political leadership and policy innovation through the expansion of collaborative forms of governance. Public Management Review, 19(1), 37-54.

Beetham, D. (Red.). (2006). Parliament and democracy in the twenty-first century: A guide to good practice. Genève, Sveits: Inter-Parliamentary Union.

Bjerge, N. (2019). Demokratiske innovasjoner i kommune-Norge: bidrag til et sterkere lokaldemokrati? Masteroppgave i statsvitenskap. Oslo: Institutt for statsvitenskap, Universitetet i Oslo.

Christensen, D. A., Sandkjær Hanssen, G., Kittelsen, E., Klausen, J. E., Winswold, M. \& Aars, J. (2010). Evaluering av innbyggerinitiativordningen. Samarbeidsrapport NIBR/Rokkansenteret. Tilgjengelig via https://www.regjeringen.no 
Dalton, R. J. (1985). Political parties and political representation: Party supporters and party elites in nine nations. Comparative Political Studies, 18(3), 267-299.

Dalton, J. R. (2006). Citizenship norms and political participation in America: The good news is ... the bad news is wrong. CDACS Occasional Paper 2006-01.

Folkestad, B., Klausen, J. E., Saglie, J.o \& Segaard, S. B. (2019). When do consultative referendums improve democracy? Evidence from local referendums in Norway. International Political Science Review. https://doi.org/10.1177/0192512119881810

Fung, A. (2008). Democratizing the policy process. I R. Goodin, M. Moran \& M. Rein (Red.), The Oxford handbook of public policy. Oxford, England: Oxford University Press. https://doi.org/10.1093/oxfordhb/9780199548453.003.0033

Geissel, B. (2012). Impacts of democratic innovation in Europe. Findings and desiderata. I B. Geissel \& K. Newton (Red.), Evaluating democratic innnovations. Curing the democratic malaise? New York: Routledge.

Hibbing, J. R. \& Theiss-Morse, E. (2011). Stealth democracy. Americans' beliefs about how government should work. Cambridge, England: Cambridge University Press.

Inndelingslova. (2002). Lov om fastsetjing og endring av kommune- og fylkesgrenser. (LOV-2019-06-21-35). Hentet fra https://lovdata.no/dokument/NL/ lov/2001-06-15-70?q=inndelingsloven

Kane, J. \& Patapan, H. (2012). The Democratic leader: How democracy defines, empowers and limits its leaders. Oxford, England: Oxford University Press.

Karsten, N. \& Hendriks, F. (2017). Don't call me a leader, but I am one: The Dutch mayor and the tradition of bridging-and-bonding leadership in consensus democracies. Leadership, 13(2), 154-172.

Klausen, J. E., Arnesen, A., Christensen, D. A., Folkestad, B., Hanssen, G. S., Winsvold, M. \& Aars, J. (2013). Medvirkning med virkning? Innbyggermedvirkning i den kommunale beslutningsprosessen. Oslo: Norsk institutt for by- og regionforskning / Uni Rokkansenteret.

Kommuneloven. (2019). Lov om kommuner og fylkeskommuner. (LOV-2019o6-21-57). Hentet fra https://lovdata.no/dokument/NL/lov/2018-o6-2283 ? q=kommuneloven

Michels, A. (2011). Innovations in democratic governance: how does citizen participation contribute to a better democracy? International Review of Administrative Sciences, 77(2) 275-293.

Monkerud, Lars Chr.; Indset, Marthe; Stokstad, Sigrid; Klausen, Jan Erling (2016). Kommunal organisering 2016 - Redegjørelse for Kommunal- og moderniseringsdepartementets organisasjonsdatabase. ISBN: 978-82-8309-134-2.

Neblo, M. A., Esterling, K. M., \& Lazer, D. M. (2018). Politics with the people: Building a directly representative democracy. Cambridge: Cambridge University Press. 
Papadopoulos, Y. \& Warin, P. (2007). Are innovative, participatory and deliberative procedures in policy making democratic and effective? European Journal of Political Research, 46(4), 445-472.

Plan- og bygningsloven. (2008). Lov om planlegging og byggesaksbehandling. (LOV2008-06-27-71). Hentet fra https://lovdata.no/dokument/NL/lov/2008-06-27-71.

Rowe, G. \& Frewer, L. J. (2004). Evaluating public-participation exercises: A research agenda. Science, Technology \& Human Values, 29(4), 512-556.

Smith, G. (2009). Democratic innovations: designing institutions for citizen participation. Cambridge: Cambridge University Press.

Stigen, I. M., Kolltveit, K. \& Winsvold, M. (2018). Fra valg til velferd. Innføring $i$ statsog kommunalkunnskap. Oslo: Cappelen Damm Akademisk.

Stoker, G. (2019). Can the governance paradigm survive the rise of populism? Policy \& Politics, 47(1), 3-18.

Sørensen, E. \& Torfing, J. (2019a). Towards robust hybrid democracy in Scandinavian municipalities? Scandinavian Political Studies, 42 (1), 25-49.

Sørensen, E. \& Torfing, J. (2019b). Slutevaluering af forsøg med opgaveudvalg i Svelvik kommune. Hentet 12. desember 2019 fra https://www.svelvik.kommune.no/ contentassets/2774bc5aoodd48fiagfid 36 c9oo5eaa1/evaluering-oppgaveutvalgsvelvik-kommune.pdf

Tucker, R. C. (1995). Politics as leadership. Columbia, MO: University of Missouri Press. Vabo, S. I. \& Winsvold, M. S. (2018). Designing institutions for interactive political leadership in local governments - possibilities and contingencies. ECPR General Conference. European Consortium for Political Research, Hamburg, August 22nd to 25 th 2018

Vabo, S. I. \& Winsvold, M. S. (2019). Interactive governance arrangement and political leadership in context. Analysing the relevance of political-administrative system. Paper presentert på Phd-course STV9430A - Political leadership and democratic innovations in local governments, workshop ved Centre Universitaire de Norvège à Paris (CUNP), 7.-9. oktober 2019.

Winsvold, M. S. (2019). Kvinner og menn i kommunepolitikken - hvem mener de at de representerer og hvor stor innflytelse opplever de å ha? Tidsskrift for kjønnsforskning, 43(3), 177-197.

Winsvold, M. S., Rose, L. \& Klausen, J. E. (2017). Politisk deltakelse mellom valg. I J. Saglie \& D. A. Christensen, Lokalvalget 2015 - et valg i kommunereformens tegn? Oslo: Abstrakt forlag.

Winsvold, M. S., Nørve, S. Winsvold, M. S. (2019). Kvinner og menn i kommunepolitikken - hvem mener de at de representerer og hvor stor innflytelse opplever de å ha? Tidsskrift for kjønnsforskning, S. \& Vestby, G.-M. (2014). Råd, regler og representasjon. Eldre og mennesker med nedsatt funksjonsevne. NIBRrapport 2014: 4. Oslo: Norsk institutt for by- og regionforskning. 


\section{Gikk imot folkeavstemning}

Tekst: Marte Winsvold. Intervju foretatt 16. oktober 2019.

Innbyggerne i Nedre Eiker stemte nei til kommunesammenslàing, men kommunestyret besluttet likevel at kommunen skulle bli en del av nye Drammen fra 1. januar 2020. I dette intervjuet forklarer tidligere ordfører Bent Inge Bye hvorfor.

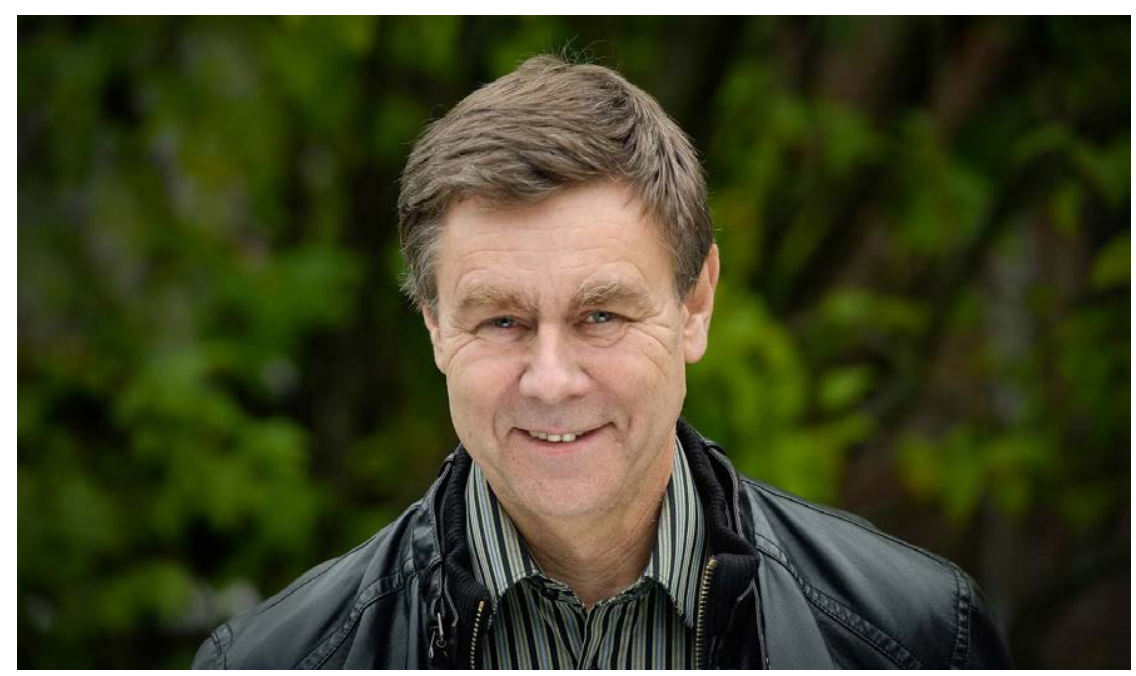

FOLKEAVSTEMNING: «Er et så komplisert spørsmål som kommunesammenslåing egnet for en folkeavstemning? Jeg er veldig usikker», sier tidligere ordfører i Nedre Eiker, Bent Inge Bye. (Foto: Torbjørn Tandberg. Bildet er gjengitt med tillatelse og omfattes ikke av bokens lisens.)

Da Nedre Eiker skulle utrede muligheten for kommunesammenslåing, gjennomførte kommunen en innbyggerundersøkelse som viste at 54 prosent av innbyggerne var for sammenslåing. Siden flertallet for sammenslåing var så knapt, bestemte kommunestyret at de skulle legge spørsmålet ut til folkeavstemning for å få et bedre grunnlag å fatte beslutning på. «Resultatet av folkeavstemningen ble at 55 prosent sa nei, og 44 prosent sa 
ja, så det var ganske 'close'», forteller Bye, «men valgdeltakelsen var veldig lav, på bare 30 prosent. Da kan man spørre seg, og det var det mange som gjorde: 'Er dette egentlig et uttrykk for innbyggernes vilje?'».

\section{Folkevilje eller valgløfter}

Nedre Eiker har i mange år slitt med dårlig økonomi og sto på ROBEKlisten, og slik ordføreren oppfattet situasjonen, kom politikerne i Nedre Eiker i et dilemma. De valgte å si ja til sammenslåing for at de skulle klare å innfri valgløftene de hadde gitt innbyggerne:

«I Nedre Eiker, som i alle andre kommuner, legger de politiske partiene frem valgprogram når de går til valg, og det er jo førende for hvilke løfter du må prøve å innfri overfor innbyggerne», sier Bye. «For vårt vedkommende så var et av de viktigste momentene nytt sykehjem. Det har stått på agendaen for de politiske partiene gjennom flere valg, men vi har ikke klart å realisere det fordi vi har hatt så anstrengt økonomi.»

Da folkeavstemningen ga et nei-flertall, ba kommunestyret rådmannen om å se på hvordan Nedre Eiker kunne klare å finansiere de nødvendige investeringene, blant annet nytt sykehjem, dersom de ble stående alene. Nedre Eiker hadde ikke egenkapital å skyte inn i investeringer. Alle tunge investeringer måtte lånefinansieres 100 prosent, og fordi kommunen sto $\mathrm{i}$ ROBEK-registeret på den tiden, hadde den ikke anledning til å ta opp lån. Stortinget endret dessuten kriteriene for beregning av rammetilskuddet til kommunene. Da statsbudsjettet for 2016 ble lagt frem, viste det seg at endringene slo negativt ut for Nedre Eiker. Den beregnede veksten i frie inntekter dekket ikke opp for den beregnede lønns- og prisutviklingen. «Rådmannens svar var at eneste mulighet for å gi velgerne det vi hadde lovet, var å innføre eiendomsskatt og å skyte ut tunge investeringer, blant annet nytt sykehjem. Dette sa de politiske partiene nei til. Så hva skulle vi gjøre da?» spør Bye.

Han beskriver det som en umulig situasjon. «Vi sto med valget mellom å gå inn i en ny kommune, mot innbyggernes vilje - slik den ble uttrykt i folkeavstemningen - og ikke å ta på oss de forpliktelsene som vi hadde lovet innbyggerne, og som det var stort behov for.» 
I denne situasjonen var det nødvendig å ta politisk lederskap, mener Bye. «Du må på ett eller annet tidspunkt ta ansvar. Du kan ikke skyve problemet foran deg - ikke når du sitter og skal styre en kommune, for problemene bare hoper seg opp, og den bølgen du har skjøvet foran deg, den får du over deg, for problemene forsvinner ikke. Sykehjem var et påtrengende behov, men den eneste måten å realisere det på var ved å slå seg sammen eller å innføre eiendomsskatt. Du kan ikke si til folk som ikke får sykehjemsplass, at dessverre, du får ikke sykehjemsplass, men du bor fortsatt i din egen kommune. Det hjelper ikke om du er aldri så glad i kommunen dersom du ikke kan gi den velferden til innbyggerne som de trenger.»

\section{Folkeavstemning egnet?}

Bye synes likevel at det å gå imot resultatet av folkeavstemningen var et vanskelig valg å ta. Han var også selv i utgangspunktet imot sammenslåing.

«I Nedre Eiker, som i de fleste andre kommuner, er det stor grad av patriotisme. Folk er jo glad i kommunen sin. Den patriotismen og den kjærligheten folk har til kommunen, stilt opp mot de økonomiske realitetene, det er det som er vanskelig. Men når den økonomiske realiteten var at vi ikke klarte å innfri de valgløftene vi hadde gitt, så sier noen at du må vise politisk lederskap. Andre sier at du er en sviker», forteller han.

I Nedre Eiker har de i ettertid diskutert hvorvidt folkeavstemning er en god måte å høre folket på. «Dette handler jo om følelser opp mot økonomi», sier Bye, «og folk setter seg jo ikke ned og ser på det økonomiske grunnlaget og hvordan vi skal finansiere velferden vår. Spørsmålet er så omfattende og har så store konsekvenser på mange forskjellige områder. Er et så komplisert spørsmål som kommunesammenslåing egnet for en folkeavstemning? Jeg er veldig usikker. Og det gjelder ikke bare kommunesammenslåing. Du gir jo politikere et mandat gjennom valg og så får du da stole på at de gjør det som velgerne har stemt dem fram for. De fleste velgere leser valgprogrammene og har tillit til enkeltpersoner, men skal du gå bort fra det og si at man skal ha avstemninger for å se hva velgere mener om enkeltsaker? Jeg er i tvil om det er riktig», sier han. 
Den tidligere ordføreren tror det er blitt vanskeligere å være politiker fordi sosiale medier bygger opinion rundt enkeltsaker:

«Det øves veldig stort press på politikere i perioden. Så det å få manøvrert i det politiske landskapet, det er blitt mye vanskeligere. Nå opplever du at det bygges opp pressgrupper, og jeg må si at det har ikke bare vært hyggelig å være politiker etter at vi fattet vedtak om sammenslåing. Du blir stemplet, og det går i retning av trakassering. Man blir kalt for sviker og judas når man er ute og handler», forteller han og fortsetter: «Det er klart at man skjønner at folk mobiliserer mot sammenslåing, fordi det ligger så mye følelser i dette - hvilken kommune man hører til i. Og uansett hvordan vi hadde gått frem, folkeavstemning eller ikke, så ville det blitt bråk. Men jeg tror nok at mange politikere føler presset, og noen sier at dette orker de ikke mer.»

\section{Engasjere folk på nye måter}

Bye har vært involvert i nye Drammen som leder av fellesnemnda, og der har de jobbet med å få til møtefora og møteplasser ute i den nye storkommunen. Nye Drammen er delt inn i ti deler, og i hver av delene skal det være et nærmiljøutvalg der det skal sitte fire politikere, fire representanter fra valgte organisasjoner i området og fire innbyggere som velges på allmøte. Nærmiljøutvalgene skal gi tilbakemeldinger og være lytteposter ute i nærmiljøet. De fire politikerne skal være representanter for de ulike hovedutvalgene, og tanken er at de dermed vil kunne svare på spørsmål og formidle politikk om hvert sitt felt, og at de vil kunne bringe innspill fra nærområdene tilbake til kommunestyret.

Bye mener politikerne må ta inn over seg at partienes rolle er endret, og at mindre engasjement kanaliseres gjennom de politiske partiene. Han sier det slik:

«I Arbeiderpartiet, som jeg representerer ... dersom det var holdninger ute i bygda, så kom de til uttrykk i representantskapet. I mine yngre dager var det stort fremmøte og engasjement på partimøtene. Vi hadde aktive arbeiderlag i flere deler av kommunen. Jeg tror vi bare må innse at partienes rolle ikke er hva den var. I dag har vi ett lag i Nedre Eiker, og det 
er ikke bare oss, oppslutningen er mye svakere om de politiske partiene generelt. Partiene har ikke den vitaliteten de en gang hadde, og rekrutteringsbasen er annerledes og mye vanskeligere enn tidligere. Så man må tenke helt annerledes. Det er en utfordring for lokaldemokratiet. 
KAPITTEL 6

\title{
Refleksjoner rundt paradokser, lederskap og læring
}

\author{
Asbjørn Røiseland \\ Nord universitet, OsloMet - storbyuniversitetet
}

Eva Sørensen

Roskilde universitet

Jacob Torfing

Roskilde universitet

\begin{abstract}
In this chapter we sum up and conclude the book. In the first part we summarize the four paradoxes that have structured the book. The four paradoxes relate to conflict, administration, openness and democracy. We then discuss the national Norwegian framework for local government, and to what extent and how changes in for example national legislation can influence on the paradoxes and the tensions related to them. The third and last section focusses on the local level, and discusses how political leaders, individually as well as a collective, can strengthen their political leadership through different activities at different arenas for learning. In a brief and subsequent chapter, we give a practical example on how this may be organized.
\end{abstract}

Keywords: political leadership, local government, learning

\section{Introduksjon}

Gjennom å være valgt av folket i demokratiske valg er de folkevalgte formelle lederskikkelser i politikkens verden. Men mange folkevalgte opplever seg ikke nødvendigvis som politiske ledere, og de opplever heller ikke at de lykkes med å utøve sitt politiske lederskap, i betydningen at de faktisk bidrar til å løse lokalsamfunnets problemer og utfordringer.

Sitering av denne artikkelen: Røiseland, A., Sørsensen, E. \& Torfing, J. (2020). Refleksjoner rundt paradokser, lederskap og læring. I A. Røiseland \& S. I. Vabo (Red.), Folkevalgt og politisk leder (Kap. 6, s. 146-176). Oslo: Cappelen Damm Akademisk. https://doi.org/10.23865/noasp.8o.ch6 Lisens: CC BY-ND 4.0. 
Som vi har sett i kapitlene foran, påvirkes det lokale politiske lederskapet i kommunene av nasjonale rammebetingelser, samtidig som det varierer fra kommune til kommune og fra person til person, på tross av at de formelle rammebetingelsene er omtrent de samme. Dette kan tolkes som et uttrykk for at det å være valgt, ikke i seg selv er noen garanti for å bli en vellykket politisk leder.

Denne boken har vært organisert rundt fire paradokser knyttet til politisk lederskap som vi kan observere i norsk lokalpolitikk. Disse paradoksene er etter vår oppfatning nyttige innganger til å diskutere politisk lederskap og hvordan det kan utvikles videre. Det finnes ingen entydig oppskrift eller standard for hvordan politisk lederskap skal utøves. Først og fremst handler utvikling av politisk lederskap om refleksjon og diskusjon blant aktørene selv, det vil si blant folkevalgte politikere. Hensikten med dette kapitlet er først å summere opp bokens innhold samt å diskutere hvordan de fire paradoksene henger sammen. Deretter diskuterer vi i hvilken grad og på hvilken måte de fire paradoksene viser til endringsbehov når det gjelder nasjonale rammebetingelser for lokalt politisk lederskap i Norge. Denne diskusjonen handler om de formelle rammene for kommunal virksomhet og lokalt politisk lederskap, men vi vil også peke på betydningen av uformelle rammebetingelser i form av forestillinger om og holdninger til politisk lederskap.

Politisk lederskap er imidlertid ikke bare et spørsmål om ytre rammebetingelser. Det handler også om lokal bevisstgjøring, tilrettelegging og hvordan folkevalgte velger å fylle sine verv. I kapitlets tredje del diskuterer vi hvilke lokale læringsarenaer som står til disposisjon for norske lokalpolitikere, og hvordan et kommunestyre kan angripe behovet for å utvikle det lokalpolitiske lederskapet.

\section{Fire paradokser}

I innledningskapitlet forklarte vi ordet "paradoks» som noe fornuftstridig, som ved nærmere ettertanke likevel viser seg å inneholde en viss sannhet. For eksempel kan det tenkes at det som i første omgang ser ut til å stride mot fornuften, egentlig viser seg å representere en verdikonflikt 
eller en spenning mellom ulike hensyn, og at det derfor ikke er så uventet og fornuftstridig likevel. De forutgående kapitlene har alle hatt som siktemål å forklare de fire omtalte paradoksene gjennom å utforske hvorfor ting fremstår som de gjør. I det følgende skal vi kort oppsummere hvert av de fire paradoksene.

«Konfliktparadokset» tok utgangspunkt i den enkle observasjonen som viste at mens de fleste norske kommuner styres etter en konsensusorientert formannskapsmodell, så preges norsk kommunepolitikk i stor grad av konflikt mellom politiske grupperinger og partier. I kapittel 2 ble dette paradokset forklart gjennom å vise til at et demokratisk system fundert på representasjon, valgkamp og valg, forutsetter synliggjøring av interessekonflikter. Derfor er det ikke så rart at formannskapsmodellen i praksis fylles med konflikt, selv om modellen som sådan ikke er tilrettelagt for dette. Det som likevel fremstår som en utfordring for lokale politiske ledere, er å finne en god balanse mellom konflikt og konsensus. Kapittel 2 ga flere eksempler på kommuner som tilsynelatende har funnet denne balansen, og på kommuner som ikke har lykkes med å balansere de to hensynene på en konstruktiv måte.

«Administrasjonsparadokset» handlet helt enkelt om at mens politiske ledere i et demokrati er forventet å være involvert i alle prosesser med relevans for offentlig politikk, så er norske kommunepolitikere i stor grad henvist til å ta stilling til forslag og utredninger som en eksperttung administrasjon har stått bak. Norske kommunepolitikere er med andre ord lite involvert i de delene av politikkutformingsprosessen der problemer forstås, defineres og utredes, og der alternative løsninger blir formulert. I utforskningen av administrasjonsparadokset ble det i kapittel 3 pekt på at det tydelige skillet mellom administrasjon og politikk som vi finner i norske kommuner, og som er opphavet til paradokset, var en villet og bevisst politikk fra Stortingets side da kommuneloven gjennomgikk en omfattende revisjon tidlig på 1990-tallet. En viktig bakgrunn var behovet for å legge til rette for en mer profesjonalisert og tydeligere administrativ ledelse. Ideen om at politikk og administrasjon skulle skilles tydelig fra hverandre, ble ytterligere forsterket gjennom KS sin visualisering av prinsippet i form av den såkalte timeglassmodellen. I kapittel 3 viste vi at administrasjonsparadokset følger av de lovmessige rammene for norske 
kommuner, og at Norge her har valgt en annen modell enn Danmark, der ordføreren også innehar mange av de funksjonene som den norske kommunedirektøren (rådmannen) har. Men kapitlet viste også at selv om det norske systemet bygger på overordnede ideer om et tydelig skille mellom politikk og administrasjon, preges norske kommuner i det daglige av en mer pragmatisk tilnærming, spesielt når det gjelder forholdet mellom ordfører og kommunedirektør. Kapitlet viste også at ulike kommuner har ulike måter å forholde seg til skillet mellom politikk og administrasjon på, og at det, innenfor rammen av nasjonal lovgivning, finnes spillerom for lokale tilpasninger.

«Åpenhetsparadokset» tok utgangspunkt i det norske kravet om møteoffentlighet i alle kommunale politiske organer, og det handlet om en motsetning mellom disse reglene og det faktiske resultatet av dem. Mer konkret ble det i kapittel 4 argumentert for at de norske reglene for møteoffentlighet ikke nødvendigvis leder til mer åpenhet, men snarere til at de innledende diskusjonene av en sak - som vi omtalte som «arbeidsmøter» - forsvinner ut av det formelle styringssystemet og inn i partimøter og gruppemøter. Åpenhet er en åpenbar og viktig demokratisk verdi, men som vi var inne på i kapittel 4, så kan også motsatsen - lukkede prosesser og møter - iblant være forsvarlig og viktig, også i et demokrati. Dette innebærer at ethvert demokratisk system trenger å finne en rimelig balanse mellom åpenhet og lukkethet. Konkret, når det gjelder møteoffentlighet, har Norge valgt en radikal løsning der alle kommunale politiske møter er åpne for offentligheten, mens Danmark og mange andre land har valgt å lukke utvalgs- og komitémøter. Analysen i kapitel 4 viste at ulike regler om møteoffentlighet i Norge og Danmark har betydelige konsekvenser for den politiske prosessen, og at den norske modellen har en kostnad ved at det ikke finnes noen formell arena der et samlet kommunestyre, en komité eller et utvalg kan lufte halvtenkte ideer og innspill. Dette må i stedet skje i partienes gruppemøter der bare partiets egne politikere deltar. I praksis innebærer dette at store deler av den politiske diskusjonen i Norge ikke foregår innenfor det formelle politiske systemet, men på utsiden. Det kan være problematisk av flere grunner. For det første innebærer det at norske kommuner er mindre åpne enn det kommuneloven skulle tilsi. For det andre innebærer det at den innledende politiske 
diskusjonen, hvor politikerne leter seg frem til et standpunkt, skjer blant likesinnede i partienes gruppemøter. De folkevalgte får dermed ikke presentert hele bredden av argumenter for og imot en sak før de selv må lande på en konklusjon. Og endelig kan åpenhetskravet innebære at det blir vanskeligere for administrasjonen å involvere politikerne på et tidlig tidspunkt i en saksprosess.

Det siste paradokset, «demokratiparadokset», ble diskutert i kapittel 5 . Paradokset handler om at vi på den ene siden har ideer om at et demokrati gir innbyggerne frihet og like muligheter tilå influere på beslutninger som påvirker deres liv og velferd. Men samtidig praktiseres dette demokratiet gjennom et representativt system der noen få og utvalgte politikere gis fullmakt innenfor valgperioden til å handle på vegne av innbyggerne. Paradokset reiser spørsmålet om hvordan vi kan balansere hensynet til det suverene folk med ideer om politisk lederskap og politisk representasjon. I kapittel 5 angrep vi problemstillingen gjennom å argumentere for at både representasjon og direkte deltakelse lever side om side i norske og danske kommuner, og at det er utviklet en rekke ordninger med dette for øyet. Vi gjennomgikk noen viktige typer ordninger for direkte deltakelse, både de som kan sies å være en del av det representative systemet (for eksempel høringer), de som eksisterer som en motpol til representasjon (for eksempel opprop og underskriftskampanjer), og de som eksplisitt knytter direkte deltakelse og representasjon sammen (for eksempel gjennom å etablere arenaer hvor valgte politikere utvikler politikk sammen med innbyggerne). Direkte deltakelse representerer en høyverdig verdi for mange, men fra et normativt demokratiteoretisk synspunkt kan vi i utgangspunktet ikke slutte at direkte deltakelse er mer demokratisk enn representasjon gjennom valgte politikere. Vurderingen vil måtte bygge på kunnskap om hvem som deltar, og om hvilke samfunnsgrupper som får en styrket eller svekket posisjon som følge av direkte deltakelse versus representasjon. Dette innebærer også at når direkte deltakelse leder til konklusjoner som står i konflikt med konklusjonen blant flertallet av de valgte representantene, er det ikke gitt hvem som, i demokratiets navn, bør vinne frem.

De fire paradoksene har så langt vært diskutert hver for seg. Det har vært et bevisst valg for å få frem essensen i hvert enkelt. Men samtidig 
kan paradoksene henge sammen på forskjellige måter. Den mest åpenbare sammenhengen er forholdet mellom konflikt- og åpenhetsparadokset. Generell møteoffentlighet i norske kommuner inviterer politikerne til å bruke alle formelle møter til å markere sitt partis posisjoner fremfor å søke konsensus og kompromiss med politikere fra andre partier. At danske kommunepolitikere har en sterkere konsensusorientering enn de norske, kan slik sett skyldes (i alle fall delvis) forskjellen i reglene for møteoffentlighet i de to landene. Det kan også tenkes å være en sammenheng mellom åpenhetsparadokset og administrasjonsparadokset. Manglende muligheter for at politikerne kan drøfte en uferdig sak i fortrolighet, kan føre til at administrasjonen ikke gis mulighet til å involvere politikerne i en tidlig fase av saksbehandlingen, noe som igjen er med på å redusere de folkevalgte til rene beslutningstakere, henvist til administrasjonens saksutredninger og innstillinger.

\section{Utvikling av lokalpolitisk lederskap - nasjonale rammebetingelser}

Denne bokens fokus på politisk lederskap har avdekket de fire paradoksene som boken er organisert etter. Styrken i det politiske lederskapet vil henge sammen med hvilke rammebetingelser og tradisjoner som finnes for å håndtere paradoksene i forskjellige kontekster. Slike rammebetingelser kan både fremme og begrense politisk lederskap. Samtidig handler politisk lederskap også om å endre rammebetingelsene. Dermed vil utvikling av lokalpolitisk lederskap og dets rammebetingelser i seg selv være gjenstand for politisk lederskap. Denne typen overordnet politisk lederskap kan utspille seg lokalt, for eksempel gjennom at politikerne endrer de lokale rammene for politikkutforming. I de foregående kapitlene har vi vist en rekke eksempler på slike lokale endringer, som alle sammen skjer innenfor en bestemt nasjonal legal ramme. Men utviklingen av rammebetingelser kan også gjelde det norske kommunesystemet som sådan. Det er dette nasjonale perspektivet som ligger til grunn for diskusjonen nedenfor. Spørsmålet en kort og godt hva storting, regjering 
og nasjonale organisasjoner som KS kan gjøre dersom målet er å styrke det lokale politiske lederskapet.

Diskusjonen rundt de fire paradoksene har vist at de vokser ut av sentrale spenninger mellom ulike hensyn som styringssystemet forsøker å realisere samtidig. Det handler for eksempel om spenningen mellom konsensus og konflikt, mellom administrasjon og politikk, mellom åpenhet og lukkethet og mellom direkte og indirekte deltakelsesformer. Ulike land veier disse hensynene ulikt, noe som skyldes mange og kompliserte forhold. På overflaten vil nasjonale ulikheter i politisk lederskap gjerne følge av formelle regler, for eksempel som følge av at kommunelovningen er ulik fra land til land. Men lovgivningen er ofte uttrykk for dypereliggende styringskulturer og tradisjoner. Selv om større styringstrender som New Public Management kan avleses i de fleste lands formelle rammebetingelser for politisk lederskap, er det likevel betydelige forskjeller som må forklares på andre måter.

I denne boken har vi rettet søkelyset spesielt mot Norge og Danmark, to land som, når det gjelder kommuner og lokalpolitikk, er omtrent så like som to land kan bli. Likevel finner vi også her betydelige forskjeller knyttet til de fire paradoksene og deres underliggende spenninger. Danske kommuner har en sterkere tradisjon for konsensus enn norske, og danske ordførere er mer involvert i administrasjonen enn sine norske kollegaer. Det er mer vanlig å lukke politiske møter i Danmark sammenliknet med i Norge, og Danmark har en lengre tradisjon for direkte demokrati i samspill med representasjon.

Hvert land må forstås på egne premisser. Selv om det kan være fristende å trekke normative konklusjoner ut fra disse forskjellene, så er det ikke noe mål at Norge skal bli som Danmark. Fordi styringssystemer i ulike land er forankret i ulike kulturelle, historiske og sosiale forhold, er det heller ikke gitt at blind kopiering av ordninger og praksiser fra andre land leder til et ønsket resultatet. Gevinsten ved å sammenlikne Norge med et annet land, slik vi har gjort i denne boken, ligger snarere i at sammenlikningen bidrar til å klargjøre hva som er spesielt, den inviterer til å reflektere over trekk ved det norske systemet, og den gir anledning til å 
debattere i hvilken grad vi ønsker å dyrke det særegne, eller om vi ønsker å endre noe. Hvis det sistnevnte er tilfellet, vil sammenlikninger med andre land bidra til å få frem gode ideer som, med nødvendige tilpasninger, kan lede til ønskede endringer.

Styringssystemer er vanligvis stabile over tid. De endres bare unntaksvis, og da typisk gjennom mindre tilpasninger. Hvis vi tenker oss norsk kommunesektor som et slikt styringssystem, så har systemet vært gjenstand for mange mindre endringer over tid, men større endringer har vi sett færre av. Den viktigste endringen i moderne tid skjedde tidlig på 1990-tallet da kommuneloven ble revidert, og da det tydelige skillet mellom politikk og administrasjon ble lovfestet sammen med for eksempel reglene om generell møteoffentlighet (NOU 1990: 13).

At styringssystemer er stabile, har en verdi i et demokrati. De fleste land har derfor helt bevisst etablert beslutningsprosedyrer som medfører at større systemendringer, for eksempel endringer i konstitusjonen, bare kan skje gjennom langvarig og omfattende saksbehandling. Endringer i den norske grunnloven kan være et eksempel på dette. I tråd med dette normative prinsippet er det vanligvis lenge mellom hver gang en lov blir gjenstand for omfattende revisjoner, og det gjelder også for de lovene som er mest relevante med tanke på de fire paradoksene som denne boken har diskutert. Men selv om stabile legale rammebetingelser har en egenverdi, så skal styringssystemene like fullt virke i en verden i rask endring. Det tilsier at vi kontinuerlig bør vurdere om rammebetingelsene er tilpasset den virkeligheten de skal regulere og virke i.

Med dette som utgangspunkt skal vi diskutere hvilke typer endringer på nasjonalt nivå som kan være relevante dersom vi ønsker å endre betoningen av de motstridende hensynene som har gitt opphav til de fire paradoksene diskutert i denne boken. I tabell 6.1 har vi gitt noen eksempler på aktuelle endringer. Tabellen skiller mellom endringer knyttet til formelle rammebetingelser i form av lover og forskrifter, og mer uformelle endringsfaktorer knyttet til holdninger og forestillinger som kan bearbeides gjennom informasjon og veiledning i regi av for eksempel departementene og KS. 
Tabell 6.1 Eksempler på mulige nasjonale endringsfaktorer for å styrke lokalt politisk lederskap

\begin{tabular}{|c|c|c|c|}
\hline Paradoks & Sentral spenning & $\begin{array}{r}\text { Endre sentrale lover } \\
\text { og forskrifter }\end{array}$ & $\begin{array}{r}\text { Påvirke forestillinger } \\
\text { og holdninger }\end{array}$ \\
\hline $\begin{array}{l}\text { Konflikt- } \\
\text { paradokset }\end{array}$ & $\begin{array}{r}\text { Partikonflikt versus } \\
\text { konsensus }\end{array}$ & $\begin{array}{r}\text { Valgloven } \\
\text { Kommuneloven }\end{array}$ & $\begin{array}{r}\text { Spre informasjon om } \\
\text { «beste praksis» }\end{array}$ \\
\hline $\begin{array}{l}\text { Administrasjons- } \\
\text { paradokset }\end{array}$ & $\begin{array}{l}\text { Administrativt versus } \\
\text { politisk lederskap }\end{array}$ & Kommuneloven & $\begin{array}{r}\text { Utvikle alter- } \\
\text { native metaforer } \\
\text { til «timeglass- } \\
\text { modellen», spre } \\
\text { «beste praksis» }\end{array}$ \\
\hline $\begin{array}{l}\text { Åpenhets- } \\
\text { paradokset }\end{array}$ & $\begin{array}{l}\text { Åpne møter versus } \\
\text { lukkende møter }\end{array}$ & $\begin{array}{r}\text { Kommuneloven } \\
\text { Offentlighetsloven }\end{array}$ & $\begin{array}{r}\text { Utvikle aksept i } \\
\text { media for «politisk } \\
\text { drodling» }\end{array}$ \\
\hline $\begin{array}{l}\text { Demokrati- } \\
\text { paradokset }\end{array}$ & $\begin{array}{r}\text { Direkte deltakelse } \\
\text { versus } \\
\text { representasjon }\end{array}$ & $\begin{array}{r}\text { Kommuneloven } \\
\text { Plan- og } \\
\text { bygningsloven }\end{array}$ & $\begin{array}{l}\text { Utvikle forestillingen } \\
\text { om «representasjon» }\end{array}$ \\
\hline
\end{tabular}

Konfliktparadokset er knyttet til spenningen mellom partikonflikt og konsensus. Dersom vi ønsker å endre balansen mellom disse to ulike hensynene, så kan dette gjøres gjennom lovendringer. Dersom vi i større grad ønsker å tydeliggjøre politisk konflikt som organiserende prinsipp, kunne vi for eksempel gjøre ordningen med kommunal parlamentarisme obligatorisk. Med en slik endring ville det ikke lenger ha eksistert noe paradoks knyttet til konflikt. Dersom vi ønsker å rendyrke konsensus, så vil det teoretisk sett være mulig å påvirke gjennom radikale endringer i valgloven eller kommuneloven, for eksempel ved at representantene rekrutteres på andre måter enn gjennom politiske partier. Men som vi har argument for i kapittel 2, så må vi se på spenningen mellom konflikt og konsensus som noe iboende, slik at det relevante spørsmålet heller blir hvordan vi eventuelt kan justere balanseforholdet mellom de to hensynene. Målet med denne diskusjonen er ikke å gi noen uttømmende svar på spørsmålet, men snarere å peke på dette som en viktig diskusjon.

På det mer uformelle plan er det mulig å tenke seg at balansegangen mellom konflikt og konsensus kan forbedres ved at eksempler på gode praksiser gjøres kjent. Som vist i kapittel 2 er det store variasjoner i måten kommunene håndterer spenningen mellom konflikt og konsensus på. Mens konflikt brukes konstruktivt i noen kommuner, er den destruktiv 
i andre. Denne variasjonen kan ha mange årsaker, men noe av den kan knyttes til prosedyrer og rutiner som lar seg overføre fra en kommune til en annen. Det forutsetter selvsagt at de involverte kjenner til de kommunene som lykkes. Derfor vil spredning av gode eksempler kunne være et aktuelt tiltak i denne forbindelsen.

Når det gjelder administrasjonsparadokset, så dreier det seg i stor grad om et bevisst valg, der profesjonell administrativ ledelse er blitt prioritert, og der dette har gått på bekostning av folkevalgtes lederskap (NOU 1990: 13). Det innebærer at folkevalgte i liten grad er involvert i de tidlige fasene i en politikkutformingsprosess. I den grad vi ønsker å involvere politikere på andre måter, er det nærliggende å oppnå dette gjennom endringer i kommuneloven. Men diskusjonen i kapittel 3 viste også at det skarpe skillet mellom administrasjon og politikk ikke bare er en følge av lovendringen i 1992, men også et resultat av måten lovens prinsipp ble visualisert på gjennom den såkalte timeglassmodellen i regi av KS. Metaforer som «timeglass» påvirker oss fordi de setter rammer for måten vi tenker om politikk og administrasjon på. Dersom vi ønsker en annen balanse mellom administrativt og politisk lederskap, så er det mulig å tenke seg at andre metaforer enn «timeglass» kan bidra til dette. I kapittel 3 argumenterte vi for at «tannhjul» kan fungere som en alternativ metafor som vil gi andre rammer for tanken enn «timeglass». Andre mulige metaforer kunne ha vært «spiral» eller «vippe». Slike alternative metaforer kunne med fordel ha blitt utviklet mer i detalj.

Til slutt vil det også her være aktuelt å spre informasjon om beste praksis. Analysen i kapittel 3 viste at det er betydelig variasjon mellom norske kommuner med hensyn til hvordan ordfører og kommunedirektør forholder seg til hverandre til daglig. Selv om mye av dette kan skyldes personlige egenskaper ved de to aktørene, så kan det også være snakk om rutiner, prosedyrer og praksiser som eventuelt kan overføres til andre kommuner.

I likhet med administrasjonsparadokset, er også åpenhetsparadokset knyttet til et bevisst valg gjort i forbindelse med ny kommunelov tidlig på 1990-tallet. Stortinget valgte da å gjøre alle politiske møter i norske kommuner åpne for publikum og media. I utvalget som utredet ny kommunelov i 2016, var det dissens om dette spørsmålet (NOU 2016: 4), men 
Stortinget valgte å beholde de opprinnelige reglene. I kapittel 4 har vi behandlet dette paradokset gjennom å drøfte spenningen mellom åpenhet og lukkethet og knytte dette til begreper som «arbeidsmøter» og «symbolmøter». Den empiriske analysen viser at møteoffentlighet har konsekvenser for innholdet i møtene, og mens danske politikere gjennomgående har sine «arbeidsmøter» i formelle og lukkede utvalgsmøter, så er det parti- og gruppemøter som fyller denne funksjonen i Norge.

Det er gode argumenter for møteoffentlighet, men det finnes også gode argumenter imot. Hvis vi ønsker å endre balanseforholdet mellom de to motstridende verdiene, så vil det mest nærliggende være å endre lovbestemmelsene rundt møteoffentlighet. Men i tillegg kan vi også forestille oss at åpenhetsparadokset kan håndteres gjennom endringer i journalisters og medias forventninger og arbeidsmåte i dekningen av lokal politikk. I dag forutsetter media at en politiker alltid har konklusjonen klar i enhver sak, og det er liten aksept for at også politikere iblant trenger å famle seg frem til en konklusjon. Dermed blir det en risikosport å fremstå som nølende og usikker i åpne møter - det er noe politikerne heller gjør blant politiske venner i partiets gruppemøter. Med større aksept i media og blant journalister for at også politikere trenger å diskutere fritt og uten å forplikte seg på bestemte vedtak, kunne kanskje også åpne møter ha fungert som «arbeidsmøter»? I så fall ville argumentet for lukkede møter mer eller mindre falle bort.

Demokratiparadokset, som er det siste av de fire paradoksene, er knyttet til spørsmålet om hvordan vi kan forene ideen om det suverene folk med ideer om politisk lederskap og politisk representasjon. På den ene siden bygger ideen om det suverene folk på at innbyggerne selv medvirker i beslutninger som angår dem selv, samtidig som det representative systemet innebærer at denne retten «gis bort» til valgte representanter. Spenningen mellom disse to måtene å forstå demokrati på, vil komme til uttrykk i spørsmålet om innbyggernes direkte deltakelse i beslutningsprosesser versus indirekte deltakelse gjennom representativt demokrati. Som kapittel 5 har pekt på, finnes det mange forskjellige typer deltakelsesformer i det norske lokale demokratiet. Noen er knyttet til det representative systemet, og noen fremstår som alternative og konkurrerende kanaler for deltakelse. I kapittel 5 har vi også gitt eksempler på en 
mellomvariant der direkte deltakelse og representasjon forsøkes forent gjennom såkalte oppgaveutvalg.

Ethvert moderne demokrati må håndtere spenningen mellom deltakelse og representasjon. Noen land, som Sveits, har valgt å legge stor vekt på direkte deltakelse, mens andre land, som Norge, har en sterkere tradisjon for representasjon. Hvis vi ønsker å endre balanseforholdet mellom de to formene for demokrati, så vil det være nærliggende å gjøre endringer i lovverket. For eksempel kunne bindende folkeavstemninger ha blitt innført på nye områder, eller nye former for deltakelse kunne ha blitt introdusert i det norske lovverket, for eksempel såkalt borgerbudsjettering der lokalsamfunn eller frivillige organisasjoner får prioritere mellom ulike formål innenfor en ramme fastsatt av valgte politikere.

Men også her vil det være mulig å bearbeide spenningen mellom direkte deltakelse og representasjon gjennom å påvirke forestillinger og holdninger. Ikke minst vil det være interessant og relevant å reflektere over hva ordet representasjon innebærer. Politikere er valgt for fire år, men hva er de egentlig valgt til å gjøre? Et klassisk svar på spørsmålet er at politikerne har fått fullmakt til å styre for en periode, og deretter må de stå til ansvar i et valg. Men denne forestillingen kan utfordres gjennom at vi ser på representasjon mer som en rett og plikt til å knytte sammen folk og politikk, slik vi diskuterte i kapittel 1 . I et slikt perspektiv vil de folkevalgtes oppgave være å utforme politikk som til dels er basert på partiprogrammer, men også på løpende dialog med innbyggerne valgperioden igjennom.

\section{Læringsarenaer for lokalt politisk lederskap}

Mens første del av dette kapitlet tok utgangspunkt i hvordan de nasjonale rammebetingelsene for kommunene kan endres, så skal vi nå rette blikket mot det lokale nivået. Det vi er opptatt av nå, er hva den enkelte politiker og det enkelte kommunestyret kan gjøre, gitt rammebetingelsene, dersom de ønsker å utvikle eget så vel som kollegiets politiske lederskap. Vi starter med noen refleksjoner rundt selve fenomenet politisk lederskap, før vi diskuterer ulike arenaer som kan være aktuelle for å utvikle politisk lederskap. I et eget kapittel viser vi hvordan et slike tiltak kan organiseres. 
En norsk bokhandel rommer mange bøker om administrativt lederskap og ledelse i bedrifter, og denne typen lederskap er, i alle fall delvis, blitt et akademisk fag med egne utdanninger på universitetsnivå. Slik er det ikke med politisk lederskap. Utøvelse av politisk lederskap er ikke og kan ikke være - et akademisk fag med standard lærebøker og et sett av standardiserte metoder som valgte politikere kan lære seg og benytte seg av (Offerdal, 1989). Dette illustreres godt i en internasjonal spørreundersøkelse i 21 land, hvor man fant at nesten ingen land har systematiske opplegg for opplæring og utvikling av politiske ledere (Reading et al., 2011). Det finnes riktignok mange (selv)biografier skrevet om og av politiske ledere, men noen etablert oppskriftsbok på politisk lederskap finnes ikke.

Dette til tross mener vi at politisk lederskap er noe som kan læres og trenes opp. Imidlertid skjer det ikke først og fremst gjennom teoretisk skolering, men heller i praksis og gjennom dialog mellom politikere, med administrative ledere og innbyggerne. Det er med andre ord ikke snakk om å lære seg et fag, men om å gjøre seg kjent med forskjellige ideer og former for politisk lederskap samt å reflektere over hvordan de rette betingelsene for politisk lederskap kan skapes.

Ulike typer opplærings- og utviklingsprogrammer som har til hensikt å bevisstgjøre valgte politikere om deres rolle og funksjon, er en viktig del av et demokrati, ikke minst i et lokalt demokrati med sterke lekmannsidealer, slik tilfellet er i Norge. Men slike programmer er trolig mindre utbredt enn de kunne og burde være. En viktig og nødvendig side ved folkevalgtprogrammer handler om å utvikle en klar forståelse for de konstitusjonelle, juridiske, institusjonelle og organisatoriske rammene for politikkutvikling. Når det gjelder Norge og norsk lokalpolitikk, tilbyr eksempelvis KS et folkevalgprogram med en felles ramme og ulike lokale variasjoner (Kommunenes Sentralforbund, 2015, 2019), og seminarene som avholdes lokalt, bidrar til å avklare politikernes ulike roller og rommet for politisk lederskap. I tillegg til slike nasjonale initiativ finnes det også ulike lokalt utviklede programmer for folkevalgte.

De fleste slike programmer har et «utenfra-og-inn perspektiv»på politisk lederskap. Programmene retter søkelyset mot de ytre handlingsbetingelsene gjennom å presentere de formelle rammene for utøvelsen 
av politisk lederskap. På mange måter er det begrensningene på politisk lederskap som formidles, med vekt på hva som er lovlig, hva som er økonomisk mulig, hva som er etisk forsvarlig, og så videre. Dette representerer viktige rammebetingelser for politisk lederskap som folkevalgte må ha et aktivt forhold til. Men «utenfra-og-inn»-perspektivet medfører samtidig en viss risiko for at politikerne kan miste motet dersom rommet for politisk lederskap viser seg å være mye mindre enn de forventet før de ble valgt. Denne risikoen er størst når «utenfra-og-inn»-perspektivet får stå alene med den sterke oppmerksomheten på begrensningene.

Det alternative «innenfra-og-ut»-perspektivet handler snarere om å dyrke de positive mulighetene gjennom å forbedre dialogen mellom politikerne, med administrasjonen, med media, med sivilsamfunnet og med innbyggerne. Et typisk eksempel på et slikt perspektiv kalles Next Generation og er igangsatt av Institute for Civil Discourse i Washington, D.C. (University of Arizona, 2019). I USA har utfordringen først og fremst vært den sterke politiske polariseringen og et påfølgende uforsonlig debattklima basert på tankegangen om at «the winner takes it all». Den største utfordringen i Norge og i Skandinavia for øvrig, som jo i utgangspunktet er mer preget av konsensusdemokrati enn USA, er kanskje heller å få politikerne til å rette oppmerksomheten mot utøvelsen av politisk lederskap og mot å få øye på alle potensielle støttespillere som kan hjelpe dem frem til suksess.

Også i Norge kan vi registrere en fremvoksende debatt om politisk lederskap, ikke minst i kjølvannet av kommunereformen, som innebærer at mange kommuner slås sammen, og at ulike politiske kulturer og systemer skal smelte sammen til noe nytt. Slike prosesser gir anledning til å tenke gjennom de lokale rammene for politisk lederskap, og til å utvikle lokale rammebetingelser slik at de fremmer det politiske lederskapet. Men å reflektere rundt politisk lederskap er selvsagt like relevant i kommuner som ikke berøres direkte av kommunereformen.

Historisk sett har den viktigste læringsarenaen for politikere vært politikken selv, det vil si at folkevalgte har lært gjennom praksis og gjennom å utøve rollen som folkevalgt. I tillegg er det blitt gjennomført opplæring i regi av de politiske partiene og partienes ungdomsorganisasjoner. I mindre grad har opplæringen tatt utgangspunkt i den politiske forsamlingen 
som politikerne er medlem av, enten vi snakker om Stortinget, fylkestingene eller kommunestyrene.

I et forsøk på å systematisere ulike læringsarenaer kan det være nyttig å skille mellom arenaer orientert mot handling versus refleksjon, og om læringen er planlagt eller spontan, slik dette er illustrert i figur 6.1. Typologien nedenfor skiller mellom fire ulike typer læringsarenaer for valgte politikere: daglig politikk, spontan refleksjon, organisert læring og gjennomtenkt utprøving (Hartley 2011).

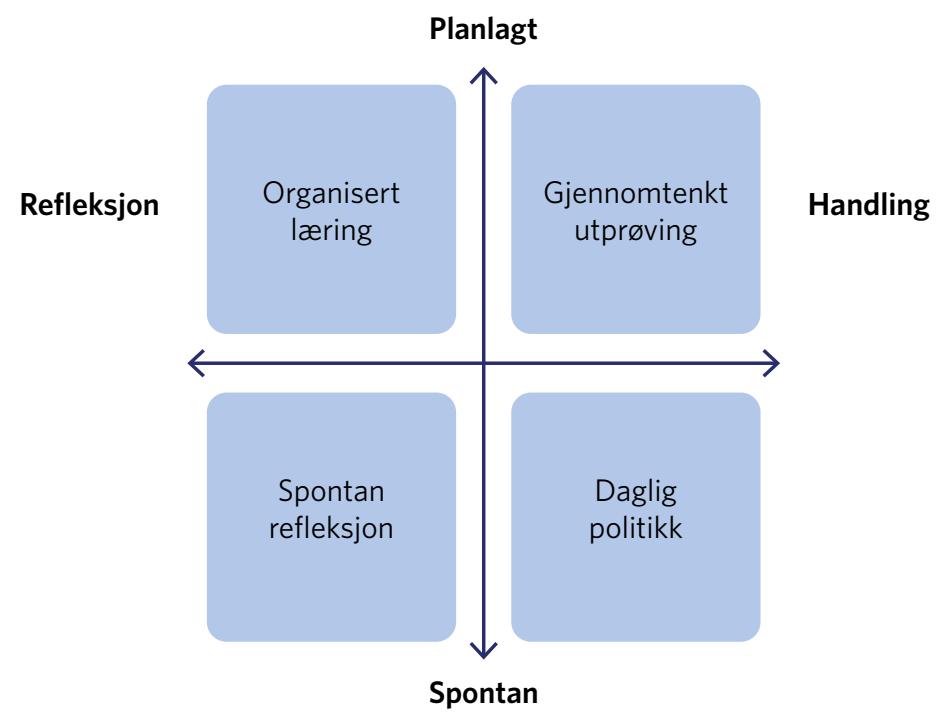

Figur 6.1 Fire læringsarenaer for politisk lederskap (inspirert av Hartley, 2011)

Læring gjennom daglig politikk er nært knyttet til handling og spontanitet, og læringen skjer gjennom aktiviteter som politiske møter, partimøter, møter med ulike interessenter, politiske debatter og uformelle samtaler med andre politikere - kort sagt det som fyller den politiske hverdagen for norske kommunepolitikere. Det er liten tvil om at mye av læringen blant norske folkevalgte skjer på denne måten, under fanen «veien blir til mens du går». Men dette er en læringsarena med begrensninger, spesielt dersom målet er å utvikle kommunestyrets kollektive lederskap. Den daglige politikken vil ofte være preget av partikonflikt og partipolitiske posisjoneringer, slik vi diskuterte i kapittel 2, og i praksis 
vil derfor læringen på denne arenaen i stor grad foregå i samspill med partifeller som i utgangspunktet deler samme syn på ulike saker. Tiden til refleksjon er dessuten begrenset, ettersom det for politikerne handler mest om å forstå og utnytte de eksisterende rammene og om å posisjonere seg riktig for å oppnå mest mulig gjennom det politiske spillet.

Læring gjennom spontan refleksjon henspiller på at politikerne også møtes mer uformelt og dermed har anledning til å reflektere rundt politikk og politisk lederskap ved å reise spørsmål om hvordan noe kan settes på dagsordenen, hvem som skal uttale seg til media i en bestemt sak, eller om det er en god idé å trekke innbyggerne inn i diskusjoner om endring av - eksempelvis - skolestrukturen. Relevante aktiviteter i den forbindelse kan være noe så enkelt som uformelle diskusjoner i lunsjpausen under kommunestyremøter, eller andre former for kontakt der politikere treffes. Denne formen for læring er verdifull, men har også sine begrensninger. De som møtes uformelt, vil ofte være de som uansett har mye kontakt med hverandre i den daglige politikken, og bare unntaksvis vil spontan refleksjon foregå i en hel forsamling av politiske ledere. Som vi har diskutert i kapittel 4, legger også norske regler om møteoffentlighet begrensninger på muligheten for at alle politikere kan møtes uten at offentligheten har anledning til å være til stede.

Organisert loering finner sted når eksempelvis et kommunestyre setter av tid til refleksjon løsrevet fra daglig politikk. KS sitt folkevalgtprogram er et eksempel på denne typen læring. Denne læringsarenaen vil som oftest involvere alle medlemmer i en politisk forsamling, og utgangspunktet kan være informasjon og diskusjon omkring roller og regler («utenfraog-inn»), eller refleksjon rundt hva som kan gjøre politisk lederskap mer interessant og effektivt («innenfra-og-ut»). Dersom utgangspunktet er å utvikle det kollektive politiske lederskapet, for eksempel å forbedre måten et kommunestyre arbeider på, sier det seg selv at denne læringsarenaen er viktig og nødvendig. Ulempen med denne læringsarenaen er at det koster både tid og penger å samle en hel komité eller et kommunestyre, og erfaringsmessig er det heller ikke alle som ønsker eller har anledning til å delta. Norske regler for møteoffentlighet medfører dessuten at denne læringsarenaen ikke kan lukkes for offentlighetens innsyn, noe som kan påvirke innholdet. 
Gjennomtenkt utprøving handler om at nye tiltak og ideer blir eksperimentert med og prøves ut, gjerne i kombinasjon med en eller annen form for evaluering. Konkret kan det være snakk om en ny måte å sette opp sakslisten på, en ny måte å lede møter på, en ny form for organisering av den politiske debatten eller nye måter å komme i dialog med innbyggerne om lokale problemer og mulige løsninger på. Slike tiltak vil ofte springe ut av organisert læring, men kan også være basert på spontan refleksjon eller daglig politikk. Hvis læring skal føre til endring, er det nødvendig at nye ideer prøves ut. Men endring for endringens skyld er sjelden en god idé. Derfor kan det være viktig at denne læringsarenaen er koblet til minst én av de øvrige arenaene. Det innebærer at det som prøves ut, må være svar på et problem som er opplevd gjennom daglig politikk, eller som er blitt reflektert over spontant eller i organiserte former.

Alle læringsarenaene diskutert ovenfor, kan bidra til å utvikle politisk lederskap, men på ulike måter. Mens spontane læringsarenaer som daglig politikk og spontan refleksjon sannsynligvis utspiller seg mellom enkeltpolitikere eller i partigrupper, er det først og fremst organisert læring som er egnet til å få et helt kommunestyre til å reflektere over politisk lederskap.

Denne boken setter søkelyset på politisk lederskap og spesielt på kommunestyret som en arena for kollektivt politisk lederskap. Boken tar med andre ord opp temaer som er skreddersydd for en såkalt organisert læringsarena, slik det er vist i figur 6.1. I bokens aller siste kapittel viser vi et eksempel på hvordan en slik arena kan fylles med konkret innhold.

Til slutt vil vi understreke at dersom læringsprosessen skal lede til faktiske endringer, så er også den fjerde læringsarenaen som er omtalt i figur 6.1, nødvendig, nemlig gjennomtenkt utprøving. Det finnes en lang rekke enkeltstående tiltak som kan prøves ut for å svare på noen av utfordringene og paradoksene knyttet til politisk lederskap. Noen av dem har vært omtalt i de foregående kapitlene. Systematisk utprøving av slike tiltak - med tilhørende selvevaluering - bør være en selvsagt oppgave for ethvert norsk kommunestyre. 


\section{Referanser}

Hartley, J. (2011). Learning in the whirlwind: politicians and leadership development. Public Money \& Management, 31(5), 331-338.

Kommunenes Sentralforbund (2015). Tillit. KS Folkevalgtprogram 2015-2019. Oslo: KS.

Kommunenes Sentralforbund. (2019). Tillit. KS Folkevalgtprogram 2019-2023. Oslo: KS.

NOU 1990:13. (1990). Forslag til ny lov om kommuner og fylkeskommuner. Hentet fra https://www.regjeringen.no

NOU 2016: 4. (2016). Ny kommunelov. Hentet fra https://www.regjeringen.no

Offerdal, A. (1989). Politisk ekspertise - finst den? Om politikarens plass $i$ styringssystemet. Oslo: Kommunenes Sentralforbund.

Reading, P, A. Stansfield, J. Hartley og M. Mathias (2011). International perspectives on leadership and learning development for national politicians. Arbeidsnotat for National School of Government. Coventry, England: University of Warwick.

Røiseland, A. \& Lo, C. (2019). Samskaping - nyttig begrep for norske forskere og praktikere? Norsk statsvitenskapelig tidsskrift, 35(1), 51-58. https://doi.org/10.18261/ issn.1504-2936-2019-01-03

University of Arizona. (2019). National Institute for Civil Dicsourse, The University of Arizona. Hentet fra https://www.facebook.com/ NationalInstituteForCivilDiscourse/ 


\section{Alle politikere er ledere!}

Tekst: Asbjørn Røiseland. Intervju foretatt 27. januar 2020.

Lene Conradi er ordforer i Asker kommune, og hun mener at tydelig politisk lederskap er helt nodvendig for et konstruktivt samspill med en profesjonell og eksperttung kommuneadministrasjon.

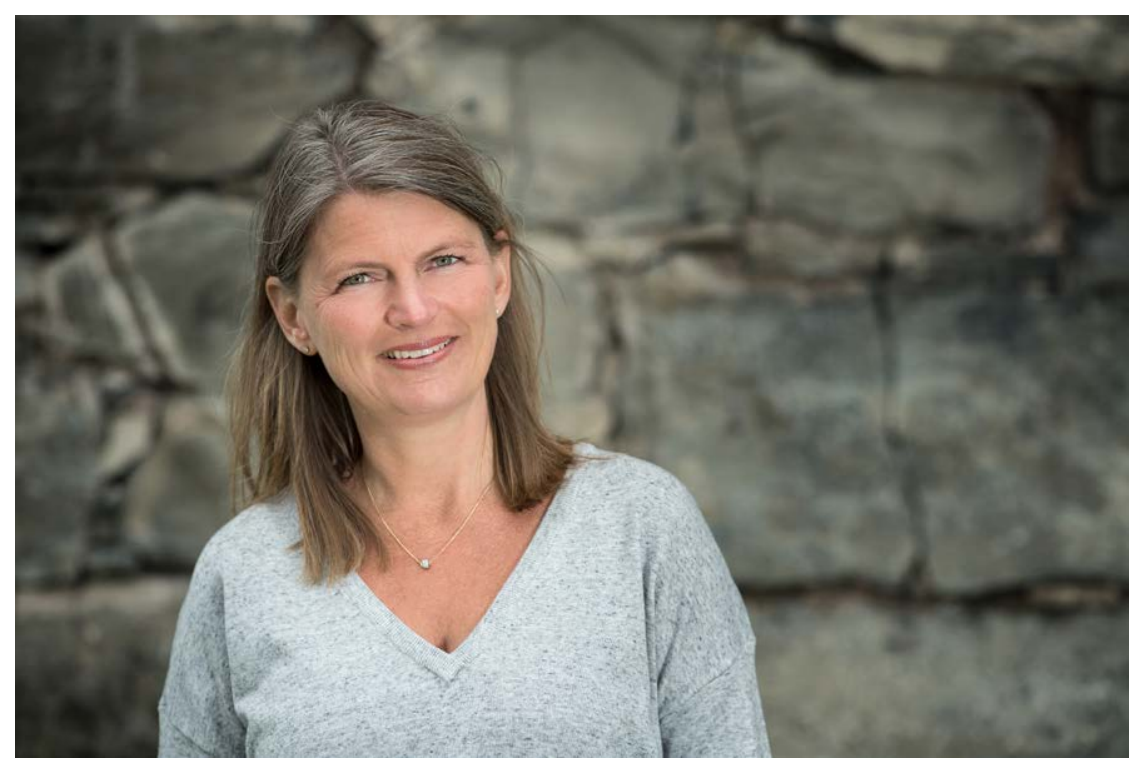

NY KOMMUNE: «Vi skal utvikle en ny kommune, og vi trenger å styrke det politiske lederskapet gjennom å fokusere på politikernes lederrolle», sier ordfører Lene Conradi i Asker kommune. (Foto: Torbjørn Tandberg. Bildet er gjengitt med tillatelse og omfattes ikke av bokens lisens.)

Mens mange politikere først og fremst har vært opptatt av ombudsrollen, mener Conradi at rollen som leder har vært underkommunisert.

«Kanskje er det en ryggmargsrefleks - det er lett for politikere å se seg selv som ombud. Og selv om det er viktig å være ombud, så må en ikke glemme å være leder, det er like viktig», sier Conradi. 
Conradi er ordfører på det trettende året, men hun omtaler seg hovedsakelig som nyvalgt ordfører. Det skyldes at gamle Asker kommune nylig ble slått sammen med Hurum og Røyken. For mange av innbyggerne i nye Asker kommune er hun deres nye ordfører. At kommunen står midt i en sammenslåingsprosess, setter sitt preg på både det ene og det andre.

\section{Nye Asker}

Den nye kommunen består av gamle Asker, som i utgangspunktet var en stor kommune (62 ooo innbyggere), og to mindre kommuner, nemlig Røyken (22 ooo innbyggere) og Hurum (900o innbyggere). De tre kommunestyrene som nå er smeltet sammen til ett, var forskjellige på mange måter. For eksempel var politikerne i de to mindre kommunene vant til å diskutere konkrete saker på et mye mer detaljert nivå enn politikerne i Asker, som har hatt en lang tradisjon for å «overlate» detaljene til administrasjonen. «Også debattkulturen var forskjellig, kunne vi merke oss, med en litt «røffere» uformell tone og form fra talerstolen i de mindre kommunene», forteller Conradi.

For ordføreren er det viktig at alle politikerne føler seg inkludert og velkommen i den nye kommunen, og at kommunestyret og formannskapet kan jobbe konstruktivt sammen. «For selv om det selvfølgelig finnes politiske brytninger som skal synliggjøres i både debatt og vedtak, så er mye av det vi driver med, forvaltning, der vi lett kan være enige. Vi trenger å bygge tillit og troverdighet overfor 6000 ansatte og 94000 innbyggere, spesielt nå som en ny kommune skal bygges», sier Conradi.

Kommunens ledelse har gjort flere endringer for å lette prosessen med å smelte sammen tre tidligere kommuner. Mens gamle Asker kommune kun hadde én heltidspolitiker gjennom ordførervervet, er flere politikere nå blitt frikjøpt, noe som er ment å styrke det politiske lederskapet. I tillegg gjennomfører kommunen et egenutviklet og skreddersydd folkevalgtprogram for alle politikere. Dette skal bidra til at det politiske lederskapet kan matche en meget kompetent organisasjon som er svært opptatt av endringsledelse, og som investerer i et skreddersydd organisasjonsutviklingsprogram for sine ledere og ansatte. 
Også på det mellommenneskelige plan er det blitt gjort uvanlige ting, for eksempel at ordføreren inviterte hele formannskapet hjem til middag.

«Vi hadde en runde rundt bordet ... Er det ikke sånn i alle sammenhenger, at du som leder må pleie relasjoner? Jeg tror genuint på at om man lærer hverandre å kjenne og blir trygge på hverandre i et kollegium, så vil det bidra til et bedre samspill, bedre debatter og til syvende og sist også bedre løsninger. Å legge inn noen sosiale treffpunkt i tillegg til de faste arbeidsmøtene tror jeg bidrar til dette», sier Conradi.

\section{Fokus på lederrollen}

Conradi er spesielt opptatt av å dyrke og styrke den lederrollen politikerne i Asker kommune har, særlig tatt i betraktning at Asker er en ny kommune hvor både innbyggere og andre har store forventninger.

«Mange politikere har erfaring med ledelse fra før, gjennom yrkeslivet. Men det gjelder selvsagt ikke alle, og det er viktig å sikre at alle har like gode forutsetninger for å utøve sitt lederskap. Og uansett er det viktig å diskutere politisk lederskap både i dag og i fremtiden», sier Conradi. «Fra mitt perspektiv må vi tenke annerledes rundt politisk lederskap i tiden fremover. Vi har vært en typisk 'ja-kommune' med god økonomi, men vi kommer til å bli en kommune som må prioritere mer. Vi må sannsynligvis involvere innbyggerne mer, og spille enda mer på lag med frivilligheten, for å opprettholde tjenestetilbudet. Vi må tåle mer spleis, og for meg blir dette en viktig side ved det politiske lederskapet fremover», fortsetter hun.

I Asker kommune er de svært opptatt av den politiske lederrollen i kommunens eget folkevalgtprogram. Programmet består av ulike deler og gjennomføres av Asker kommune, KS og eksterne konsulenter. Målet er at opplæringen skal oppfattes som relevant, nyttig og motiverende, sikre at de folkevalgte er innforstått med sine egne roller og ansvar, og samtidig vise hvilket handlingsrom som ligger i styring av en helt ny kommune i et lokalsamfunn. 


\section{Eget folkevalgtprogram}

Asker kommunes program for politisk lederutvikling består av et fellesprogram for alle politikere, som går over to dager. Dette opplegget bygger på KS sitt folkevalgtprogram. I tillegg gjennomfører alle utvalgene sine opplegg, basert på diskusjoner blant utvalgslederne og de tilhørende direktørene om hva som bør vektlegges. Her vil utvalgsmedlemmene fordype seg i sine ansvarsområder, og de får både introduksjoner til temaer, presentasjoner av virksomheter og veiledning i formelle prosesser parallelt med at de skal behandle politiske saker.

Formannskapet har et utvidet opplegg med tydelig vekt på ledelse. Formannskapet består av ordfører og varaordfører og lederne for de fem hovedutvalgene i kommunen, og det regnes derfor som det sentrale koordinerings- og ledelsesorganet. Kommunen har inngått avtale med et konsulentfirma om opplæringstiltak, der opplegget vektlegger politisk ledelse og demokratiet som styringsform. Programmet vil være spesielt rettet mot følgende:

- Personlig lederskap - politikernes evne og vilje til å bruke eget engasjement i lederrollen.

- Ledelse og endring - politikernes retoriske evne til å tydeliggjøre retning, krav og samhandling.

- Rollebevissthet - politikernes forståelse av egen rolle og håndtering av forventninger og utfordringer på en proaktiv fremfor en reaktiv måte.

- Miljøskapere - forståelse og ferdigheter i hvordan man skaper et sterkt miljø for skaperkraft og resultatoppnåelse.

- Mestring - mestringsstrategier for håndtering av krav, forventninger og arbeidspress.

- Relasjonsledelse - politikernes evne til å nå resultater sammen med andre.

- Kommunikasjon i relasjon - ledernes evne til å se andre og eget ståsted. 


\section{Spent på kritikk}

Som ledd i Asker kommunes folkevalgtprogram skal formannskapet dra til Firenze på studietur med et skreddersydd program for folkevalgt ledelse, med vekt på at Asker er en ny kommune. Conradi er overbevist om nytteverdien av denne reisen, og om at opplegget bidrar til at hvert enkelt medlem får en forståelse av sin egen lederrolle, og i tillegg av lederrollen hver enkelt har i et kollegium som formannskapet. Slik sett er det vel anvendte ressurser med hensyn til bruk av både tid og penger. Samtidig er hun spent på hvordan reisen blir mottatt blant innbyggerne og media. Det er alltid krevende å kommunisere betydningen av politisk lederutvikling, spesielt når det blir snakk om reisevirksomhet. I 2014 dro formannskapet til Roma på en tilsvarende tur med et tett faglig program. Den gangen mottok kommunens ledelse kritikk for såkalt parlamenturisme, men alle som deltok på turen til Roma, forsvarte tiltaket som godt, relevant og nødvendig for å bevisstgjøre og utvikle det politiske lederskapet. Dette er bakgrunnen for at fellesnemnda har forberedt en folkevalgtopplæring rettet mot lederskap. 


\title{
Eksempel på folkevalgtprogram rettet mot politisk lederskap
}

\author{
Tekst: Asbjørn Røiseland, Eva Sørensen, Jacob Torfing
}

Kjernen i det politiske lederskapet er å sette dagsorden, utvikle visjonære løsninger og sette dem ut $\mathrm{i}$ livet. Det er god grunn til å anta at de fleste politikere faktisk ønsker å bruke tid på å utvikle politikk, men samtidig fyller dette bare en liten del av politikernes hverdag. Skal politikkutvikling bli en viktigere del av politikernes hverdag, så må det skapes mer tid og rom for å diskutere politikk i kommunestyret. Men dette forutsetter at politikerne har lyst til å fungere som politiske ledere gjennom å sette den politiske dagsordenen og utvikle og gjennomføre nye løsninger.

I 2017 og 2018 ble det gjennomført et forsøk med et alternativt folkevalgtprogram der et utvalg kommunestyrerepresentanter deltok på et dagsseminar om politisk lederskap. Forsøket ble gjennomført i regi av KS og omfattet kommunestyrene i Asker, Hurum, Røyken, Oppegård, Ski og Austrheim. ${ }^{5}$ Hensikten var å teste ut et «innenfra-og-ut»-opplegg (se kapittel 6) der man fokuserte på de positive mulighetene for å utvikle det politiske lederskapet med utgangspunkt i et kommunestyre, og med alle i kommunestyret som deltakere.

Programmet for seminarene inneholdt en kombinasjon av korte foredrag, gruppearbeid og diskusjon i plenum, og temaene som ble tatt opp, fremgår av figuren nedenfor. I det følgende skal vi kort gjennomgå innholdet i de ulike programpostene.

5 De tre førstnevnte ble til nye Asker kommune, mens Oppegård og Ski ble til Nordre Follo kom-
mune fra 2020 . 
o8:30 Velkomst og presentasjon av formål og program for dagen

o9:oo Faglig opplegg: Politisk ledelse - hva er det, og hvorfor er det viktig?

09:30 Tema 1: Hvorfor ble du politiker? Om motivasjoner for politikk

10:30 Pause

10:45 Tema 2: Hvordan sikrer man gode vilkår for politisk debatt blant politikerne?

12:00 Lunsj

12:45 Tema 3: Hvordan kan administrasjonen bidra til å styrke politisk ledelse?

13:45 Tema 4: Hvem kan hjelpe med å forstå problemer/utfordringer, samt finne nye løsninger?

15:00 Tema 5: Hvordan blir politikerne og kommunestyrets arbeid synlig i offentligheten?

15:30 Avrunding og oppsummering, diskusjon om videre oppfølging

16:0o Programmet avsluttes

Figur Eksempel på programoppsett for heldagsseminar for et kommunestyre

\section{Tema 1: Motivasjoner for politikk og politisk lederskap}

Den felles opplevelsen av at man vil utvikle lokalsamfunnet på beste måte og gjøre en positiv forskjell for forskjellige grupper, danner et felles utgangspunkt for politisk handling og representerer dermed en minimumsenighet blant politikerne. For å utvikle det kollektive politiske lederskapet kan det være en god idé å få medlemmene i et kommunestyre til å minnes de begivenhetene og personene som i sin tid inspirerte dem til å gå inn i politikken. Kanskje var det bestemte spørsmål eller saker som de brant for, og som de gjerne ville gjøre en forskjell for? Ved å dele disse politiske motivasjonene med hverandre - først i mindre grupper og siden i plenum - blir det sannsynligvis klart at de aller fleste folkevalgte er motivert ut fra ønsket om å skape et bedre lokalsamfunn med høy trivsel, velferd og bærekraft. Kanskje blir det også klart at politikere fra vidt forskjellige partier kan være motivert av samme politiske sak - et 
ønske om å gjøre noe bedre for unge, gamle, barnefamilier, næringslivet eller idretten. Gjennom bevissthet om hverandres motivasjoner skapes et felles utgangspunkt for kollektivt politisk lederskap. Selv om det trolig vil være stor forskjell i politiske løsningers innhold, så finnes det felles dagsordener som de folkevalgte kan velge å konsentrere seg om.

Dette kan fungere som en plattform for utøvelse av politisk lederskap og for å opptre samlet overfor både administrasjon og innbyggerne. Dette betyr likevel ikke at de politiske konfliktene forsvinner. Så snart konkrete løsninger skal finnes, vil de forskjellige politiske og ideologiske forskjellene og behovet for å markere seg skape uenigheter og konflikter. Dette vil imidlertid være politiske konflikter som knytter seg til retningen og innholdet i det politiske lederskapet, og som utspiller seg innenfor en politisk ramme som politikerne selv har vært med på å etablere.

\section{Tema 2: Vilkår for politisk debatt}

Folkevalgte politikere er politisk interesserte folk med stor arbeidskapasitet og evne til å bearbeide en stor mengde informasjon. Likevel vil det være vanskelig, for ikke å si umulig, å utøve det politiske lederskapet i et tomrom uten bidrag fra andre. Derfor er det en god idé for politikere å søke hjelp og inspirasjon hos andre aktører som kan bidra til å klarlegge problemer og utfordringer, utvikle løsninger og gjennomføre dem i praksis. I det følgende skal vi peke på noen aktører som vil kunne være viktige samtalepartnere og hjelpere.

En første «hjelper» er de andre folkevalgte. Politikere kan i stor grad bruke hverandre til å stimulere utviklingen av politiske ideer, strategier og forslag. Det politiske utviklingsarbeidet kan skje i partigruppene, på komité- og utvalgsmøter eller i felles dialog på tvers av partiene. Dialogbasert politikkutvikling krever at det etableres rom og arenaer der det er plass og tid til politiske diskusjoner, og der man respekterer hverandres forskjellige synspunkter på tross av politisk uenighet.

Politikere har mange oppgaver. De skal delta i lokale partilag og gruppemøter, lese lange saksutredninger, delta i komité- og utvalgsmøter, orientere seg på sosiale medier, tvitre og så videre. I en travel hverdag skorter det ofte på tid til tverrgående og utviklingsorienterte politiske 
diskusjoner. For å rydde tid og rom til slike diskusjoner kan det være en god idé at folkevalgte reflekterer hver for seg og sammen over hvor det allerede finnes diskusjonsarenaer som kan utvikles videre, og hvordan det kan skapes nye arenaer for diskusjon.

En god politisk debatt på tvers av politiske forskjeller bidrar til å skape det politiske lederskapet som er nødvendig for å bringe lokalsamfunnet videre. Men uten et godt debattklima og plass til forskjellighet blir det vanskelig å sette en politisk dagsorden for det kommunale fellesskapet, utvikle nye løsninger og få støtte og oppslutning til å føre nye ideer ut i livet. Hvis den politiske debatten kun ender i posisjonering og destruktive konflikter, så blir det vanskelig å utvikle politiske løsninger. I verste fall vil innbyggerne bare få bekreftet forestillingen om at politikere er mest opptatt av å skape oppmerksomhet rundt seg selv og sitt eget parti og minst opptatt av å løse lokalsamfunnets problemer og utfordringer.

Det er liten tvil om at det er vanskelig for politikere fra forskjellige politiske partier å utforme felles løsninger på komplekse problemer og utfordringer. Utviklingen av et godt og konstruktivt debattforum basert på gjensidig respekt for hverandres synspunkter og nysgjerrighet på andres ideer, gjør det likevel mulig for politikerne å inspirere hverandre og gjøre bruk av den kollektive fornuften som finnes i en politisk forsamling.

\section{Tema 3: Administrasjonens bidrag til politisk lederskap}

Politikere kan hjelpe hverandre med å styrke utøvelsen av politisk lederskap, men de kan også få stor hjelp av administrasjonen. Kommunens administrasjon er en permanent organisasjon som løpende samler opp og bearbeider kunnskap, ideer og erfaringer. God tilgang til disse ressursene er avgjørende for politikernes mulighet til å utøve politisk lederskap. Det er ofte administrasjonen som på eget initiativ formidler informasjon, kunnskap og ideer til politikerne. Det skjer løpende som del av saksutredninger til kommunestyret, men noen ganger også tidligere i prosessen, for eksempel i forbindelse med temamøter og orienteringer om forestående saker. Administrasjonen spiller en svært viktig rolle ved å bistå politikerne i å forstå problemstillinger og mulige løsninger. 
Det er likevel viktig at politikerne også er i stand til å etterspørre relevant bistand (informasjon, kunnskap, rådgivning, sparring og inspirasjon) fra administrasjonen i forbindelse med politikkutviklingen. Det er vanskelig å reise nye saker eller initiere utvikling av nye politiske tiltak hvis man ikke har den riktige kunnskapen om lovgivningen, om hva som er blitt gjort før, og om hva man gjør andre steder. Derfor er det viktig at politikerne har mulighet for å «bestille» kunnskap fra administrasjonen, slik at politikkutviklingen kan skje på et kvalifisert grunnlag. Politiske bestillinger til administrasjonen bidrar til at de folkevalgte blir bedre i stand til å forstå problemene og utvikle nye løsninger i dialog med kunnskapsrike fagprofesjonelle i kommunen.

Det kan være en god idé at politikerne regelmessig drøfter samarbeidet med administrasjonen, hvordan det fungerer, og hvordan det eventuelt kan forbedres for å understøtte politikernes lederskap. I den forbindelse kan man også diskutere hvordan politikerne kan sikres adgang til ekstern ekspertkunnskap fra for eksempel forskere og konsulenter, og man kan utvikle en tradisjon for å dra på ekskursjoner til andre kommuner for å oppdage nye og andre typer løsninger som kan være til inspirasjon i egen kommune.

\section{Tema 4: Innbyggernes og lokalsamfunnets bidrag til politisk lederskap}

Innbyggerne og lokalsamfunnets mange forskjellige aktører kan også gi verdifulle bidrag til utviklingen av nye politiske løsninger. Det finnes mye kunnskap, ressurser og ideer i lokalsamfunnet som politikerne med fordel kan dra nytte av. Forskjellige brukergrupper har erfaring med lokale problemer og løsninger, foreninger og næringsliv har ideer til nye løsninger, og innbyggerne kan bidra til å sette nye løsninger ut i livet. Det er derfor gode muligheter for at politikk kan utvikles sammen med ulike aktører i lokalsamfunnet.

Lokalsamfunnet kan medvirke på forskjellige måter i lokal politikkutvikling. Mange kommuner har tradisjon for å innkalle til folkemøter for å diskutere nye lokalpolitiske løsninger med innbyggerne. Folkemøter kommer ofte sent i prosessen, etter at administrasjon og politikerne har 
utarbeidet et forslag til løsning. Innbyggerne vil dermed få begrenset innflytelse. I slike tilfeller bes folk egentlig om å støtte opp om løsninger som de selv ikke har vært med på å lage. Ofte vil innbyggerne være usikre på konsekvensene, og de vil av den grunn vende tommelen ned og forsøke å stoppe realiseringen av den nye løsningen gjennom forskjellige former for kritikk og protest.

I et forsøk på å unngå denne konfrontasjonen har flere kommuner begynt å invitere en bred gruppe innbyggere med i en prosess hvor de sammen med en gruppe politikere utvikler felles forslag til politiske tiltak, som kommunestyret deretter diskuterer, justerer og vedtar. Gjennom slike ordninger, som gjerne omtales som «oppgaveutvalg», har innbyggerne mulighet for å få innflytelse på så vel problemdefinisjon som innholdet i politikken. Dette er med på å sikre bred oppslutning, samtidig som samarbeidet mellom forskjellige offentlige og private parter stimulerer til læring og innovasjon. Resultatet kan i beste fall være utvikling av en løsning som er bedre enn dersom politikere hadde agert på egen hånd. Samtidig styrkes det lokale demokratiet gjennom økt medvirkning og bredere debatt. Dette skjer uten at det nødvendigvis går på bekostning av det representative demokratiet; det er fremdeles kommunestyret som utarbeider mandatet for oppgaveutvalgene, og som treffer den endelige beslutningen.

Erfaringsmessig er det likevel vanskelig å nå ut til alle befolkningsgrupper på denne måten. Politikerne kan derfor med fordel supplere oppgaveutvalg med andre tiltak, for eksempel «gjestebudsmetoden», som går ut på å kontakte to til tre representanter for en bestemt samfunnsgruppe og få dem til å invitere flere fra sin gruppe til en uformell samling for å diskutere et bestemt spørsmål. Slike grupper kan være for eksempel ungdom, eldre eller ulike typer brukere av kommunens tjenester. Resultatet fra slike gjestebud blir deretter kommunisert til kommunestyret som et innspill i debatten.

Poenget med innbyggermedvirkning er at innbyggerne, lokale foreninger og næringslivet ofte har verdifull informasjon og kunnskap som kan hjelpe politikerne med å utarbeide gode løsninger og treffe kloke beslutninger. De medvirkende innbyggerne er ikke nødvendigvis representative for befolkningen som sådan, men til sjuende og sist er det 
folkets representanter i form av kommunestyret som skal fatte den endelige beslutningen.

$\AA ̊$ samarbeide mer med innbyggere og lokalsamfunnets aktører skaper en mer interaktiv form for politisk lederskap der valgte politikere er i kontinuerlig dialog med sine omgivelser. I faglitteraturen argumenteres det med at denne typen lederskap kan motvirke utviklingen av mistillit til de folkevalgte. Mange forskere argumenterer også for at innbyggerne i økende grad etterspør kontakt med de folkevalgte politikerne i perioden mellom valg. Utdanningsrevolusjonen og det antiautoritære oppgjøret i 1970-årene har i alle fall gjort innbyggerne mer kompetente til å delta i politiske prosesser. Mange innbyggere ønsker derfor å være mer direkte og aktivt involvert i de politiske beslutningsprosessene, særlig når det handler om lokale forhold som påvirker deres livskvalitet.

På denne bakgrunnen er det viktig at kommunestyret diskuterer og treffer beslutning om i hvilken grad, hvor og hvordan politikerne skal utvikle politikk sammen med innbyggerne og andre lokale aktører. Det kan, som vi har poengtert ovenfor, gjøres på flere måter, og det er viktig at kommunestyret finner sin måte å gjøre det på og prøver seg frem med ulike modeller og metoder.

\section{Tema 5: Lokalmedienes bidrag til politisk lederskap}

Mens kommunen som sådan er svært synlig og allestedsnærværende for sine innbyggere, så er kommunepolitikerne ofte mindre synlige. Trolig er det få innbyggere som kan nevne andre politikere ved navn enn dem som har de mest fremskutte posisjonene i politikken. Kommunepolitikernes manglende synlighet skyldes delvis at det er vanskelig å trenge igjennom i media i løpet av valgperioden. I valgkampen er det mye oppmerksomhet på kommunepolitikerne, men når de er valgt, forsvinner ofte medienes oppmerksomhet. Spesielt liten oppmerksomhet får det rutinepregede politiske arbeidet som foregår i faste komiteer og utvalg. Det er ikke lenger noen garanti for at media rutinemessig dekker kommunestyrets møter, med mindre det er en større politisk konflikt under oppseiling.

Å være synlig som politiker og som kommunestyre er på mange måter en del av det politiske lederskapet. Det er ikke nok å lage gode politiske 
løsninger som bringer lokalsamfunnet fremover. Innbyggerne skal også høre om de nye løsningene og den retningen politikerne ønsker å ta lokalsamfunnet i. Synlighet er dessuten også viktig for at innbyggerne skal kunne holde politikerne ansvarlige for politikken de fører.

For de fleste politikere er det en selvfølge å søke synlighet gjennom lokale medier. Men mange politikere opplever en motsetning mellom den politiske lederskapslogikken og den logikken som styrer mediene. Mens det politiske lederskapet forutsetter et langt tidsperspektiv med søkelys på konkrete problemstillinger, komplekse sammenhenger og forsøk på å skape bred enighet, så retter de lokale mediene som regel oppmerksomheten mot kortsiktig handling, personspørsmål, forenklede budskap og personorienterte konflikter. Noen politikere føler at media først og fremst rapporterer om politikere som treffer raske beslutninger, som taler i store overskrifter, og som er fiendtlig innstilt overfor sine motstandere. Mange bruker derfor i økende grad sosiale medier til å forsøke å sette sin egen dagsorden utenom massemediene. Men sosiale medier kan være utfordrende med hensyn til å formidle et nyansert budskap som rekker ut over en krets av likesinnede. De bidrar heller ikke nødvendigvis til å synliggjøre politikernes lederskap som sådan.

Samspillet med media er komplisert, og trolig ligger det et stort potensial i større gjensidig forståelse mellom politikere og journalister. Politikerne trenger å forstå at de ikke kan sitte og vente på å bli «oppdaget» av journalistene - de må selv gjøre seg gjeldende. De folkevalgte trenger derfor å forstå medias og journalisters arbeidsmåte. Samtidig trenger journalister og media å ta inn over seg at politisk lederskap er komplisert, langtrukkent og noen ganger ganske kjedelig. Her kunne man tenke seg at politikerne i fellesskap - og gjerne basert på innspill fra journalister og andre medieaktører - diskuterte og utviklet en strategi som kunne sikre et mer positivt samspill med media. 


\section{Appendiks}

Tekst: Asbjørn Røiseland og Signy Irene Vabo.

\section{Datagrunnlag}

Med mindre noe annet er spesifisert i bokens kapitler, er datagrunnlaget for analysen hentet fra et forskningsprosjekt med tittelen Lokalt politisk lederskap. En sammenliknende studie av politisk lederskap blant kommunestyrerepresentanter i Norge og Danmark (POLECO). Prosjektet ble finansiert av Norges forskningsråd (prosjektnr. 254781). Det empiriske arbeidet i prosjektet omfattet en kartlegging, åtte casestudier og to spørreundersøkelser, som er nærmere omtalt nedenfor.

\section{6: Kartlegging av institusjonelle endringer/tiltak for å styrke politikernes rolle - forenklet Delphi-panel og «crowdsourcing»}

Kartlegging av lokale innovasjoner for politisk lederskap gjennom to Delphi-paneler i hvert land. Panelene bestod av cirka ti norske eller danske kommuneforskere og cirka 25 byråkrater fra nasjonalt og regionalt nivå (i Norge fra departementene og KS samt fylkesmenn). Panelene ble bedt om å identifisere norske og danske kommuner som hadde satt inn tiltak for å «styrke de folkevalgtes rolle». Forskerteamet hadde nærmere dialog med flere av medlemmene i Delphi-panelene, men panelene fikk aldri se det endelige resultatet. Det innebar at det var en sterkt forenklet versjon av Delphi-metoden som ble praktisert.

I tillegg ble det gjennomført en såkalt crowdsourcing, som i dette tilfellet innebar at prosjektteamet satte inn en annonse i Kommunal Rapport og i en tilsvarende dansk avis der vi ba aktuelle kommuner om å melde seg. Ordlyden i annonsen tilsvarte ordlyden i spørsmålet som ble stilt til Delphipanelene. Annonsen ble ledsaget av redaksjonelle oppslag (i Norge) og kronikk (i Danmark) i samme avis. I tillegg ble annonsen og oppslagene formidlet via sosiale medier, slik at budskapet skulle nå flest mulig kommuner. 


\section{7: Åtte casestudier - i fire norske og fire danske kommuner}

Prosjektteamet valgte ut åtte kommuner, fire i hvert land, for nærmere studie. Utvalget av caser ble gjort blant kommuner som var identifisert i den innledende kartleggingen, og ideen var å velge en norsk og en dansk kommune som hadde forsøkt å styrke politisk lederskap på en bestemt måte og med noenlunde tilsvarende tiltak. Oversikten over casekommunene fremgår i nedenstående tabell:

\begin{tabular}{|l|r|r|r|c|}
\hline $\begin{array}{l}\text { Type politisk } \\
\text { lederskap }\end{array}$ & Type tiltak & Kommunenavn & Befolkning & Land \\
\hline $\begin{array}{l}\text { Styrke suverent } \\
\text { politisk lederskap }\end{array}$ & $\begin{array}{r}\text { Ordfører og komitéledere med } \\
\text { forslagsrett }\end{array}$ & Fredrikstad & 81000 & NO \\
\cline { 2 - 5 } & $\begin{array}{r}\text { Gjennomgående representasjon } \\
\text { for utvalgsledere }\end{array}$ & Esbjerg & 115700 & DK \\
\hline $\begin{array}{l}\text { Styrke kollektivt } \\
\text { politisk lederskap }\end{array}$ & $\begin{array}{r}\text { Tiltak for å styrke politikernes } \\
\text { deltakelse i budsjettarbeidet }\end{array}$ & Hjartdal & 1600 & NO \\
\cline { 2 - 5 } & $\begin{array}{r}\text { Uformelle og tverrgående } \\
\text { formøter for utvalgsmedlemmer }\end{array}$ & Hedensted & 46500 & DK \\
\hline $\begin{array}{l}\text { Styrke distribuert } \\
\text { politisk lederskap }\end{array}$ & $\begin{array}{r}\text { Team av ressurspersoner for å } \\
\text { arbeide med lokale utfordringer }\end{array}$ & Steinkjer & 30000 & NO \\
\cline { 2 - 5 } & $\begin{array}{r}\text { Mobilisere innbyggerne } \\
\text { gjennom samskaping }\end{array}$ & Guldborgsund & 61200 & DK \\
\hline $\begin{array}{l}\text { Styrke interaktivt } \\
\text { politisk lederskap }\end{array}$ & $\begin{array}{r}\text { Oppgaveutvalg med politikere } \\
\text { og innbyggere }\end{array}$ & Svelvik & 6400 & NO \\
\cline { 2 - 5 } & $\begin{array}{r}\text { Oppgaveutvalg med politikere } \\
\text { og innbyggere }\end{array}$ & Gentofte & 74500 & DK \\
\hline
\end{tabular}

Det ble foretatt en rekke intervjuer med politikere og administrative ledere i de åtte kommunene. Der det var mulig, var medlemmer av prosjektteamet også observatører på møter i kommunestyret og i andre politiske organer. Selv om det empiriske arbeidet ble organisert slik at danske og norske forskere hadde hovedansvar for casestudien i sine respektive land, prioriterte prosjektteamet at forskerne, så langt det var mulig, skulle krysse landegrensene i det empiriske arbeidet. Det medførte at i om lag halvparten av tilfellene gjennomførte norske forskere intervjuer i Danmark, og danske forskere gjennomførte intervjuer i Norge. 
Intervjuene fulgte en semistrukturert guide. Intervjuene ble i ettertid transkribert, og alle intervjuer har stått til disposisjon for alle deltakerne i prosjektet.

\section{8: Spørreundersøkelse til alle politikere i Norge og Danmark}

Spørreundersøkelsen gikk til samtlige kommunestyrepolitikere i Norge og Danmark. Den norske svarprosenten var på 40 prosent, mens den danske undersøkelsen oppnådde 29 prosent.

I Norge ble undersøkelsen gjennomført i samarbeid med et forskningsprosjekt som evaluerte den norske kommunereformen. Undersøkelsen er dokumentert i Dokumentasjonsrapport for spørjeundersøkinga knytt til kommunereforma og POLECO (Bjarte Folkestad, Uni Research, 2018).

Den danske spørreskjemaundersøkelsen er dokumentert i Dokumentasjonsrapport for spørreundersøkelsen om politisk lederskap, POLECO (Marte Winsvold, ISV, 2020).

\section{8: Kartleggingsundersøkelse til kommunene om institusjonelle endringer/tiltak for å styrke politikernes rolle}

Formålet med denne kartleggingsundersøkelsen var å finne ut hvor mange kommuner som hadde gjennomført ulike typer tiltak for å styrke politisk lederskap. Hver kommune i Norge og Danmark mottok et spørreskjema som ble sendt til Politisk sekretariat. Undersøkelsen var lagt opp på enklest mulig måte, med kun ja- og nei-spørsmål. 67 prosent av kommunene i Danmark svarte på undersøkelsen, mens svarprosenten i Norge var 72 prosent. 


\section{Forfatterbiografier}

Asbjørn Røiseland er professor i statsvitenskap ved Nord universitet og OsloMet - storbyuniversitetet. Han forsker på nettverksstyring og samskaping og retter spesiell oppmerksomhet på demokrati og politisk lederskap.

Signy Irene Vabo er professor i statsvitenskap ved Universitetet i Oslo. Hun forsker på offentlig styring, nettverksstyring, politisk organisering, politisk lederskap og lokalt demokrati.

Tina Øllgaard Bentzen er lektor ved Roskilde universitet i Danmark. Hun forsker på politisk styring, tillit og offentlig administrasjon.

Espen Leirset er universitetslektor og doktorgradsstipendiat ved Nord universitet. Han forsker på lokalpolitiske prosesser, betydningen av åpenhet og hvordan politikk og presse påvirker hverandre.

Christian Lo er førsteamanuensis ved Nord universitet og seniorforsker ved Nordlandsforskning. Lo har i sin forskning benyttet etnografiske innfallsvinkler til å forstå lokalpolitisk lederskap, byråkrati, politisk kultur og utviklinger innen ulike deler av velferdstjenestene.

Eva Sørensen er professor i offentlig administrasjon og demokrati ved Roskilde universitet i Danmark og professor II ved Nord universitet. Hun forsker på nye demokrati- og styringsformer, med særlig oppmerksomhet på politikernes rolle.

Jacob Torfing er professor i politikk og offentlige institusjoner ved Roskilde universitet i Danmark og professor II ved Nord universitet. Han forsker på nettverksstyring, samskaping, innbyggermedvirkning og demokrati.

Marte Winsvold er postdoktor ved Universitetet i Oslo og seniorforsker ved Institutt for samfunnsforskning. Hun forsker blant annet på politisk deltakelse mellom valg, politisk tillit og betingelsene for politisk styring. 